\title{
Airlift Recirculation Well Final Report - Southern Sector
}

by

R. M. White

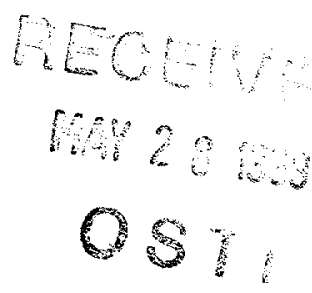

Westinghouse Savannah River Company

Savannah River Site

Aiken, South Carolina 29808

DOE Contract No. DE-AC09-96SR18500

This paper was prepared in connection with work done under the above contract number with the U.S. Department of Energy. By acceptance of this paper, the publisher and/or recipient acknowledges the U.S. Government's right to retain a nonexclusive, royalty-free license in and to any copyright covering this paper, along with the right to reproduce and to authorize others to reproduce all or part of the copyrighted paper. 


\section{AIRLIFT RECIRCULATION WELL}

\section{FINAL REPORT - SOUTHERN SECTOR (U)}

\section{R.M. White}

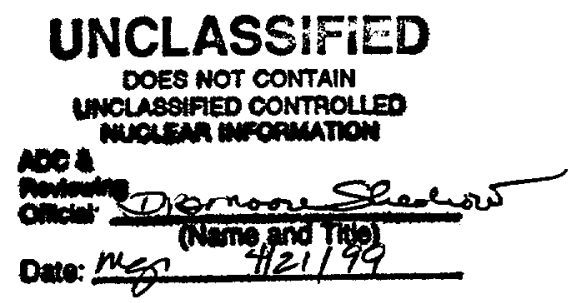

Westinghouse Savannah River Company Savannah River Site Aiken, SC 29808

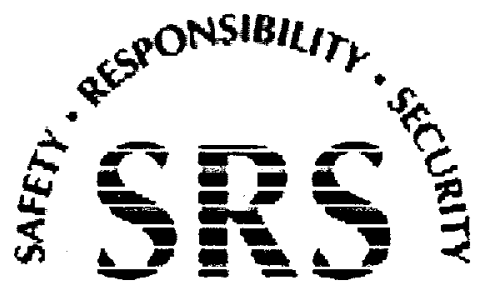




\section{DISCLAIMER}

This report was prepared as an account of work sponsored by an agency of the United States Government. Neither the United States Government nor any agency thereof, nor any of their employees, makes any warranty, express or implied, or assumes any legal liability or responsibility for the accuracy, completeness, or usefulness of any information, apparatus, product, or process disclosed, or represents that its use would not infringe privately owned rights. Reference herein to any specific commercial product, process, or service by trade name, trademark, manufacturer, or otherwise does not necessarily constitute or imply its endorsement, recommendation, or favoring by the United States Government or any agency thereof. The views and opinions of authors expressed herein do not necessarily state or reflect those of the United States Government or any agency thereof.

This report has been reproduced directly from the best available copy.

Available to DOE and DOE contractors from the Office of Scientific and Technical Information, P.O. Box 62, Oak Ridge, TN 37831; prices available from (615) 576-8401.

Available to the public from the National Technical Information Service, U.S. Department of Commerce; 5285 Port Royal Road, Springfield, VA 22161. 


\section{DISCLAIMER}

Portions of this document may be illegible in electronic image products. Images are produced from the best available original document. 


\section{AIRLIFT RECIRCULATION WELL}

FINAL REPORT - SOUTHERN SECTOR (U)

R.M. White

Publication Date: March 1999

Westinghouse Savannah River Company Savannah River Site

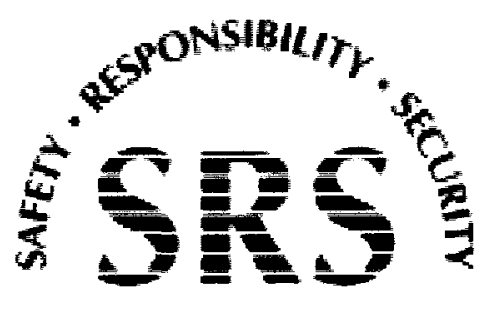

Aiken, SC 29808 


\section{AIRLIFT RECIRCULATION WELL FINAL REPORT - SOUTHERN SECTOR}

Authentication and Approvals:

R. M. White, Author

Date

J. G. Sonnenberg, Manager, ERTS

Date 


\begin{abstract}
Chlorinated solvents used in the A/M-Area at the Savannah River Site (SRS) from 1952 1982 have contaminated the groundwater under the site. Trichloroethylene (TCE) and perchloroethylene (PCE) have migrated downward through the water table and into an underlying confined aquifer; the Lost Lake aquifer. The various source locations and the complex hydrology and geology underlying the $\mathrm{A} / \mathrm{M}$ Area have resulted in a complex contaminant plume that is advancing along several fronts. Portions of the plume are migrating towards a natural seepline in the vicinity of Tim's Branch, a tributary of the Savannah River. To comply with the requirements of the current SCDHEC Part B Permit, this plume is being addressed by a multi-phase program under the direction of the Environmental Restoration Division (ERD) at SRS. This report details the first phase of this program, the containment of the portion of the plume greater than $500 \mathrm{ppb}$ (TCE) within the Southern Sector of the A/M Area.
\end{abstract}

Airlift Recirculation Well technology was selected to intercept the leading edge of the contaminant plume in the Southern Sector of the A/M Area. The Airlift Recirculation Well (ARW) is a new and innovative technology with potential for more cost effective implementation than conventional pump and treat systems. Two Airlift Recirculation Wells have been installed and tested (from Dec. 1996 to March 1999) to establish the feasibility of the technology and to quantify performance parameters needed to locate a line of these wells along the leading edge of the contaminant plume. The wells proved to be very sensitive to proper development, but after this requirement was met, performance was very good.

Key design parameters were established to allow the installation of a row of recirculation wells that will intercept and treat the contaminant plume. The initial in-well stripping efficiency was determined to be approximately $60 \%$. A technology enhancement, the Multi-Stage In-Well Aerator (MIA) was identified and deployed. Initial testing indicates that the MIA can achieve in-well stripping efficiencies of $80-90 \%$ and perhaps higher.

The installation of the remaining wells in the treatment system will be completed and placed in service in 1999. Additional applications of this technology are under consideration for the Western Sector of the A/M-Area and at the Miscellaneous Chemical Basin. 


\section{Contents}

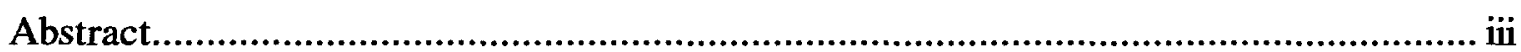

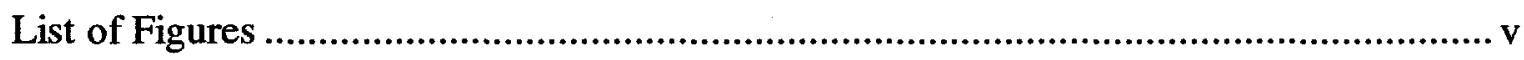

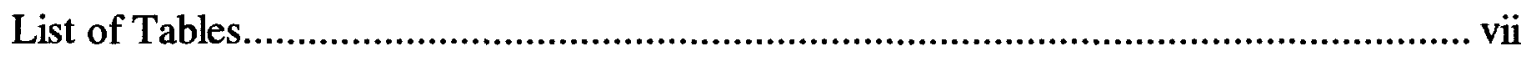

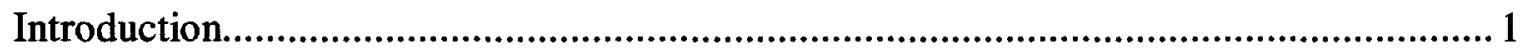

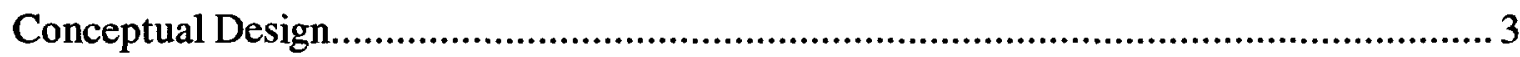

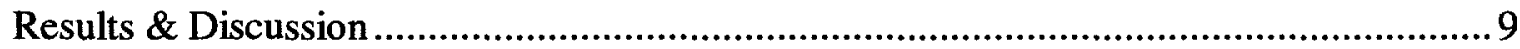

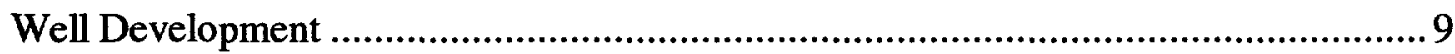

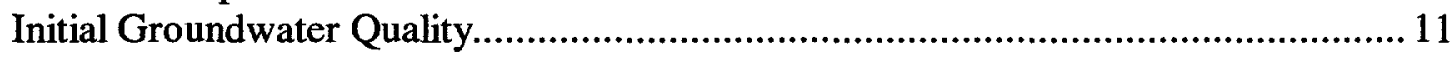

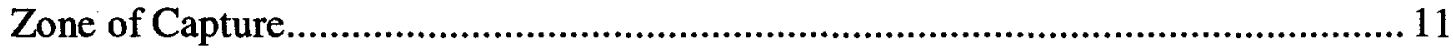

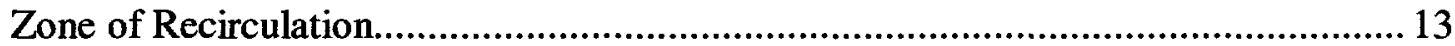

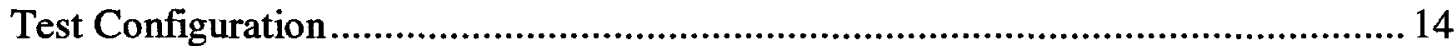

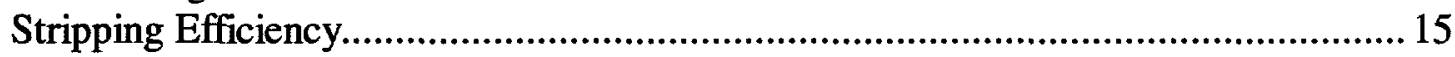

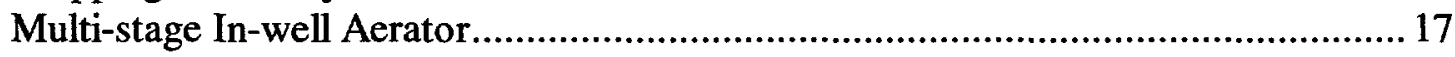

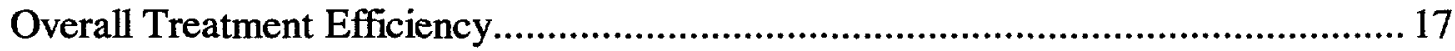

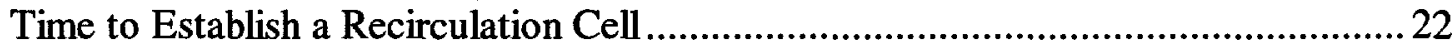

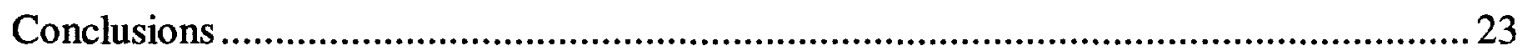

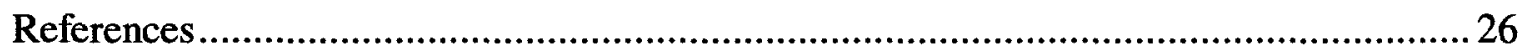

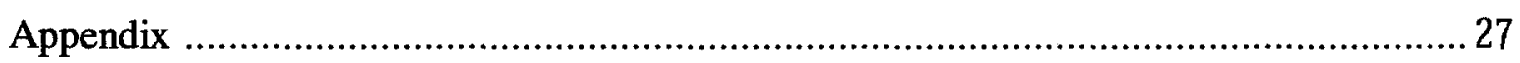




\section{List of Figures}

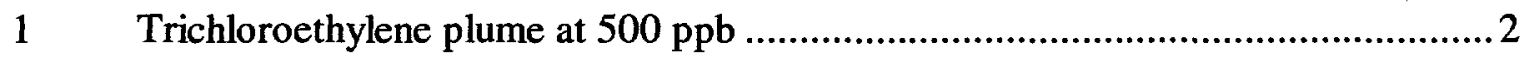

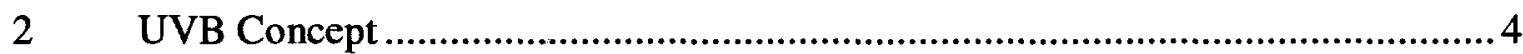

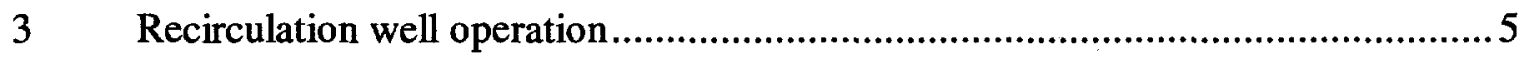

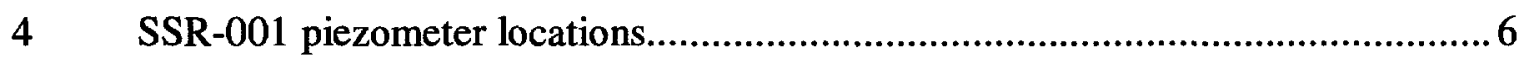

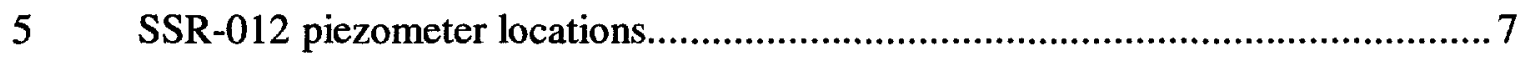

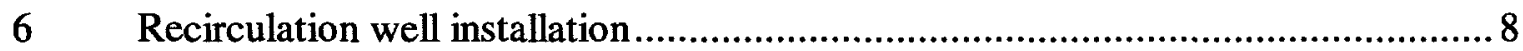

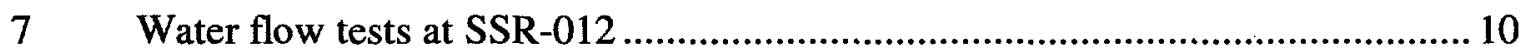

$8 \quad$ Potentiometric heads at lateral piezometers ………........................................ 12

$9 \quad$ Simulated groundwater flow patterns ……........................................................ 13

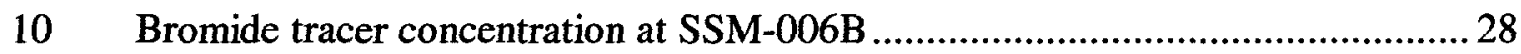

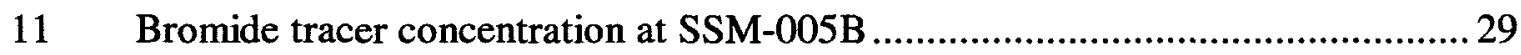

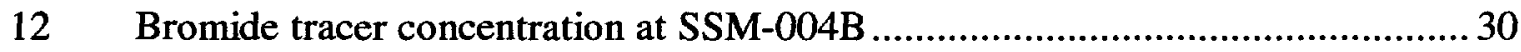

13 Bromide tracer concentration at SSM-004C ………........................................

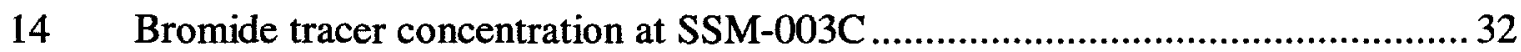

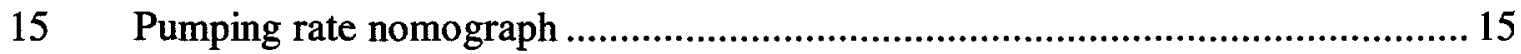

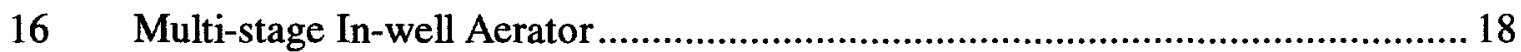

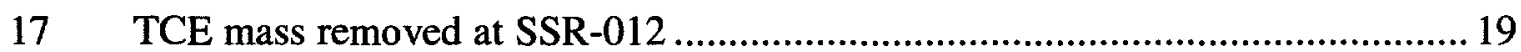

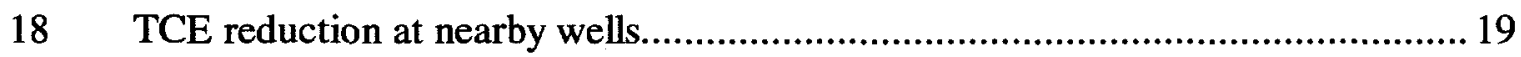

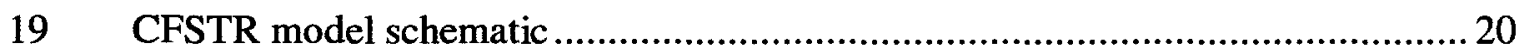

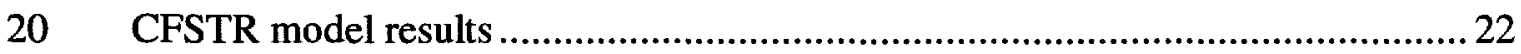

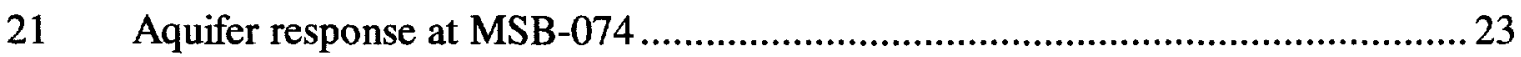

$228,000 \mathrm{ppb}$ Isocontours near SSR-012 with the well in service ............................2 24

$238,000 \mathrm{ppb}$ Isocontours near SSR-012 with the well out of service.........................25

24 Groundwater sample analytical results - SSM-001 .............................................. 33 
25 Groundwater sample analytical results - SSM-002 ................................... 34

26 Groundwater sample analytical results - SSM-003 ..................................... 35

27 Groundwater sample analytical results - SSM-004 ................................... 36

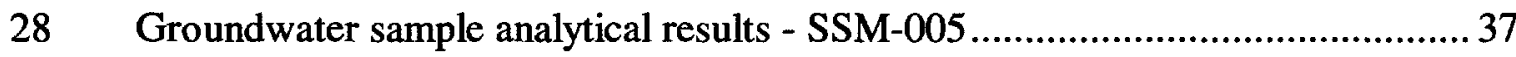

29 Groundwater sample analytical results - SSM-006.................................... 38

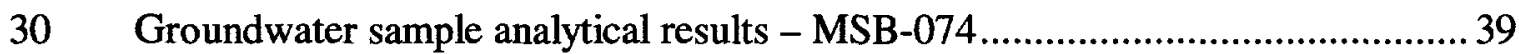

31 Groundwater sample analytical results - SSM-007.................................... 40

32 Groundwater sample analytical results - SSM-008................................. 41

33 Groundwater sample analytical results - SSM-009................................. 42

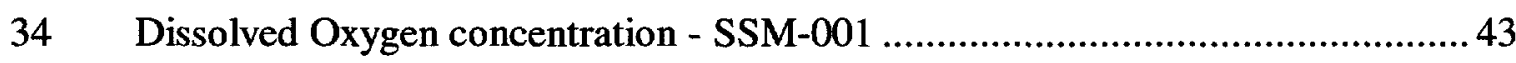

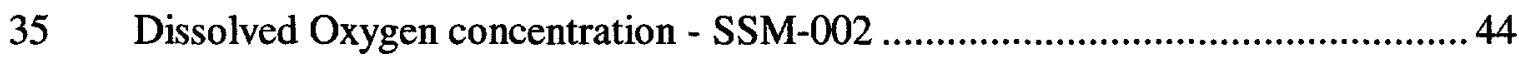

36 Dissolved Oxygen concentration - SSM-003 ........................................ 45

37 Dissolved Oxygen concentration - SSM-004 ......................................... 46

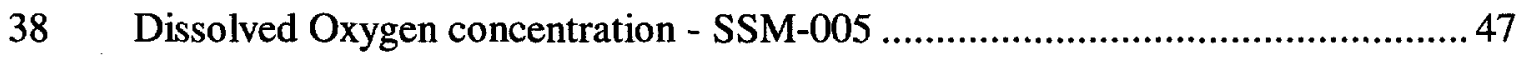

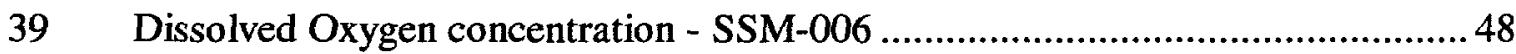

40 Dissolved Oxygen concentration - MSB-074 ........................................ 49

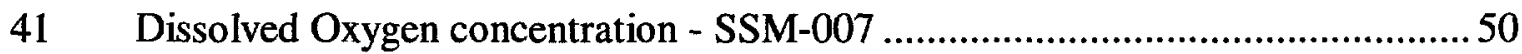

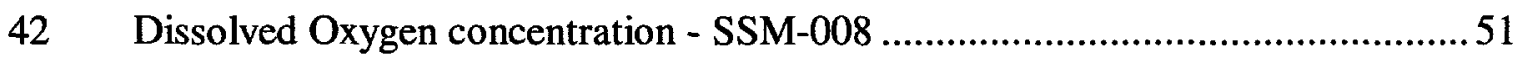

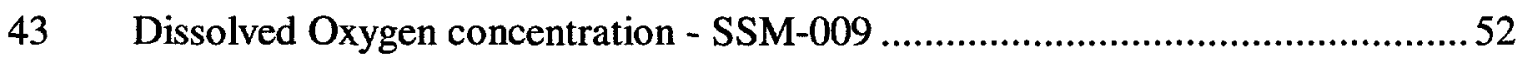




\section{List of Tables}

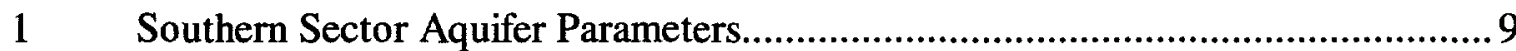

$2 \quad$ Tracer travel time

$3 \quad$ Typical operating parameters @ SSR-012 ............................................................... 13

$4 \quad$ Results of groundwater sampling Wells SSM-001 and $002 \ldots \ldots \ldots \ldots \ldots \ldots \ldots \ldots \ldots \ldots \ldots . . . .53$

$5 \quad$ Results of groundwater sampling Wells SSM-003 and 004 …............................54

6 Results of groundwater sampling Wells MSB-074 and SSM-005 .........................55

$7 \quad$ Results of groundwater sampling Wells SSM-006 and 007 ..................................56

$8 \quad$ Results of groundwater sampling Wells SSM-008 and 009 ….............................56

$9 \quad$ Results of exhaust air sampling - SSR-012 …................................................57 


\section{Introduction}

Metal finishing operations at the Savannah River Site (SRS) A/M-Area utilized chlorinated solvents for degreasing and cleaning activities from the 1950's to the 1980's. From 1952 to 1982 an estimated 13 million pounds of chlorinated solvents, primarily trichloroethylene (TCE) and perchloroethylene (PCE), were used in the M-Area. Much of this solvent evaporated during use but residual solvent was discharged to a process sewer system. Approximately two million pounds of solvent are estimated to have been released to the M-Area Settling Basin. Another one and one-half million pounds was released to the A-014 outfall.

TCE and PCE were first identified in the local groundwater in 1981. Pump and treat technology was initiated in 1983 and continues today. Hazardous materials in the M-Area Settling Basin have been stabilized and the basin has been capped and closed. The TCE and PCE plumes in the groundwater are in the process of characterization and continue to be monitored. The M-Area RCRA Part B permit allows implementation of innovative technologies for the characterization and treatment of dissolved DNAPL (Dense Non-Aqueous Phase Liquid) plumes and soil contamination in the $\mathrm{A} / \mathrm{M}$-Areas.

The groundwater plume has moved downward into a confined aquifer (the Lost Lake aquifer) and is continuing generally southward into the southern part of the A/M-Area (the Southern Sector). The Southern Sector is undeveloped and heavily forested. The Part B Permit Application for the Southern Sector of the A/M Area requires the TCE plume to be hydraulically controlled at the $500 \mathrm{ppb}$ isoconcentration location. Airlift Recirculation Well (ARW) technology was chosen for use in this area because of its technical potential and because it treats the groundwater without bringing it to the surface. This eliminates the need to create and permit an outfall for the treated water discharge, thereby reducing costs and the risk of personnel exposure to listed contaminants. Recirculation wells also improve conditions for natural bioremediation by maintaining or increasing levels of dissolved oxygen in the aquifer.

An areal view of the A/M Area of the Savannah River Site is presented on Figure 1. The $\mathrm{A} / \mathrm{M}$ Area has been divided into sectors, based roughly upon location relative to the central part of the area. Quarterly monitoring well data and depth discrete soil headspace data from soil borings was used to estimate the location of the leading edge of the $500 \mathrm{ppb}$ isoconcentration contour of the TCE plume. This plume is shown on Figure 1. The configuration of the TCE plume in the Lost Lake aquifer consists of two primary components within the Southern Sector. A larger lobe was estimated to extend along a half-mile front from the vicinity of monitoring well MSB-040 to monitoring well MSB-074. A narrower plume appears to follow Tim's Branch, a tributary of the Upper Three Runs Creek, and a receptor of discharges from the A-014 Outfall. 


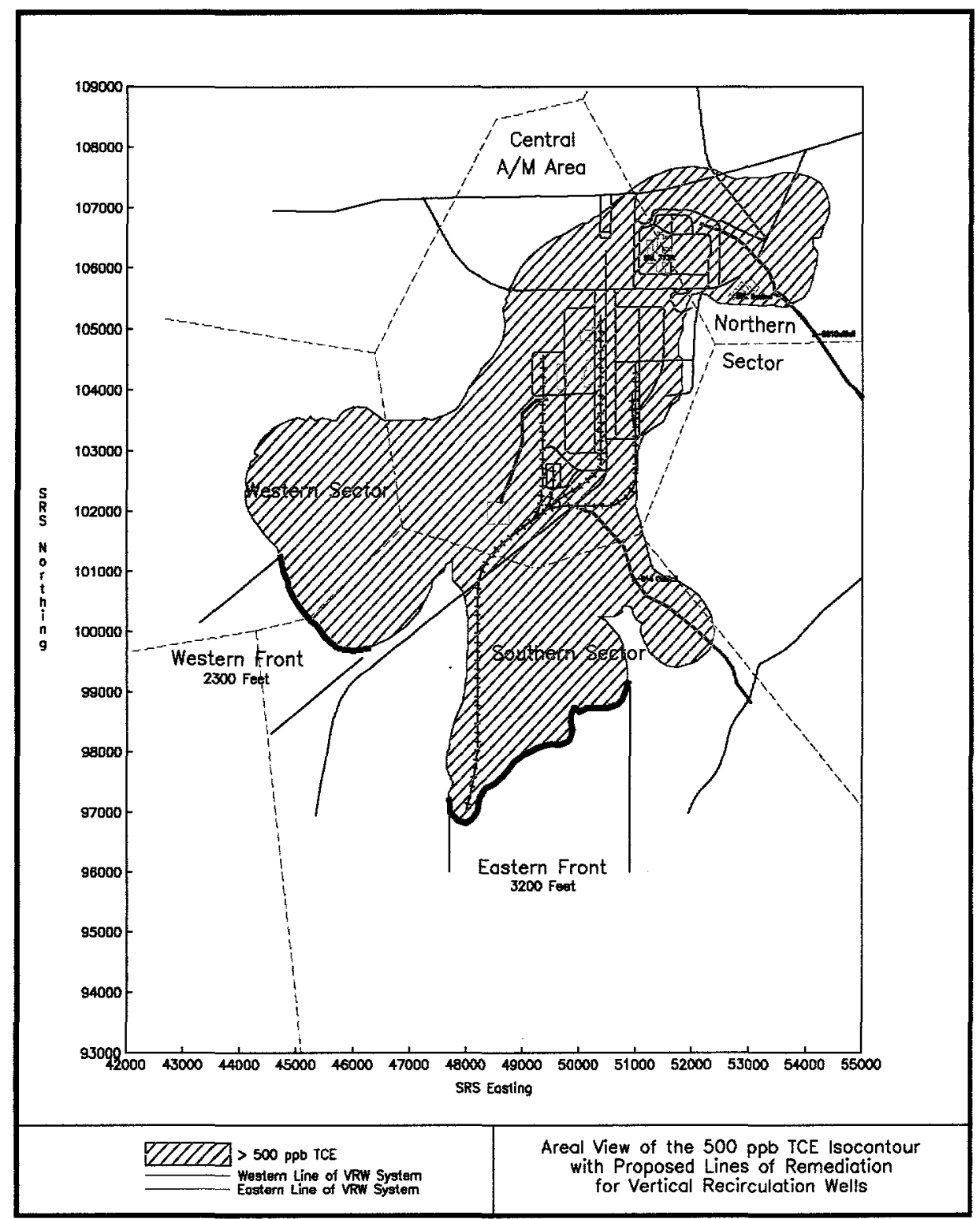

Figure 1: Trichloroethylene plume at 500 ppb

The objective of this study was to install and to test two airlift recirculation wells (one at each end of the broader lobe of the plume; i.e. the Eastern Front) and to determine the following information:

- the size of the area under the hydraulic control of the recirculation well (the Zone of Capture or ZOC); 
- the size of the area in which treated water is recaptured for another pass through the recirculation well (the Zone of Recirculation or ZOR);

- the in-well vapor stripping efficiency of the wells;

- the overall treatment efficiency of the wells relative to the contaminated plume;

- the length of time necessary to establish the recirculation well Zone of Capture;

- the feasibility of using recirculation well technology to control the contaminant plume at the $500 \mathrm{ppb}$ isoconcentration line;

- the appropriate well spacing along the Eastern Front for effective plume control;

- operating data necessary for preparation of the revised Corrective Action Engineering Report and associated permits for this area.

The initial results from this work are described in a progress report (Airlift Recirculation Well Test Results - Southern Sector, WSRC-TR-97-00246). Problems with temporary utility services, well development, and higher than expected contaminant levels in the eastern part of the site resulted in the bulk of the effort being directed towards one well, SSR-012.

\section{Conceptual Design}

Much of the fundamental research concerning recirculation wells can be traced to the work of Herrling and Stamm in developing the GZB concept. The GZB (Grunwasser Zirkulations Brunnen or groundwater circulation wells) concept is a generalization of the UVB concept. The UVB (Unterdruck Verdampfer Brunnen or vacuum vaporizer wells) concept utilizes a motor driven pump to circulate groundwater and a vacuum system to aerate the water to remove volatile contaminants. See Figure 2.

The Airlift Recirculation Well is, first of all, an in-well vapor stripping system. Additionally, these wells set up a recirculation zone within the aquifer. Air injected near the bottom of the airlift pump (see Figure 3) rises toward the surface creating a column of air and water. The air/water mixture, being lighter than the water in the surrounding saturated zone, is pushed upward. As the air/water mixture passes through the pump, volatile contaminants are stripped from the water and are discharged with the air.

As groundwater is pumped from the bottom of the aquifer and reintroduced at the top of the aquifer a circulating flow of water is created. Depending upon the natural flow patterns present, the recirculating groundwater may pass through the well a number of times before slipping downgradient. 


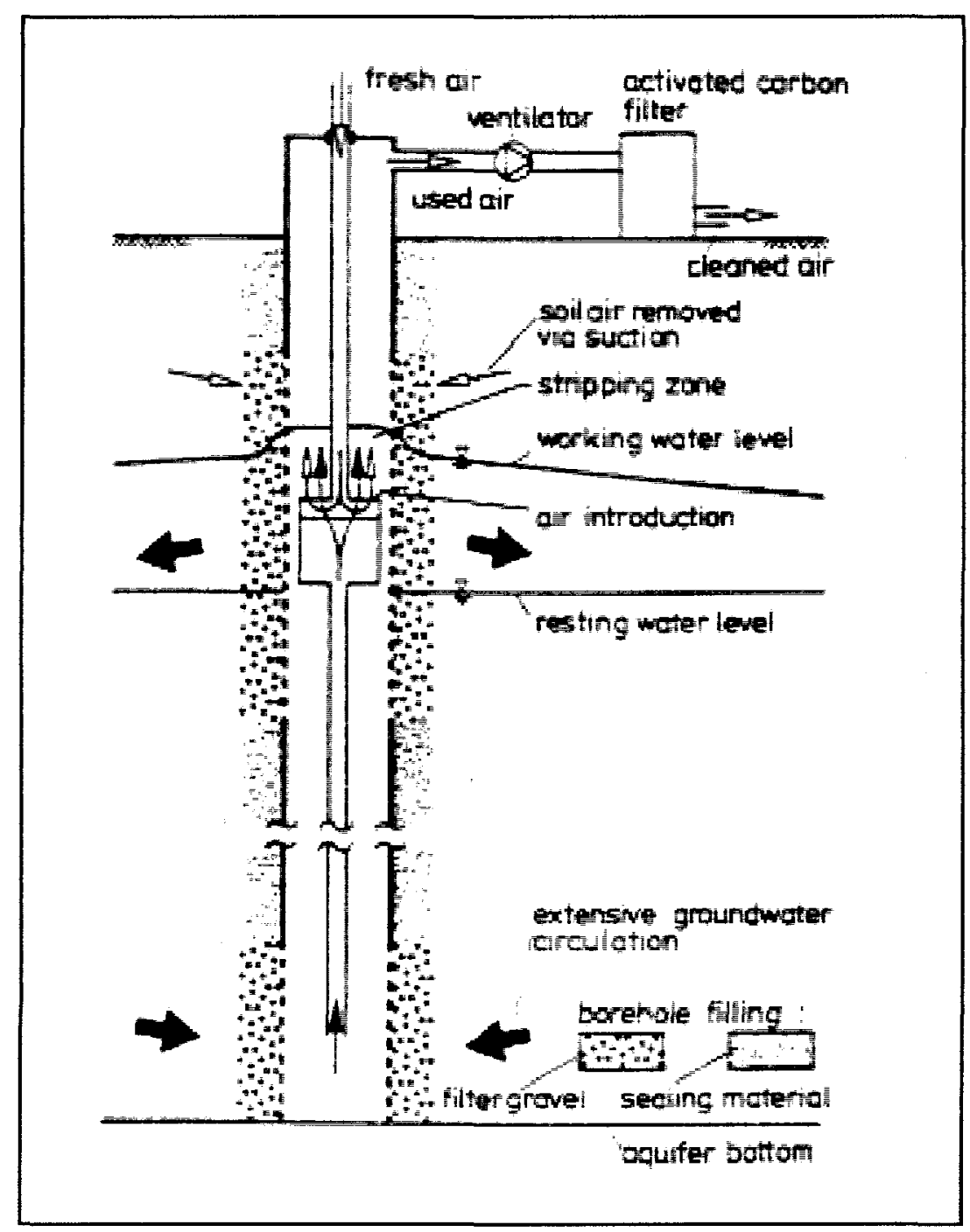

Figure 2: UVB concept

Early UVB research led to the development of various distinct systems for in-well vapor stripping. In the United States, the ARW concept was developed by Gorelick \& Gvirtzman (the NoVOC's concept) and by Pennington (the Density Driven Convection concept). The ARW utilizes airlift pumping and direct air injection for the in-well pumping and stripping actions rather than vacuum and a pinhole plate as is used in the UVB. All of these technologies, however, are intended to create the same recirculating flow of groundwater in the aquifer. Consequently, Herrling's original analysis of groundwater flow and recirculation cell development is still applicable.

Our first two well locations were selected to be just downgradient of the projected $500 \mathrm{ppb}$ isoconcentration contour at each end of the Eastern Front. This established the two ends of a proposed line of recirculation wells intended to capture and treat this plume front. 


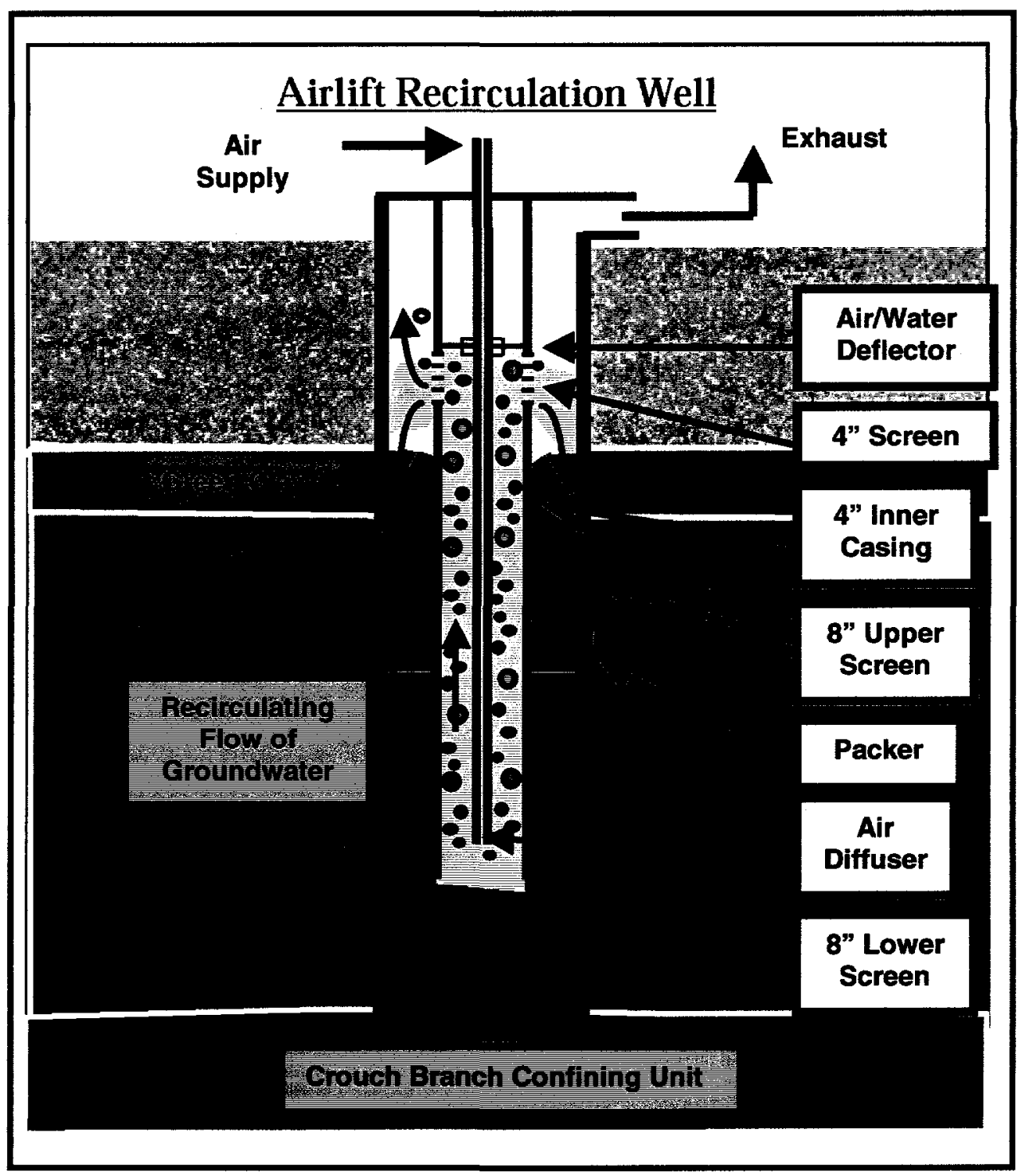

Figure 3: Recirculation well operation

Herrling's approach was used to estimate the number of recirculation wells required to capture the plume front at various pumping rates. For a flow range of $5-80 \mathrm{gpm}$, the number of wells required was estimated to be from $5-13$. Twelve was felt to be a conservative number, however rather than committing immediately to a fixed number of wells, two initial sites were chosen; one at each end of the Eastern Front. This would allow the ARW concept to be tested to confirm the proper well spacing necessary before committing the resources needed for a full suite of wells. Twelve wells would result in a uniform well spacing of 252 feet. The first two wells were designated SSR-001 and SSR-012. These two wells were completed near the end of 1996. 


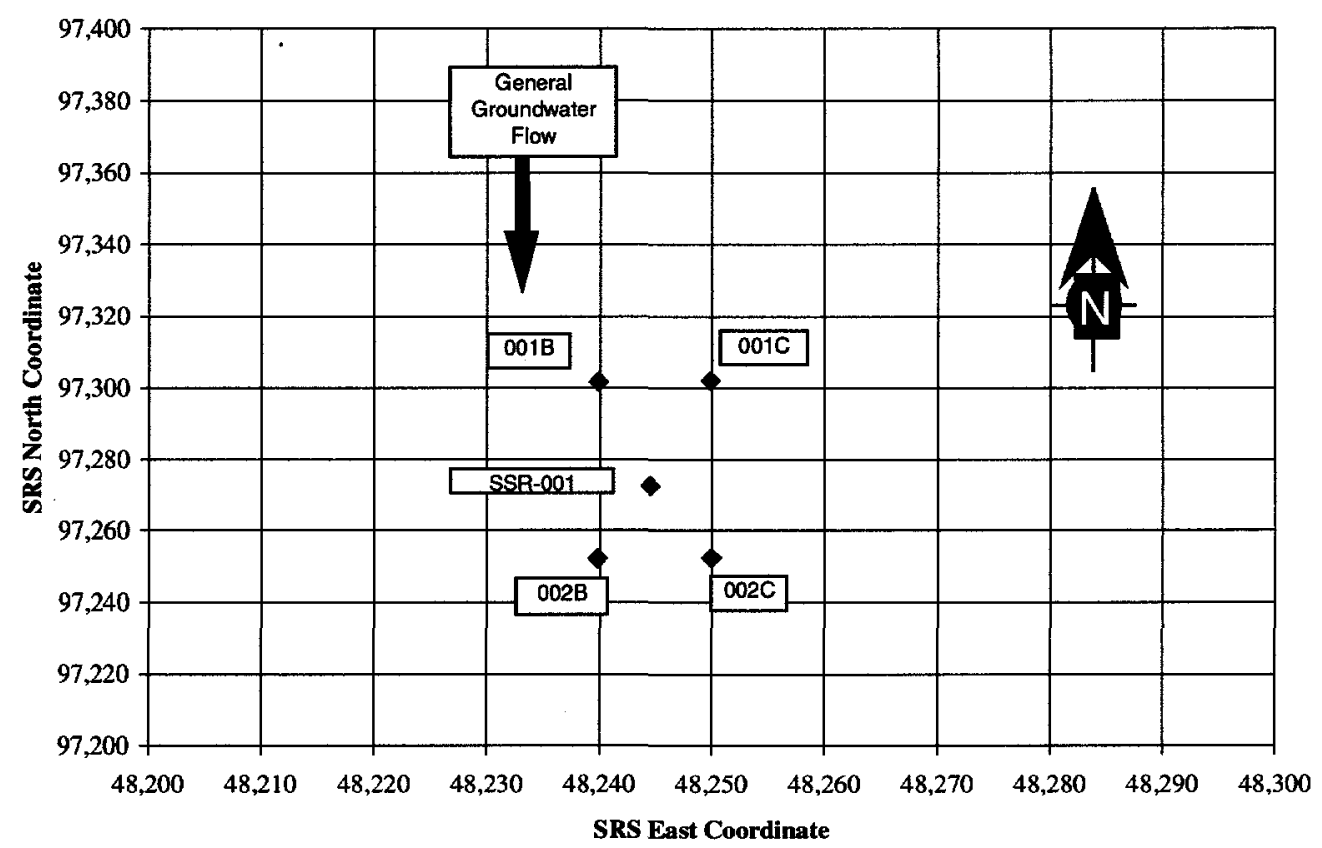

\section{Figure 4: SSR-001 Piezometer locations}

A piezometer cluster was located upgradient and downgradient of each recirculation well for observing groundwater levels and for groundwater sampling. Each cluster consisted of one 2 inch PVC casing screened in the top of the Lost Lake aquifer (the " $\mathrm{C}$ " well) and one 2 inch PVC casing screened in the bottom of the Lost Lake aquifer (the " $\mathrm{B}$ " well). The piezometers were spaced on 10 feet lateral centers. The upgradient piezometer cluster at well SSR-001 was located 30 feet from the recirculation well and the downgradient piezometer cluster was located 20 feet from the recirculation well (reference Figure 4).

The piezometer clusters at well SSR-012 were spaced equally, 20 feet upgradient and 20 feet downgradient (reference Figure 5). The different upgradient spacing was simply to provide an additional point of reference for the data. In July 1997 three well clusters (SSM-005, SSM-006, and SSM-007) were added to the east of SSR-012. These wells were spaced to provide a uniformly spaced series of wells lateral to the natural groundwater flow for use in quantifying the Zone of Capture. In December 1997 two additional well clusters (SSM-008 and SSM-009) were added between SSR-011 and SSR-012. These wells were added to better evaluate the combined effect of running two adjacent recirculation wells. 


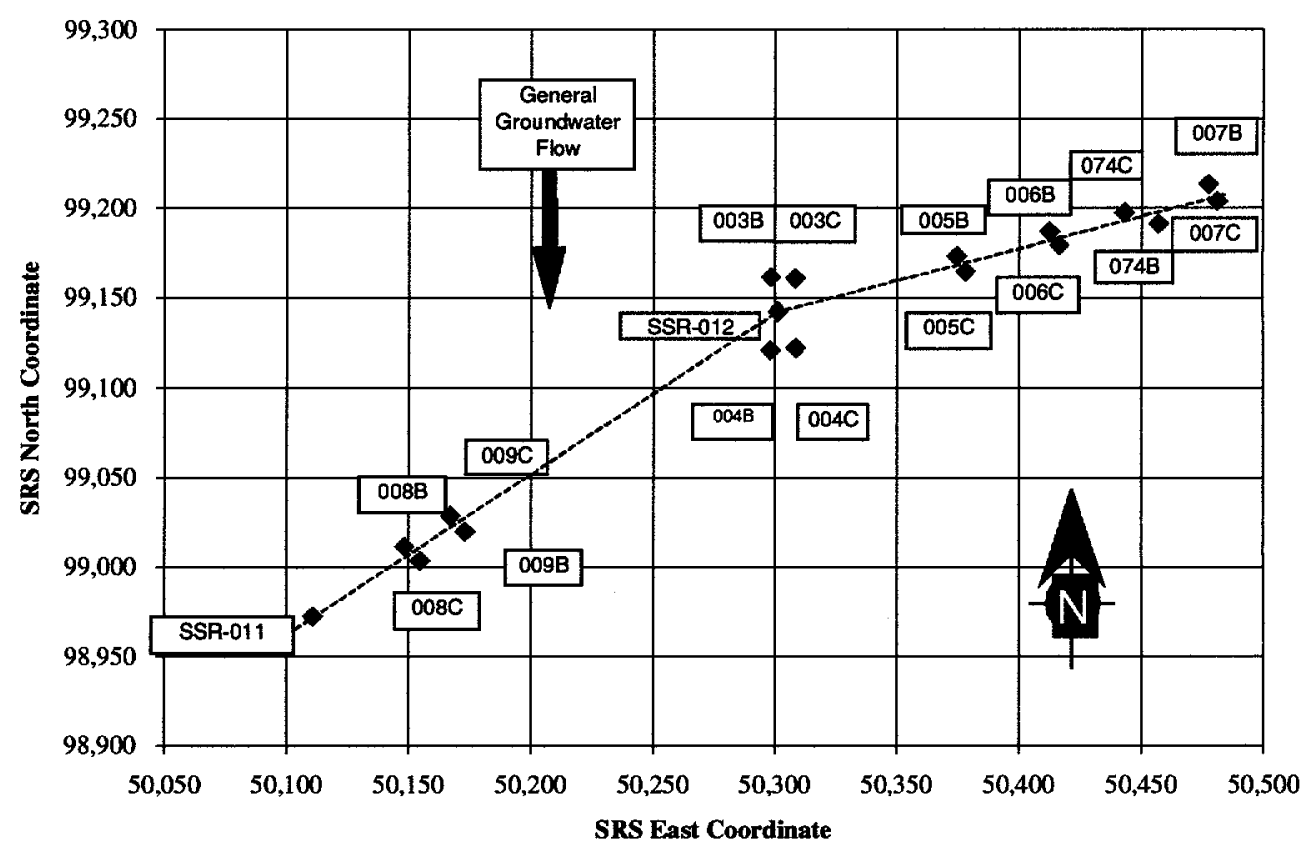

\section{Figure 5: SSR-012 piezometer locations}

The recirculation well consists of an 8 inch schedule 80 PVC well casing with two separate ten foot long screen zones; one at the top of the aquifer and one at the bottom of the aquifer (reference Figure 6). The PVC screens have 0.020 inch machined slots on a $1 / 8$ inch spacing. The casing was grouted in place with gravel pack at each screen and a bentonite seal between the screens. An airlift pump was constructed from 4 inch schedule 40 PVC well casing and a 1 inch schedule 80 PVC airline. The 4 inch casing was installed inside the 8 inch casing with an inflatable packer to isolate the annulus between the two 8 inch screen zones. The bottom of the 4 inch cassing (pump inlet) was placed just above the 8 inch screen at the bottom of the aquifer. A five foot long screen was placed in the 4 inch casing such that the bottom of the screen was eight feet above the potentiometric head in the top of the aquifer. This is the airlift pump outlet. The 1 inch air line was installed in the 4 inch well casing with a discharge diffuser located seven feet above the bottom of the 4 inch casing. The air diffuser was fabricated by drilling $76-5 / 32$ inch diameter holes in a 12 inch long piece of 1 inch schedule 80 PVC pipe. The intent was to create relatively small bubbles discharging laterally while minimizing backpressure on the air line and the risk of plugging the diffuser with dirt, bacterial growth, etc. 


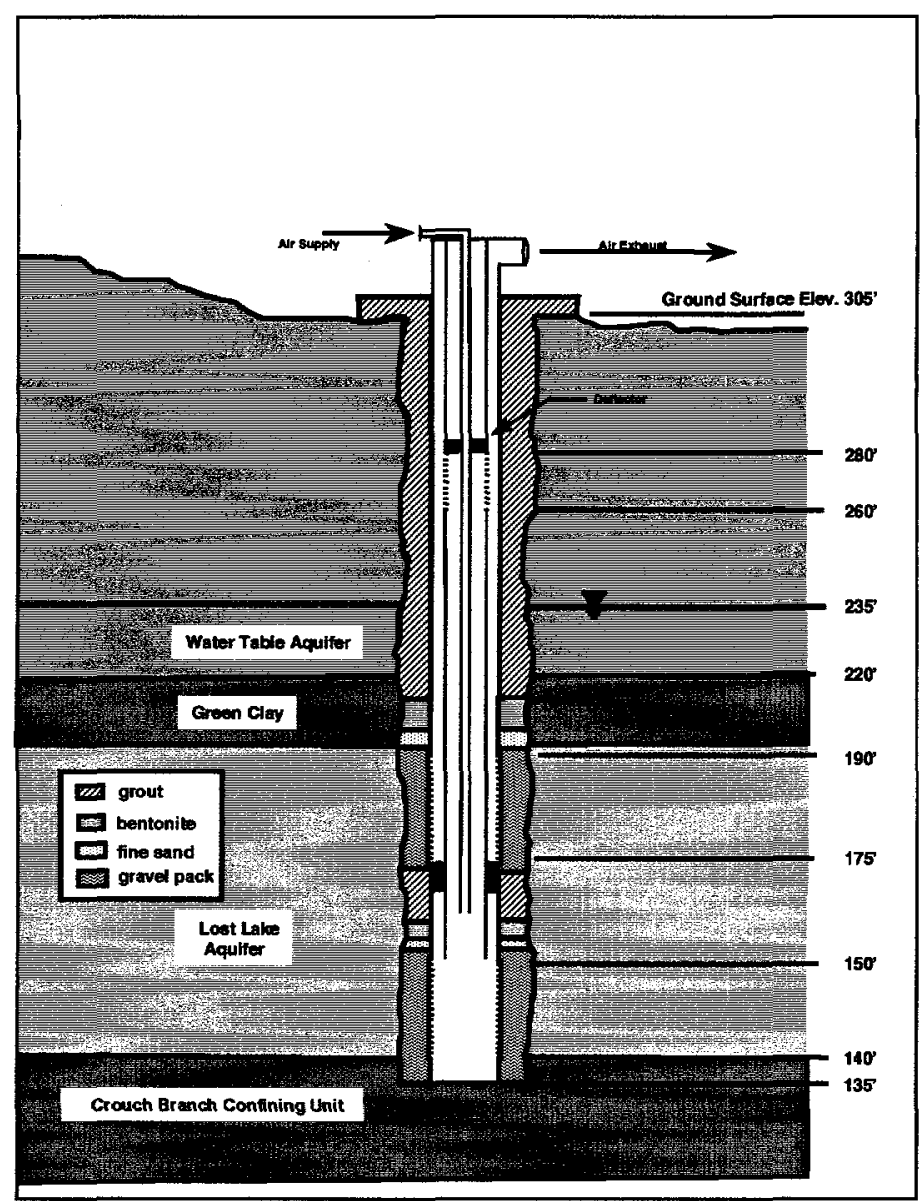

\section{Figure 6: Recirculation well installation}

A duplex, oil-free air compressor package was installed at each recirculation well to provide compressed air. The compressor package was rated at $110 \mathrm{cfm}$ at $125 \mathrm{psi}$. Because of the remote location of the recirculation wells, initially there were no utilities available. To expedite testing of the wells, portable generators were installed at each well site. The installation of permanent power was completed in December 1997.

Typical aquifer properties are listed in Table 1. Aquifer thickness, grain size, soil type, and porosity were derived from drill cuttings, core analysis and borehole logs from the recirculation wells and from earlier borings in the vicinity. Measurements from the upper and lower observation wells during pump tests allowed the calculation of hydraulic conductivity. The anisotropic ratio is simply the ratio of horizontal hydraulic conductivity to vertical hydraulic conductivity. The potentiometric gradient was measured at the observation wells and was used with the conductivity, aquifer thickness and porosity to calculate pore velocity. Transmissivity is the product of horizontal hydraulic conductivity and aquifer thickness. 
Table 1: Southern Sector Aquifer Parameters

\begin{tabular}{|l|c|}
\hline \multicolumn{1}{|c|}{ Parameter } & Value \\
\hline Aquifer thickness & $54 \mathrm{ft}$. \\
\hline Grain size & $\begin{array}{c}\text { V. fine to v. coarse sand, predominantly fine } \\
\text { to medium }\end{array}$ \\
\hline Sediment type & sub-mature quartz sand \\
\hline Porosity & $0.15-0.25$ \\
\hline Horizontal hydraulic conductivity & $25.8 \mathrm{ft} / \mathrm{day}$ \\
\hline Vertical hydraulic conductivity & $1.43 \mathrm{ft} / \mathrm{day}$ \\
\hline Anisotropic ratio & 18 \\
\hline Horizontal pore velocity & $0.19 \mathrm{ft} / \mathrm{day}$ \\
\hline Transmissivity & $1393 \mathrm{ft} / \mathrm{day}$ \\
\hline
\end{tabular}

Grundfos sample pumps were used to take water samples from the observation wells for analysis. Water samples were analyzed for TCE and PCE concentrations using a gas chromatograph with a headspace analyzer (EPA SW-846 method 8260A). Results are included in the Appendix (Figures $24-43$ and Tables $4-8$ ). Dissolved oxygen (D.O.) and specific conductivity measurements were made with a YSI analyzer.

Gas samples were taken from the air supply line and from the exhaust stack at each recirculation well and analyzed for TCE and PCE concentrations by direct injection into a gas chromatograph (EPA SW-846 method 5021). Results are tabulated in Table 9 in the Appendix.

\section{Results and Discussion}

\section{Well Development}

Initial results demonstrated the sensitivity of the recirculation well technology to proper well development. Special efforts must be made to aggressively develop both the upper and lower screens zones independently. In our case the wells were installed with conventional mud rotary drilling techniques as this is the most practical method at SRS. We were not able to achieve effective well operation until all residual drilling mud and loose fines were removed from both screen zones. This was successfully accomplished at SSR-012 using airlift and pump and swab techniques. However to date, we have not realized the full potential of SSR-001. This information 
is covered in detail in the earlier progress report (Airlift Recirculation Well Test Results Southern Sector, WSRC-TR-97-00246). The use of innovative development techniques are being planned to resolve this situation. Alternative well drilling methods that do not rely on drilling muds will be considered for future wells. This report will focus upon results achieved at SSR-012.

Since the functionality of the recirculation well depends in large part upon the amount of water that can pass through the well, a major concern is the susceptibility of the upper screen to plugging with clays and fines from the pumped water. To gauge this we performed a flow test in August 1998, and compared the results with those from a similar test in May 1997. This test involved operating the well at a high flow rate with a level transducer located in the annular space above the upper 8 inch screen. The air supply to the well is shut off and the change in the water level in the annulus is recorded. This provides a direct measurement of the water flow out of the upper screen. As can be seen in Figure 7, although the flow rate had declined marginally, a significantly higher head was required to maintain this flow. This indicates that the upper

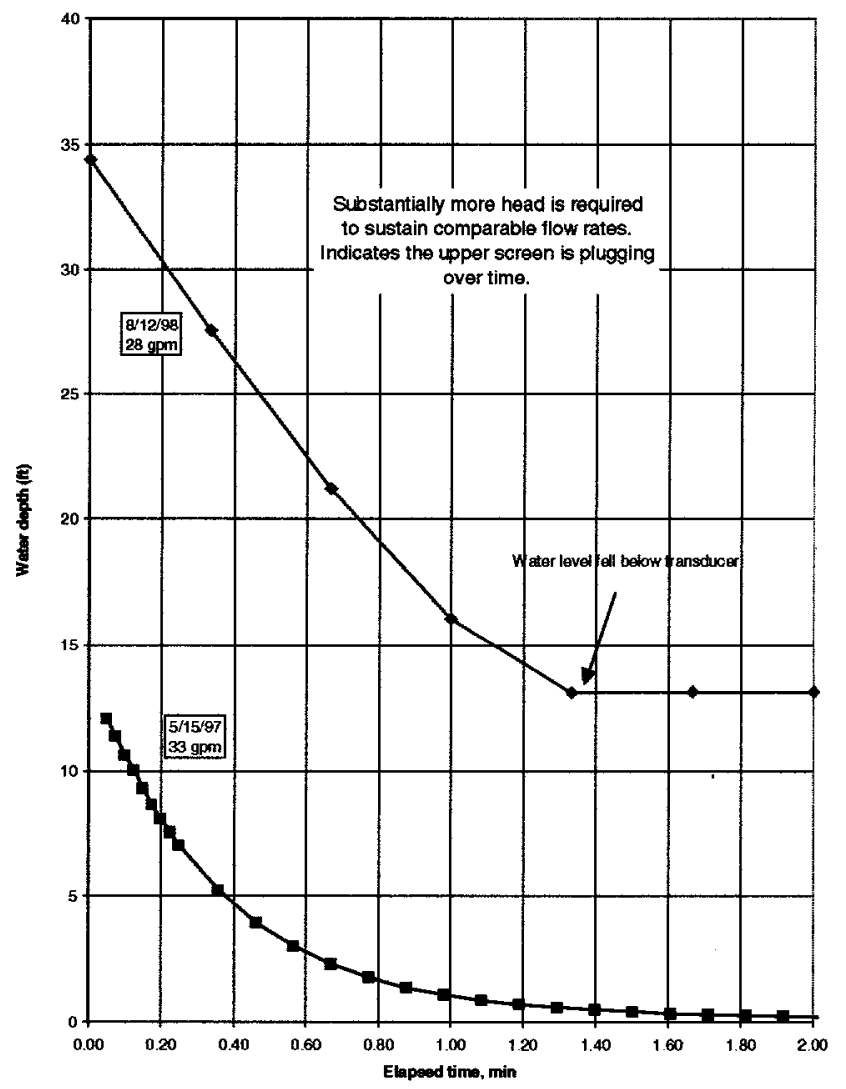

Figure 7: Water flow tests at SSR-012 
screen is plugging over time and as should be expected with any injection well, it eventually will need to be redeveloped. The rate of plugging does not appear to be a significant obstacle to long term operation.

After SSR-012 was redeveloped in April 1997, the 4 inch screen was raised 25 feet to allow additional head capacity above the upper screen zone to compensate for partial plugging over time. The 4 inch screen in all new wells will be located approximately 30 feet above the static potentiometric head.

\section{Initial Groundwater Quality}

Prior to placing the wells in service, a baseline of water quality in the piezometer clusters was established. Referring to Figure 25, the TCE concentration around well SSR-001 was about as expected; approximately $400 \mathrm{ppb}$ in the bottom of the aquifer and approximately $15-20 \mathrm{ppb}$ at the top of the aquifer. However at the observation wells around well SSR-012, TCE was found in excess of $10,000 \mathrm{ppb}$ in the bottom of the aquifer and approximately 3,000 ppb at the top of the aquifer (refer to Figure 27). The contaminant plume appears to extend much farther down gradient in the vicinity of SSR-012 than expected. Although this may lead to the redefinition of the overall plume treatment strategy at this site, it provided an excellent opportunity to evaluate recirculation well technology in a regime of higher contaminant concentrations.

Dissolved oxygen was found to be near saturation levels at the bottom of the aquifer (see Figure 37) but at relatively low levels at the top of the aquifer.

\section{Zone of Capture}

The Zone of Capture is that part of the aquifer from which groundwater is drawn into a well while it is pumping. In designing a treatment system to capture a contaminant plume, the wells must be spaced such that the Zones of Capture overlap to some degree. This helps to insure that the entire contaminant plume is captured. Initially, the proper well spacing was estimated from Herrling's model. Two methods were used to corroborate the original estimate.

First, drawdown measurements were made at the lateral wells to quantify the aquifer response to the operation of the recirculation well. Water level measurements taken at the lateral wells (SSM-005, 006, 007, and MSB-074) are shown in Figure 8. The drawdown levels taken while SSR-012 was in operation indicate that the hydraulic effect of the well extends at least to MSB074, approximately 160 feet lateral to the natural groundwater flow. From this data a simple particle tracking model was generated to predict the groundwater flow path and travel times from MSB-074 to SSR-012 (see Figure 9 and Table 2). The specific methodology is explained in detail in the initial report. Figure 8 illustrates that the hydraulic gradients created by the recirculation well are much stronger than the existing regional gradient. 


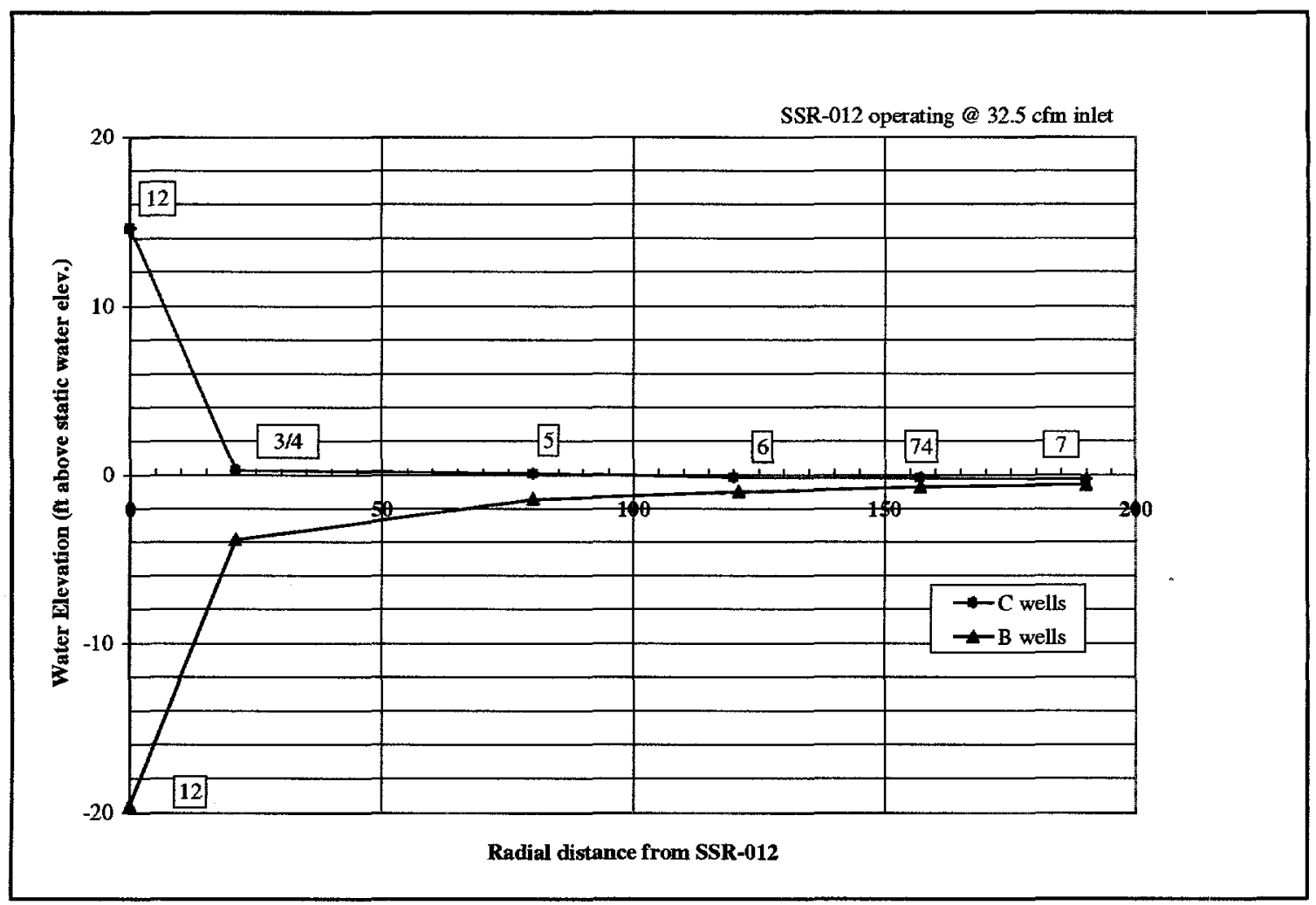

Figure 8: Potentiometric heads at lateral piezometers

As further corroboration, a tracer test was initiated on Feb. 6, 1998. Sodium bromide was introduced into MSB-074B at a concentration of $2,700 \mathrm{mg} / \mathrm{L}$ at a controlled rate of $1.1 \mathrm{~L} / \mathrm{min}$ over an 8 hour period. Samples were taken periodically at the observation wells between MSB-074 and SSR-012 and analyzed for bromide content. The results are shown in Figures $10-14$ in the Appendix. Figure 9 shows a very strong indication of bromide at well SSM-006B on the 41st day. Table 2 lists the travel times predicted by the model and the actual times of the tracer peaks for comparison.

Table 2: Tracer Results

\begin{tabular}{|c|c|c|c|c|c|}
\hline Well & $\begin{array}{c}\text { SSM- } \\
006 \mathrm{~B}\end{array}$ & $\begin{array}{c}\text { SSM- } \\
\text { 005B }\end{array}$ & $\begin{array}{c}\text { SSM- } \\
004 \mathrm{~B}\end{array}$ & $\begin{array}{c}\text { SSM- } \\
003 \mathrm{C}\end{array}$ & $\begin{array}{c}\text { SSM- } \\
004 \mathrm{C}\end{array}$ \\
\hline $\begin{array}{c}\text { Predicted } \\
\text { peak (days) }\end{array}$ & 40 & 80 & 110 & 111 & 111 \\
\hline $\begin{array}{c}\text { Actual peak } \\
\text { (days) }\end{array}$ & 41 & 68 & 134 & 143 & 157 \\
\hline
\end{tabular}

This is a positive indication that the bromide tracer followed the predicted path and was in fact under the hydraulic influence of the recirculation well. The bromide peaks downgradient are quite a bit weaker, indicating that the tracer had diffused or migrated slightly southward, nevertheless, the peaks occur at times reasonably close to what was predicted. This supports the conclusion that 
recirculation well SSR-012 has established a Zone of Capture of approximately 300 feet in diameter and our initial well spacing of 252 feet is reasonable.

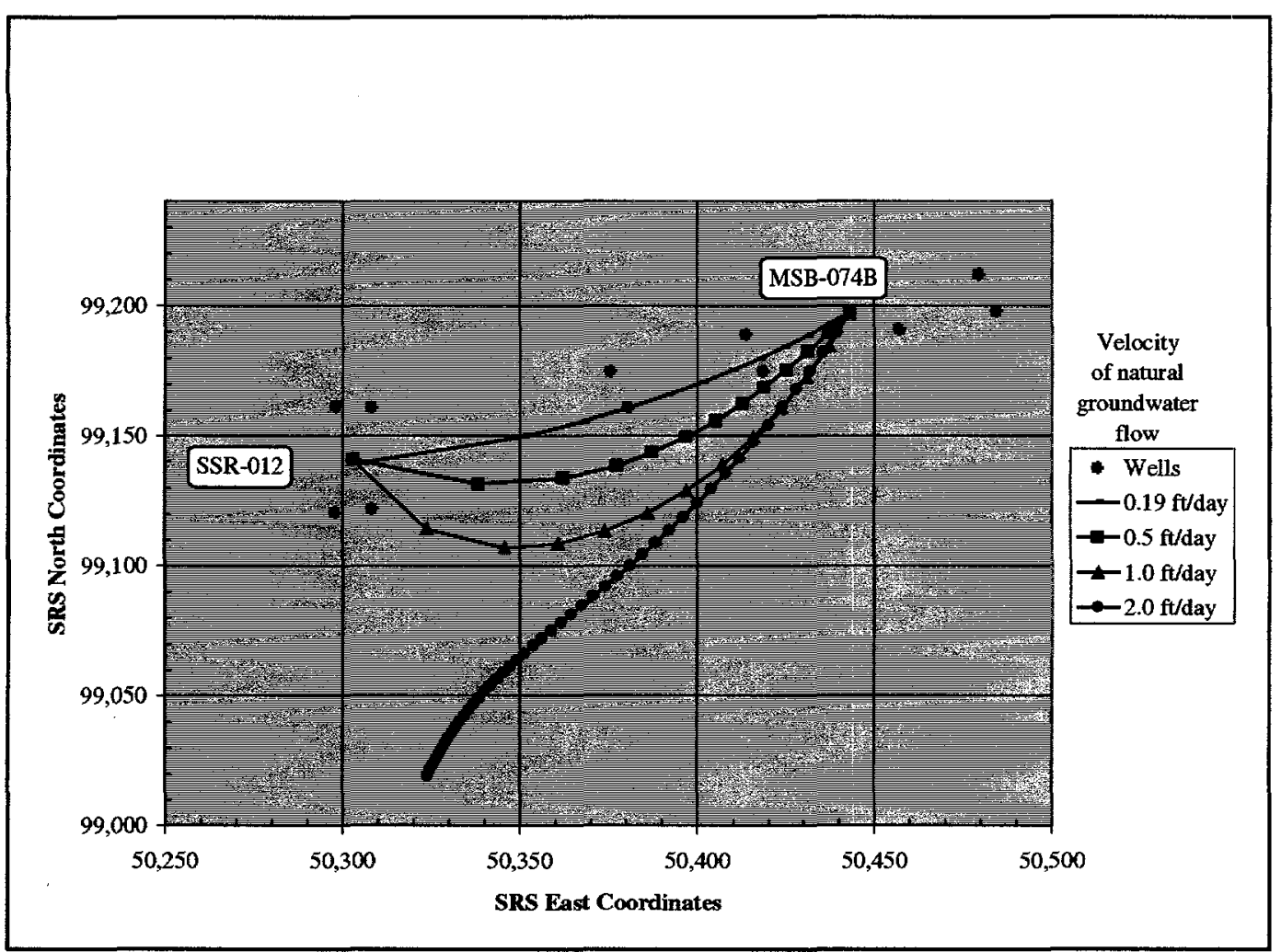

Figure 9: Simulated groundwater flow patterns

\section{Zone of Recirculation}

As water is drawn into the lower screen of the recirculation well and discharged back into the aquifer from the upper screen, a three-dimensional hydraulic gradient is created around the well. Because of the anisotropic ratio, $\mathrm{K}_{\mathrm{h}} / \mathrm{K}_{\mathrm{v}}$ (horizontal hydraulic conductivity / vertical hydraulic conductivity), the bulk of the discharge from the well flows radially outward, taking the path of least resistance. A smaller component of the flow is drawn downward and back into the well where it is again exposed to the stripping effect of the airlift pump. Herrling's model provides a theoretical mechanism to predict the relative size of the recirculated component of the well discharge, but a practical analysis of this ratio is beyond the scope of this report. The portion of the aquifer around the well in which this recirculating flow is significant is referred to as the Zone of Recirculation.

The physical dimensions of the Zone of Recirculation remain the subject of a certain amount of conjecture. The size of the ZOR is dependent upon the anisotropic ratio, the thickness of the aquifer, the length of the upper and lower screen zones, and the magnitude of the natural groundwater flow. Although Herrling's data provide a theoretical means to estimate the size and shape of the zone, we have no cost effective means of proving it. Herrling's model predicts that the 
ZOR will be nearly circular in cross-section, extending a distance of 137 feet up and downgradient and 132 feet on either side of the recirculation well, lateral to the natural flow of groundwater. Thus, with the 252 foot well spacing in the Southern Sector, the ZOR should extend completely from one well to the next.

In 1999, work is planned to model the flow patterns around SSR-012 on a finer scale. This is an opportunity to corroborate some of Herrling's results and is intended to provide additional insight into localized flow patterns and the ZOR.

\section{Test Configuration}

The recirculation well was equipped with variable orifice flowmeters (rotameters) on the inlet airline and in the exhaust stack. Thermometers and pressure gauges were installed in both air streams. In order to measure the water pumping rate, the well annulus (the area between the 8 inch well casing and the 4 inch airlift pump casing) was "calibrated" to establish a relationship between inlet airflow and water level. This was simply a stepwise tabulation of measured values. A similar relationship was then established between the water level in the annulus and the water flow out of the upper 8 inch screen. To do this a water level transducer was placed in the annulus below the static water level. The airflow was then turned on at a high flow rate (approximately $50 \mathrm{cfm}$ ). After conditions stabilized (approximately 10 minutes) the airflow was shut off and the decline in water level was recorded at very short time intervals using a data logger. The cross-sectional area of the annulus is constant, thus the decline in water level over incremental periods of time can be converted into a flow rate. The two relationships were plotted against their common parameter (water level) to create a nomograph that allows pumping rate to be approximated from inlet airflow. This nomograph is attached as Figure15. Typical operating parameters at SSR-012 are shown in Table 3.

Table 3: Typical Operating Parameters at SSR-012

\begin{tabular}{|c|c|c|c|c|c|}
\hline Date & Inlet Air Flow & $\begin{array}{c}\text { Est. Water } \\
\text { Pumping Rate }\end{array}$ & $\begin{array}{c}\text { Exhaust Air } \\
\text { Flow }\end{array}$ & $\begin{array}{c}\text { TCE Conc. in } \\
\text { Exhaust Air }\end{array}$ & $\begin{array}{c}\text { Stripping } \\
\text { Efficiency }\end{array}$ \\
\hline June, 1998 & $33 \mathrm{cfm}$ & $43 \mathrm{gpm}$ & $48 \mathrm{cfm}$ & $62.8 \mathrm{ppmv}$ & $63 \%$ \\
\hline
\end{tabular}




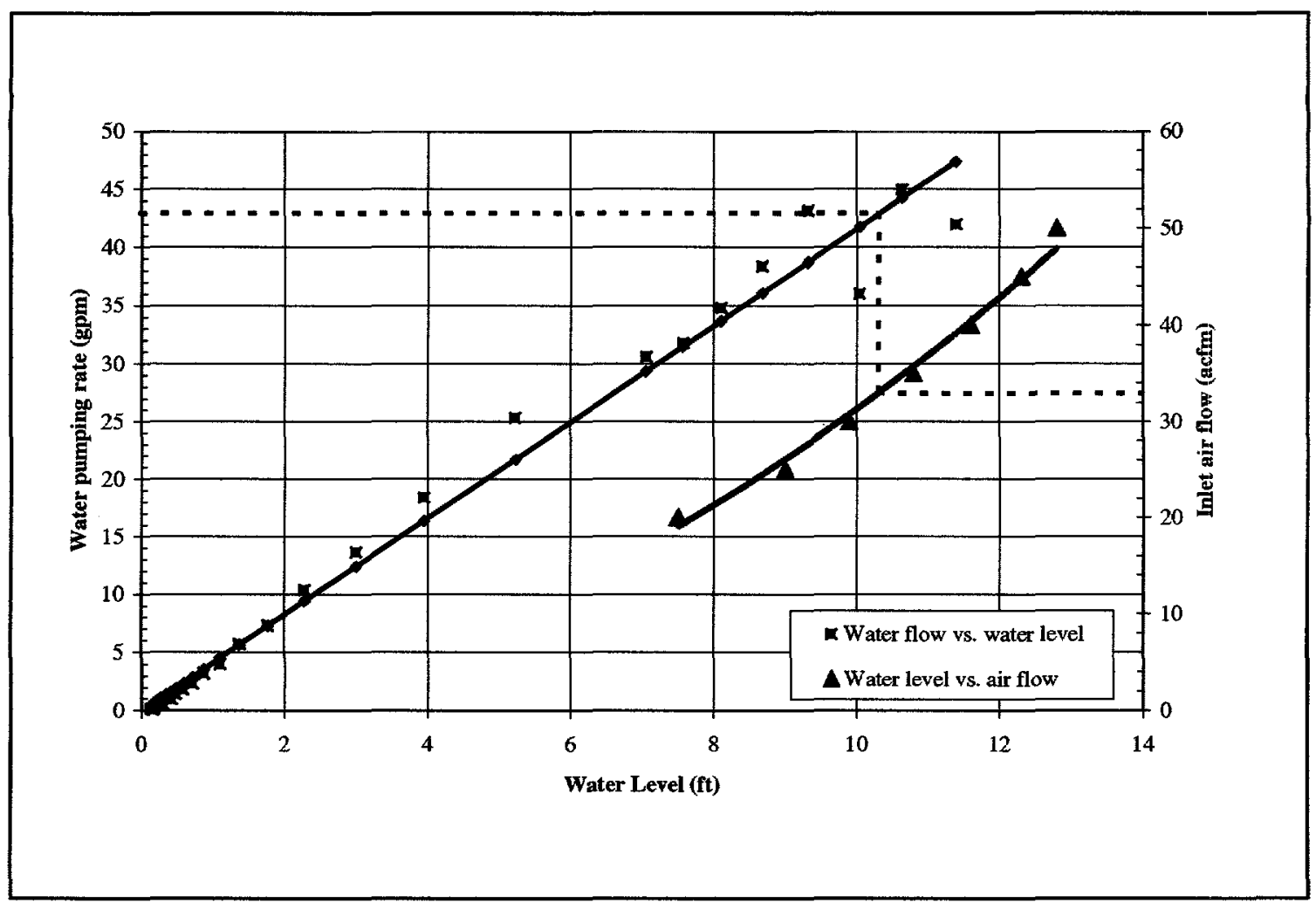

Figure 15: Pumping rate nomograph

\section{Stripping Efficiency}

Stripping efficiency is of interest because it provides a metric for comparing the effectiveness of the technology. Stripping efficiency is simply the percentage reduction in the contaminant level of the groundwater as measured at the inlet and outlet of the recirculation well. The stripping efficiency was evaluated by establishing a mass balance around the recirculation well. During the redevelopment of SSR-012 in April 1997, the lower screen zone was thoroughly pumped at 48 gpm. A number of water samples were taken which established a background TCE concentration of $4500 \mathrm{ppb}$ at the bottom of the aquifer. Note that this water is a mixture drawn from the entire Zone of Capture.

A simple mass balance for TCE yields:

$$
\text { Qao Cao + Qwo Cwo = Q Q } \quad \text { ai Cai + Qwi Cwi }
$$

where:

$$
\begin{array}{ll}
\text { Qao } & =\text { air flow rate from exhaust stack } \\
\text { Qai } & =\quad \text { air flow rate into the well }
\end{array}
$$


Qwo $=$ groundwater flow out of the upper screen
Qwi $=\quad$ groundwater flow into the lower screen
Cao $=\quad$ concentration of TCE in exhaust air
Cai $=\quad$ concentration of TCE in air supply
Cwo $=\quad \begin{aligned} & \text { concentration of TCE in the groundwater discharging into the upper screen } \\ & \text { zone }\end{aligned}$

Cwi $=$ concentration of TCE in the groundwater at the inlet to the airlift pump.

If we neglect evaporation,

Qwi $\cong \quad$ Qwo

Periodic testing of the inlet air has confirmed that,

Caì $\cong \quad 0$

Substituting and rearranging,

Qwo Cwo = Qwo Cwi - Qao Cao

Substituting values from Table 3 and converting to common units yields:

$$
\begin{aligned}
\text { Qwo Cwi }= & 43 \mathrm{gal} / \mathrm{min} \times 4,500 \mathrm{lb} . \mathrm{TCE} / 10^{9} \mathrm{lb} . \mathrm{H}_{2} \mathrm{O} \times 8.34 \mathrm{lb} . / \mathrm{gal} \\
= & 0.0016 \mathrm{lb} . \mathrm{TCE} / \mathrm{min} . \\
\text { Qao Cao }= & 48 \mathrm{ft}^{3} \mathrm{air} / \mathrm{min} \times 62.8 \mathrm{ft}^{3} \mathrm{TCE} / 10^{6} \mathrm{ft}^{3} \mathrm{air} \mathrm{X} \\
& 131.5 \mathrm{~g} \mathrm{TCE} / 24.5 \mathrm{LCE} \times 28.3 \mathrm{~L} / \mathrm{ft}^{3} \times 1 \mathrm{lb} . / 454 \mathrm{~g} \\
= & 0.0010 \mathrm{lb} . \mathrm{TCE} / \mathrm{min} . \\
\text { Qwo Cwo }= & (0.0016-0.0010) \mathrm{lb} . \mathrm{TCE} / \mathrm{min} . \\
= & 0.0006 \mathrm{lb} . \mathrm{TCE} / \mathrm{min} . \\
= & 0.0006 \mathrm{lb} . \mathrm{X} 10^{9} / \mathrm{min} /(43 \mathrm{gal} / \mathrm{min} \times 8.34 \mathrm{lb} . / \mathrm{gal}) \\
\text { Cwo } & 1673 \mathrm{ppb} .
\end{aligned}
$$


Defining single pass stripping efficiency $(\eta s)$ as:

$$
\begin{aligned}
\eta \mathrm{s} & =(\mathrm{Cwi}-\mathrm{Cwo}) / \mathrm{Cwi} \\
& =(4,500-1,673) / 4,500 \\
& =62.8 \% .
\end{aligned}
$$

Historically, the single pass stripping efficiency at SSR-012 has been in the $40-70 \%$ range with the original configuration. While this does not account for supplemental mass removal resulting from the recirculation of the treated water, the first pass stripping efficiency is a significant quantifiable measure of the performance of the ARW. In an attempt to improve the stripping efficiency, new technologies were solicited that could be adapted to the original configuration.

\section{Multi-Stage In-Well Aerator}

In September, 1998 the airlift pump was removed from SSR-012 and replaced with a MultiStage In-Well Aerator (MIA) designed by Davis Environmental.

This technology also utilizes airlift pumping, but as shown in Figure 14, incorporates additional spargers in the upper and lower screen zones. Thus it utilizes three stages of stripping. The technology has been successfully applied at the University of California - Davis. Initial testing of this configuration at SSR-012 has produced single pass stripping rates of $80-90 \%$. Although the results are very promising, additional testing is needed to confirm these results.

\section{Overall Treatment Efficiency}

As can be seen from the attached Tables and Charts, recirculation well SSR-012 has performed very well. Figure 17 illustrates the contaminant mass removed from the aquifer by the recirculation well. Figure 18 illustrates the decline in contamination levels at the lateral wells during the course of the demonstration. Referring back to Figure 1, some of this reduction may be due to the hydraulic control of the plume itself. As the plume is pulled towards the recirculation well, cleaner water from the east is drawn in and displaces the more heavily contaminated water. This again is evidence that the recirculation well technology has established hydraulic control over the edge of the plume. 


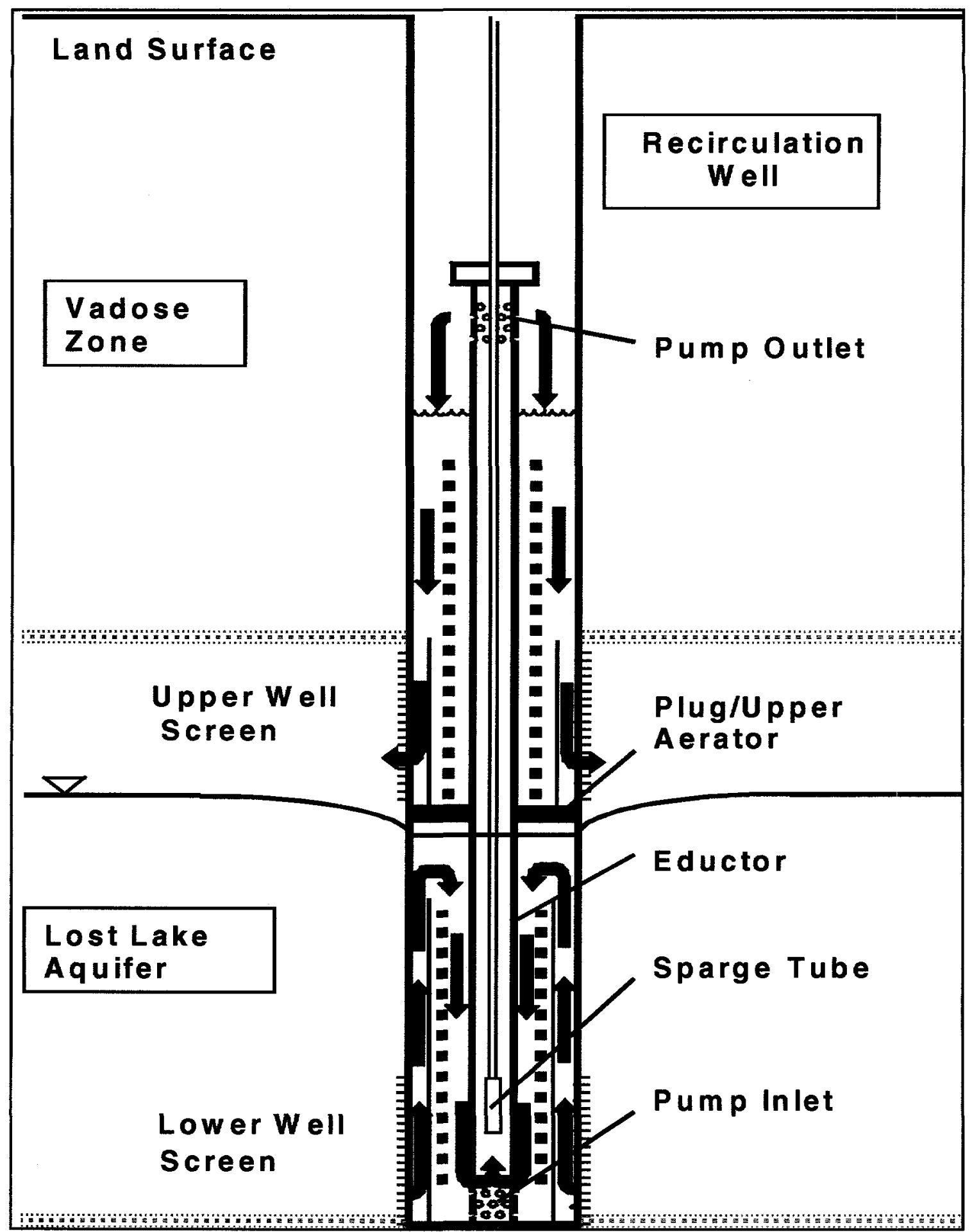

Figure 16: Multi-stage In-well Aerator 


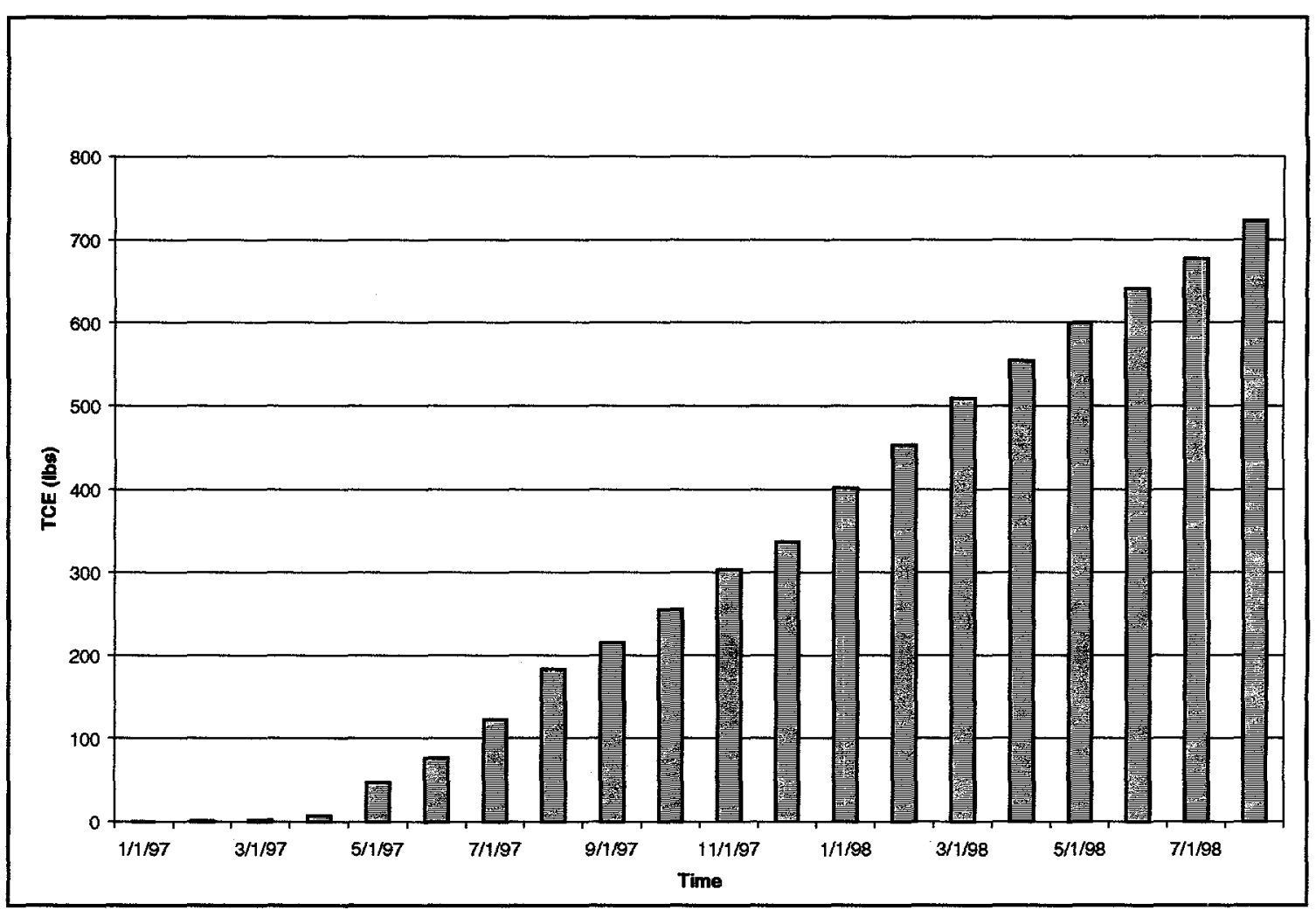

Figure 17: TCE mass removed at SSR-012

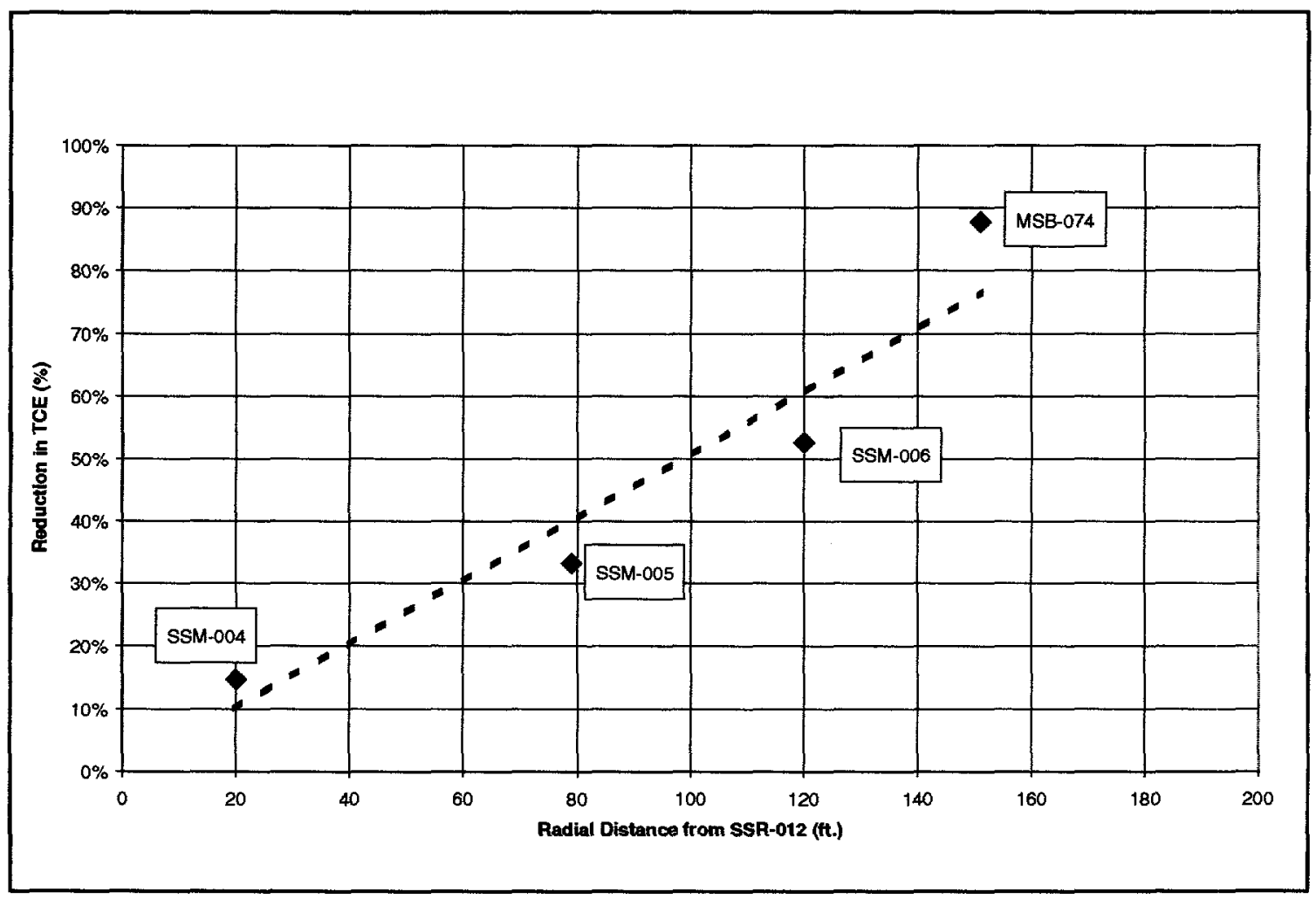

Figure 18:TCE reduction at nearby wells 
Much of the effectiveness of the ARW technology hinges upon two factors; the first pass stripping efficiency and the number of passes that a typical water particle makes through the well as it passes through the Zone of Capture. We can determine the first factor relatively easily, as demonstrated earlier. The second factor is much more elusive and lends itself to diverse academic discussion. A simplistic evaluation is presented below.

If we assume that the recirculation cell functions as a continuous flow stirred-tank reactor (CFSTR), a very simple model can be created to predict downgradient contaminant concentrations over time. Although the underlying assumptions; complete mixing within the cell, uniform flows, etc., might be expected to contrast sharply with real conditions, the model does provide a simple comparative metric for the purpose of conceptual discussion. The model schematic is presented in Figure 19.

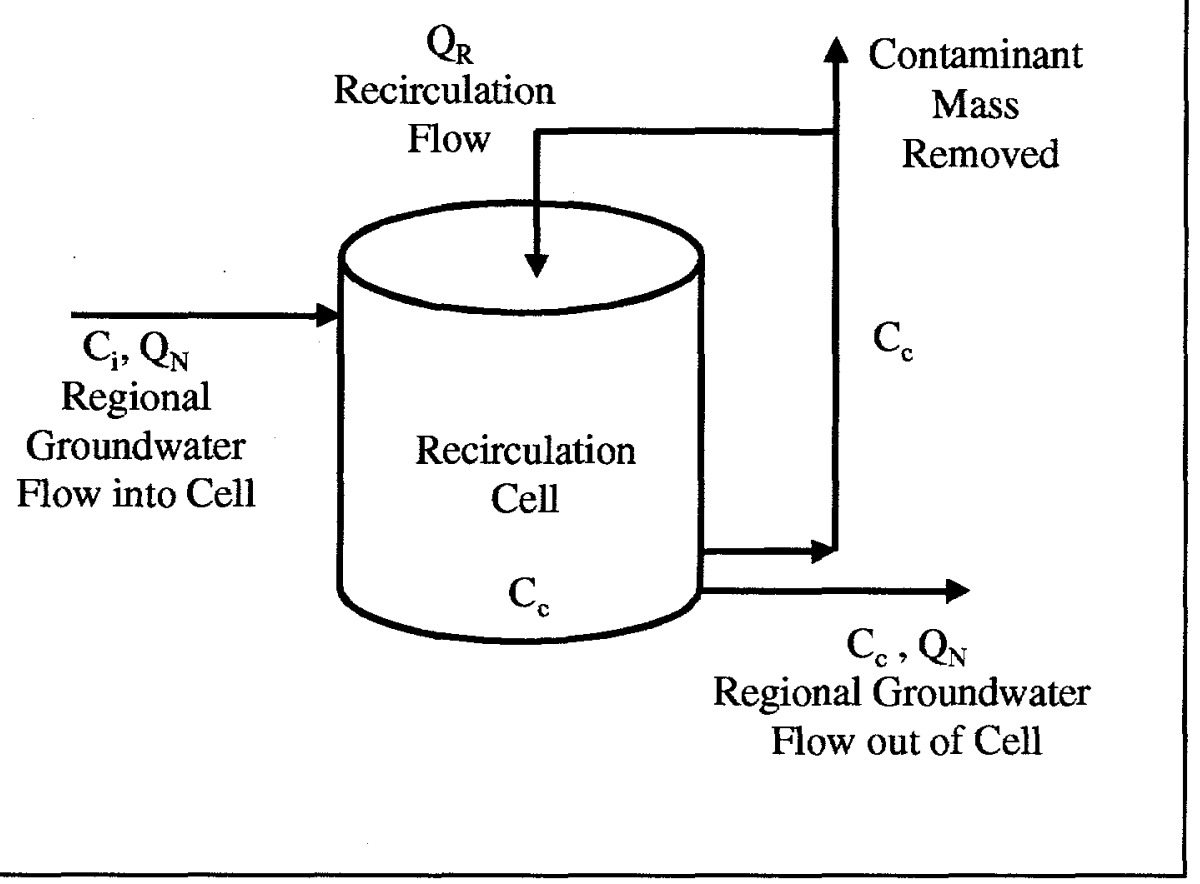

\section{Figure 19: CFSTR model schematic}

TCE mass flow into the recirculation cell $=$ TCE mass flow out of the recirculation cell

TCE mass flow into the recirculation cell $=Q_{N} C i+Q_{R} C_{C}(1-\eta s)$

where,

$\mathrm{QN}_{\mathrm{N}}=$ the regional groundwater flow into the cell,

$\mathrm{C}_{\mathrm{I}}=$ the TCE concentration in the groundwater upgradient of the well

$\mathrm{Q}_{\mathrm{R}}=$ the recirculation well water pumping rate, 
$\mathrm{C}_{\mathrm{C}}=$ the contaminant concentration within the recirculation cell, and

$\eta s=$ the first pass stripping efficiency.

QN can be approximated by,

$\mathrm{Q}_{\mathrm{N}}=\mathrm{v} \mathrm{B} \mathrm{D} \mathrm{p}$

where

$\mathrm{v}=$ the regional groundwater velocity

B $=$ the aquifer thickness

$\mathrm{D}=$ the width of the recirculation cell, and

$\mathrm{p}=$ the porosity of the aquifer.

Substituting values,

$$
\begin{aligned}
Q_{N} & =(0.19 \mathrm{ft} / \text { day })(54 \mathrm{ft})(252 \mathrm{ft})(0.2)(7.48 \mathrm{gal} / \mathrm{cu} . \mathrm{ft} .)(1 \mathrm{day} / 1440 \mathrm{~min}) \\
& =2.7 \mathrm{gpm} .
\end{aligned}
$$

TCE mass flow out of the recirculation cell $=Q_{N} C c+Q_{R} C_{C}$.

The initial conditions were assumed to be:

$$
\begin{aligned}
& \mathrm{C}_{\mathrm{i}}=10,000 \mathrm{ppb} \mathrm{TCE} \\
& \mathrm{Q}_{\mathrm{R}}=43 \mathrm{gpm} \\
& \mathrm{C}_{\mathrm{C}}=4,500 \mathrm{ppb} \mathrm{TCE} .
\end{aligned}
$$

A spreadsheet model was used to calculate the concentration of TCE in the discharge from the recirculation well over a one year period at stripping efficiencies of $50 \%, 65 \%$, and $100 \%$. As can be seen in Figure 20, the TCE level was reduced to less than 1,500 ppb within one year and the concentration was continuing to decline although at a declining rate. Given the simplifying assumptions used in this exercise, we would expect the actual results to differ somewhat, but the general trend should be similar. More sophisticated modeling techniques are planned for the future to allow more realistic forecasts. 


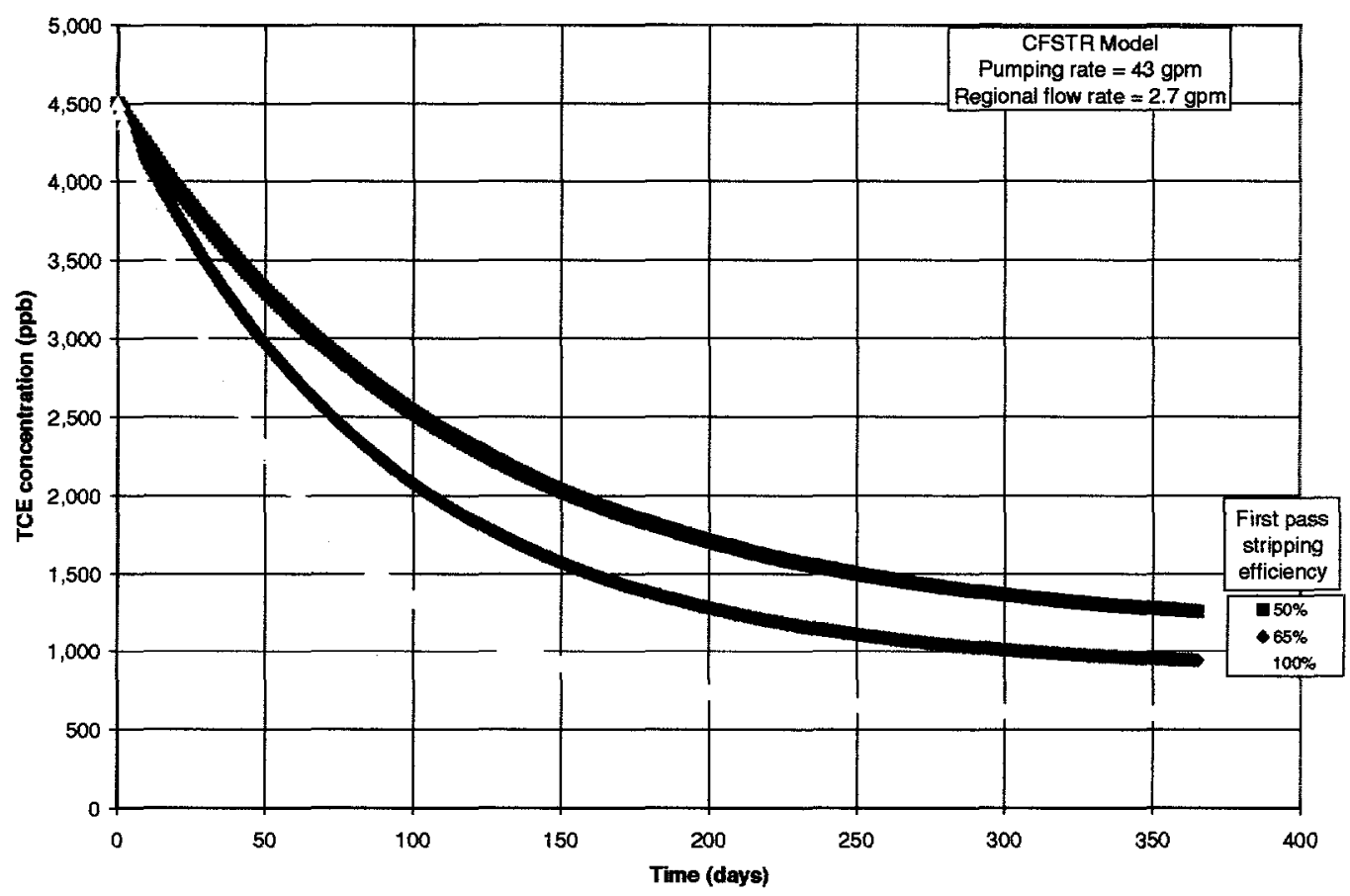

Figure 20: Results of CFSTR model

\section{Time to Establish a Recirculation Cell}

Early in the testing, pressure transducers were installed in MSB-074 B \& C to measure the aquifer response as SSR-012 was started up. The results are shown in Figure 21. One of the objectives of this project was to determine the time to establish a recirculation cell and how quickly the cell would degrade after the recirculation well was shut down. This information was to provide an idea of how long components could be out of service due to breakdown or for routine maintenance without adversely effecting the treatment objectives of the system. Figure 21 shows that the gradient controlling the recirculating flow of water is established within minutes of placing the well in service. The time required for a water particle to travel from the outer edge of the Zone of Capture to the recirculation well is approximately 140 days as demonstrated in the tracer experiment. The gradient at the top of the aquifer is not as large as the gradient at the bottom of the aquifer so the flow outward will not be as fast.

This is evident from the dissolved oxygen data presented in Figures 34-43. The low naturally occurring D.O. levels at the top of the aquifer create an environment where the dissolved oxygen serves as an effective tracer. Note that after SSR-012 was placed in service, the D.O. levels in the surrounding " $\mathrm{C}$ " wells began to rise. We might consider the point at which the D.O. level in each " $C$ " well reached the same level as that of the corresponding " $B$ " well as an indication that the recirculation cell had reached equilibrium. By this measure, the recirculation cell grew to a radius of 120 feet (at SSM-006) over a period of 265 days (Figure 39). Judging by the tracer test results 
and the D.O. results a complete round trip for a water particle may take between 300 and 500 days.

At startup of the recirculation well the actual recirculation cell gradients are formed within minutes (Figure 21). The recirculation cell then becomes a dynamic mixing zone and may require years to establish steady state conditions. The cell will likewise degrade very quickly if the wells are removed from service; within hours. The aquifer will then return to its natural gradient. The groundwater at the southernmost boundary of the recirculation cell will flow out of the Zone of Capture at the natural flow velocity of 0.19 feet/day. The contaminant concentration of this water will be much lower than the untreated upgradient water, conceivably at less than $100 \mathrm{ppb}$. Given the low regional flow gradient, short periods of downtime (a few days at the most) for equipment maintenance should not result in gross lapses in groundwater remediation.

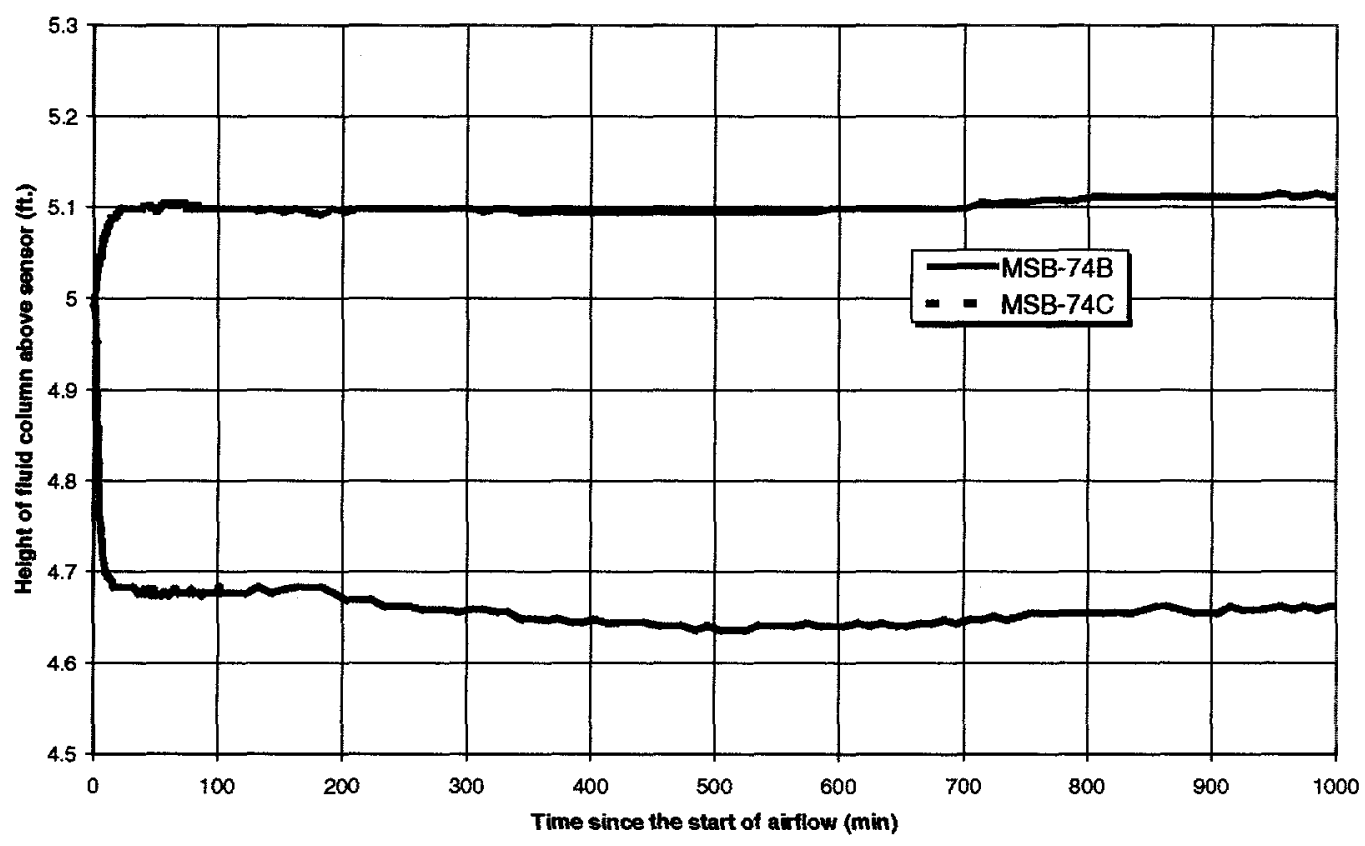

Figure 21: Aquifer response at MSB-074

\section{Conclusions}

The test results obtained over the past two years have confirmed the viability of the vertical recirculation well technology in this particular application. The success of the technology has been dependent upon the particular hydrostratigraphy of the Lost Lake aquifer. The relatively coarse sandy aquifer, with little clay/silt stratification, bounded on the top and bottom by clay rich 
confining layers with an anisotropic ratio of 18 seem to be key parameters for success. The results are consistent with model developed by Herrling, et. al.

Figure 17 illustrates the cumulative contaminant mass that has been removed from the aquifer since it was placed in service. The system has proved to be very reliable and has consistently removed over $1 \mathrm{lb}$. of TCE per day.

Figures 22 and 23 illustrate the shifts evident in the 8,000 ppb TCE isocontour in the vicinity of SSR-012. Each isocontour was created from the sampling data from the surrounding wells in the month indicated. The $8,000 \mathrm{ppb}$ isocontour was presented because data in the 6,000 to $8,000 \mathrm{ppb}$ range appears regularly and is easily tracked. Other isocontours could have been shown, but this one seemed representative of the general trends. These curves are crude approximations based upon sampling data and although the exact shape of each curve is subject to individual interpretation, as a whole they provide strong evidence that while SSR-012 was in service, the TCE plume was being successfully remediated.

Figure 22: 8,000 ppb TCE isocontours near SSR-012 with the well in service

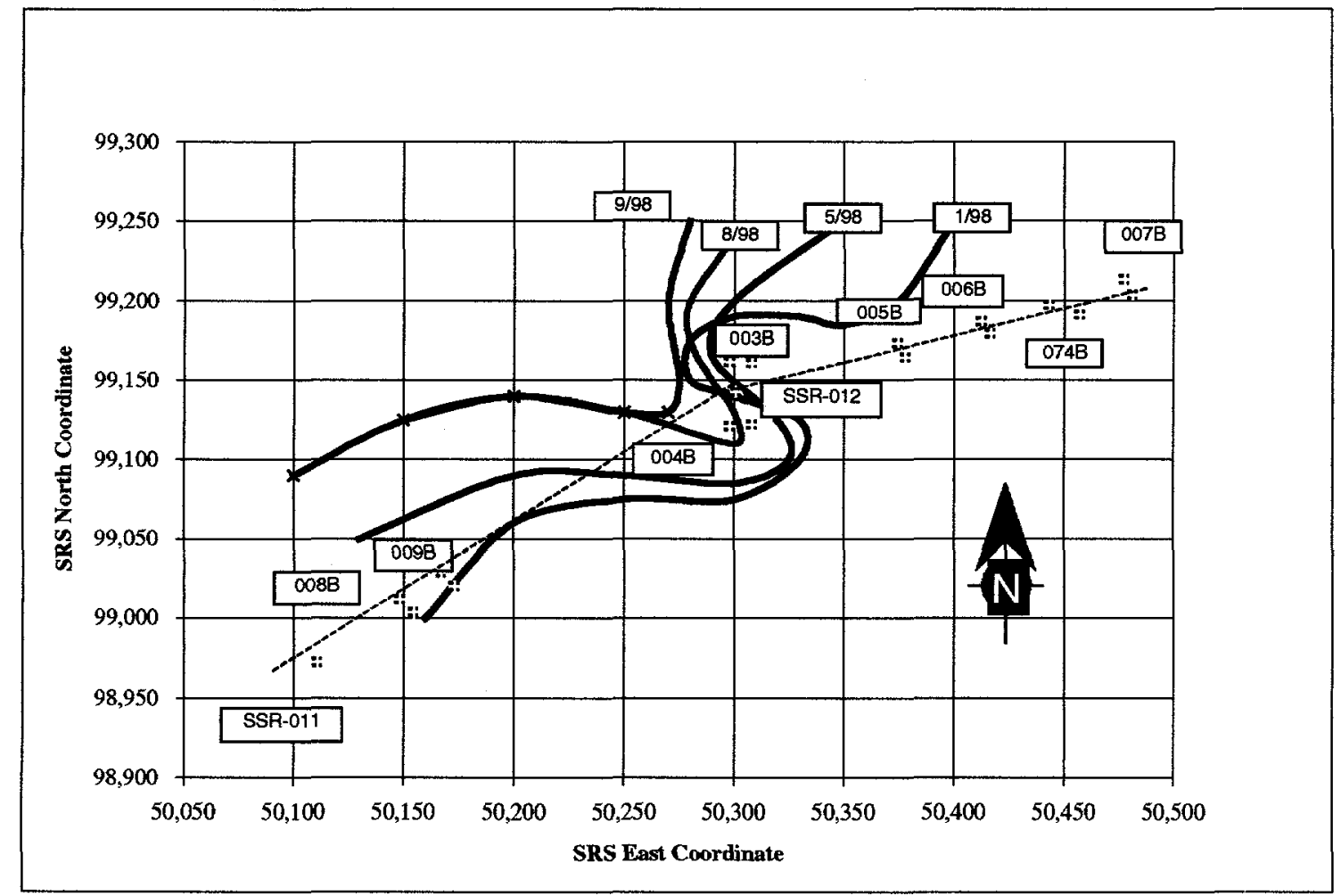


Figure 22 illustrates the effect of the recirculation well on the TCE concentration in the aquifer while the well was operating. Note that as contaminant mass is being removed from the groundwater (as demonstrated in Figure 17), the regional TCE concentration is falling. As discussed earlier, the recirculation well was removed from service in September 1998, to allow the installation and testing of the Multi-Stage In-Well Aerator. After the initial tests with the MIA configuration, the well remained out of service while utility and component upgrades were completed in the area. Figure 23 illustrates the return of higher contamination levels while the well was out of service, corroborating the benefits of the ARW technology.

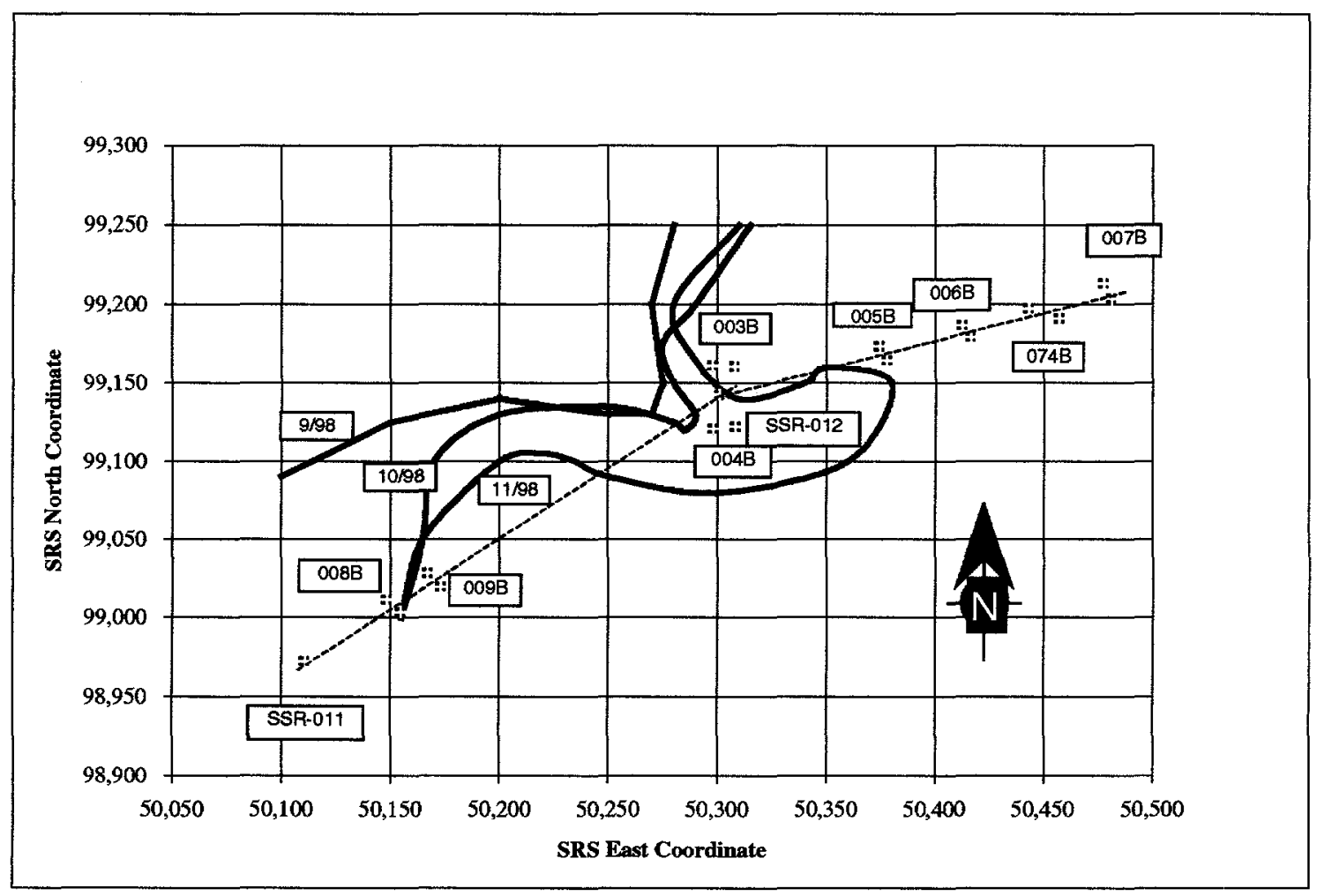

Figure 23: 8,000 ppb TCE isocontours near SSR-012 after the well was shut down

As with many endeavors, as we have gathered information and operating experience with the technology, new questions have arisen. Because of the significant promise of improved efficiencies offered by the MIA technology, it is recommended that further testing be completed to corroborate the initial results. Additionally, the location of piezometers between SSR-011 and SSR-012 offers an excellent opportunity to study the overlap of the Zones of Capture and Recirculation. The resulting knowledge will prove valuable as we pursue additional applications for the ARW technology. 


\section{References}

Looney, Brian B. and Phifer, Mark A., 1994, A/M Area Groundwater Corrective Action Southern Sector Remediation Technology Alternatives Evaluation, WSRC-RP-94-607.

Herrling, B., and Stamm, J., 1991, Numerical results of calculated 3D vertical circulation flows around wells with two screen sections for in situ on on-site remediation, Proc. IX International Conference on Computational Methods in Water Resources, Denver, CO.

Alesi, E.J., Brinnel, P., Herrling, B., Hirschberger, F., Sick, M.R. and Stamm, J., 1991, In Situ groundwater remediation of strippable contaminants by vacuum vaporizer wells (UVB): operation of the well and report about cleaned industrial sites, Third Forum on Innovative Hazardous Waste Treatment Technologies: Domestic and International, Dallas, TX.

Jackson, Dennis G. and Looney, Brian B., 1996, Development of a Vertical Recirculation Well System for the A/M Area of the Savannah River, WSRC-RP-96-477.

Hiergesell, R.A. and Nichols, R.L., 1997, Estimation of vertical hydraulic conductivity of the Lost Lake Aquifer near recirculation well SSR-012, SRT-EST-97-433.

Hiergesell, R.A. and White, R.M., 1997, Airlift Recirculation Well Test Results - Southern Sector, WSRC-TR-97-00246SRT-EST-97-433.

Stagner, Joe, 1998, Multi-Stage In-Well Aerator Performance Test Results - Well SSR-012. 


\section{Appendix}




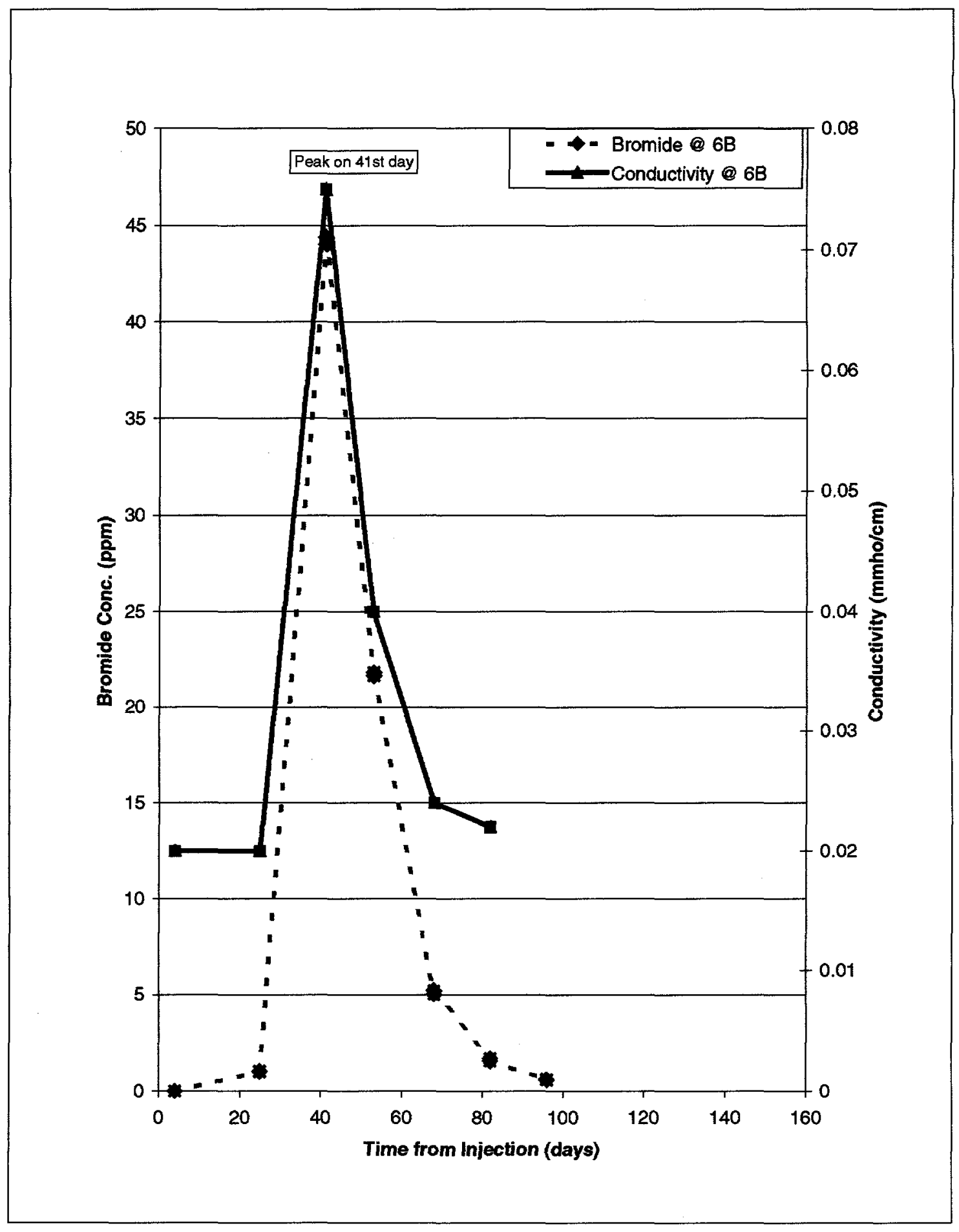

Figure 10: Bromide tracer concentration at SSM-006B 


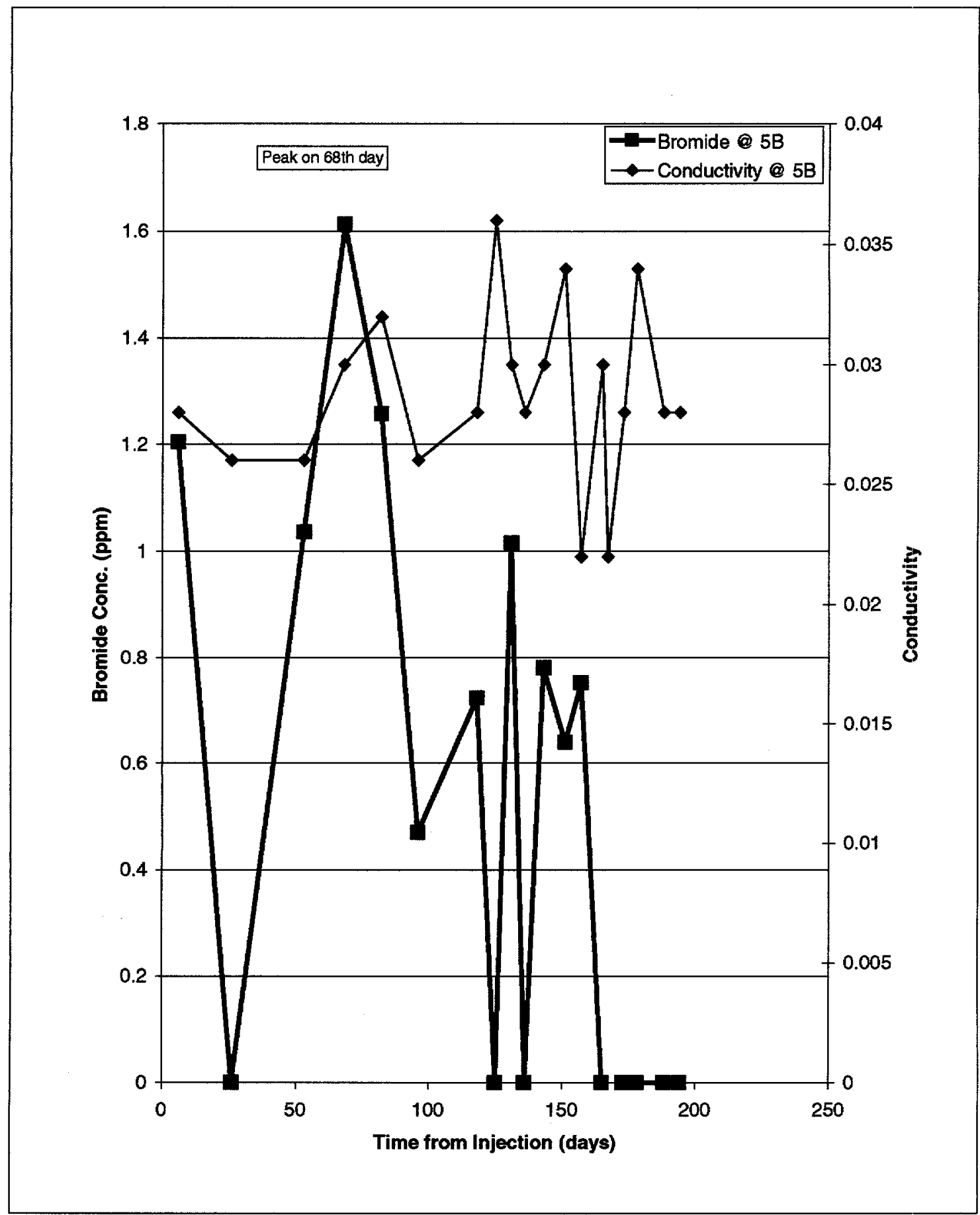

Figure 11: Bromide tracer concentration at SSM-005B 


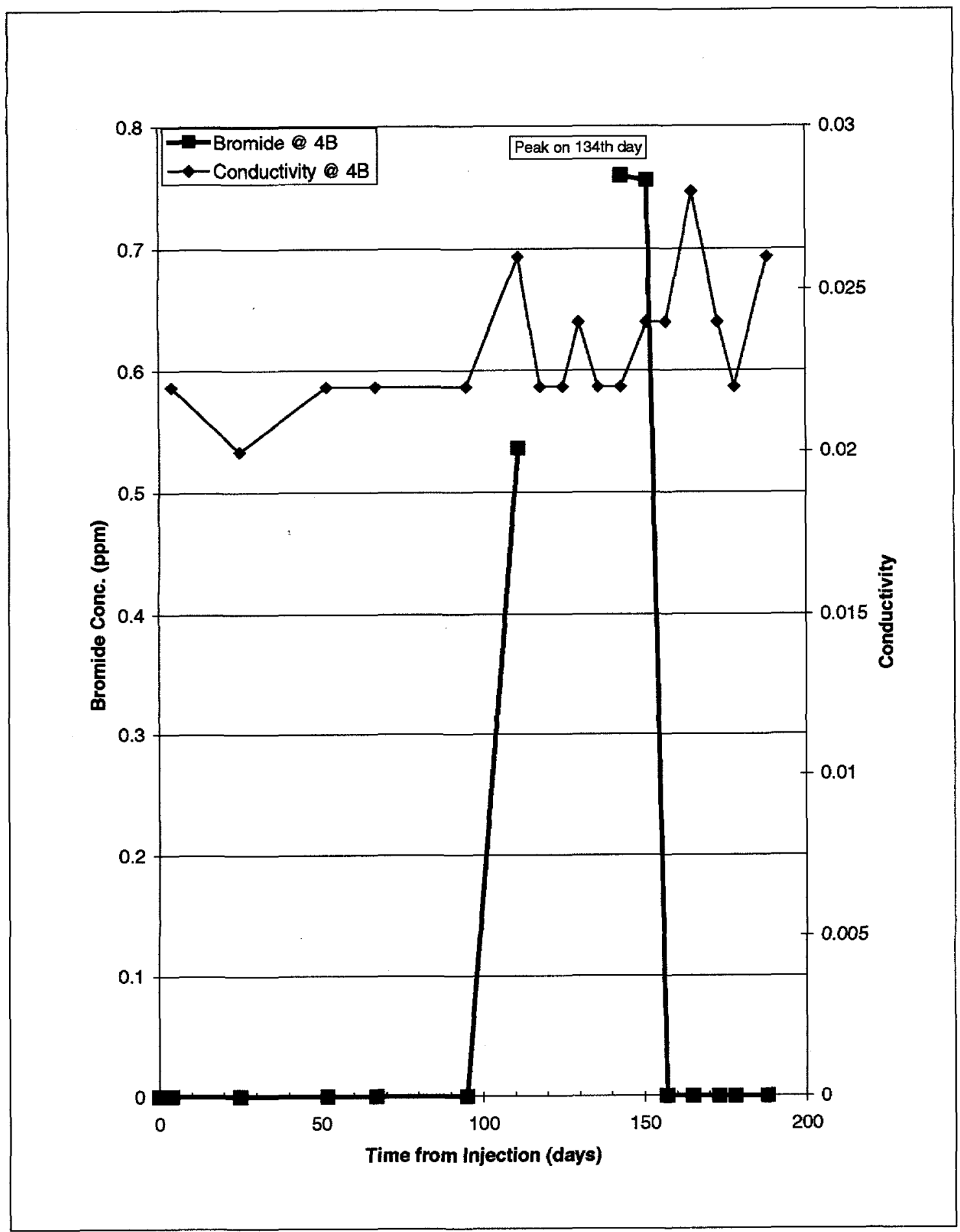

Figure 12: Bromide tracer concentration at SSM-004B 


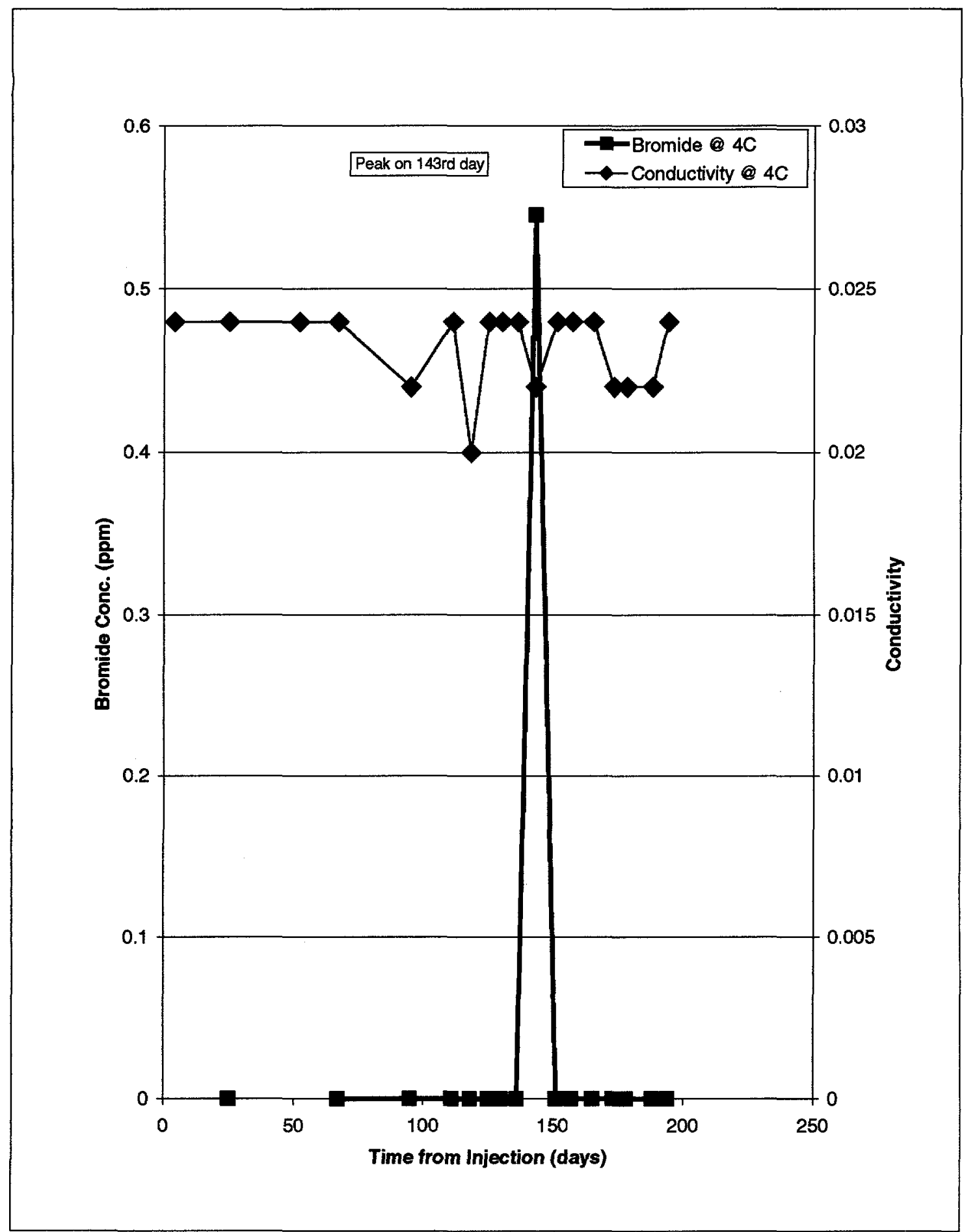

Figure 13: Bromide tracer concentration at SSM-004C 


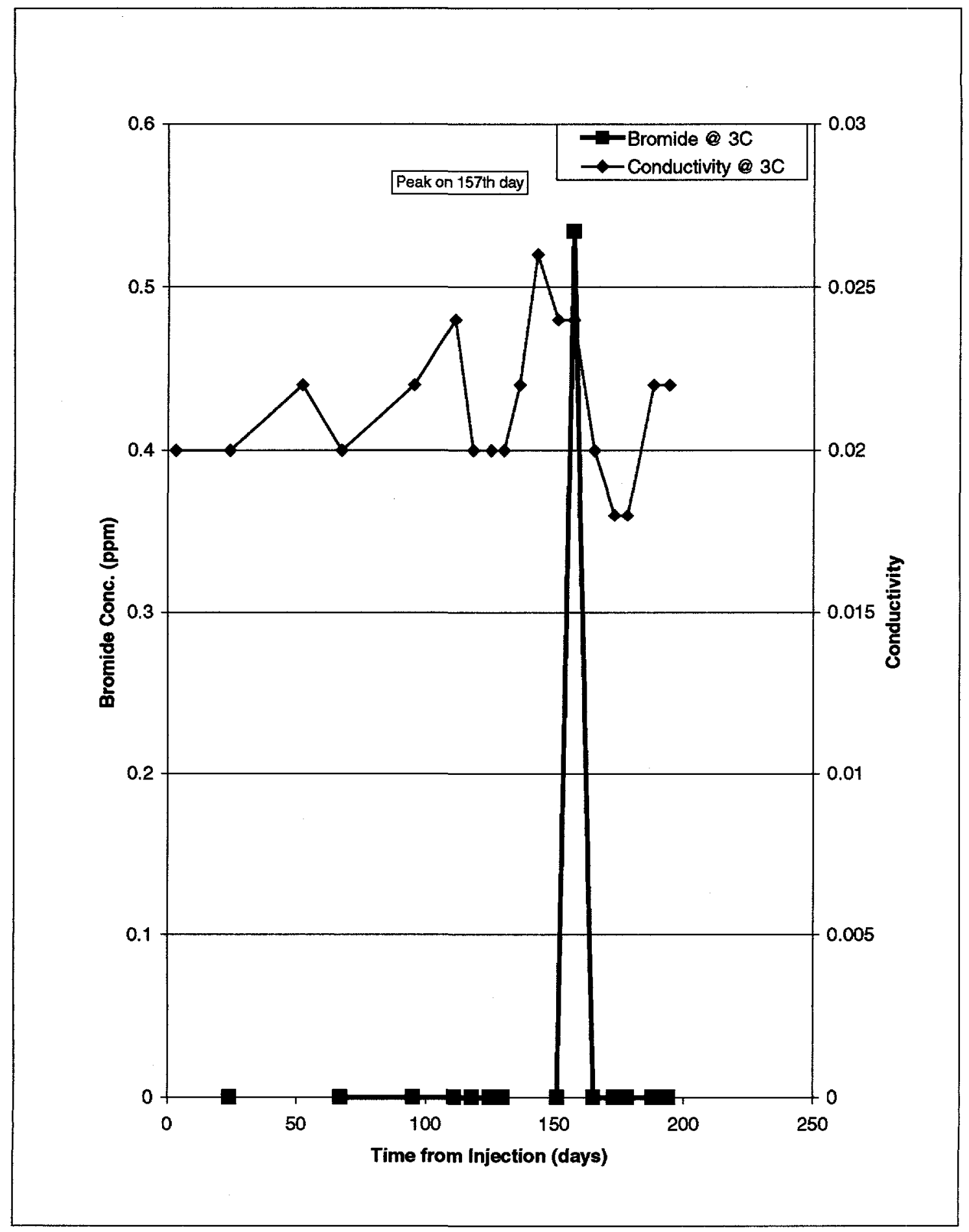

Figure 14: Bromide tracer concentration at SSM-003C 


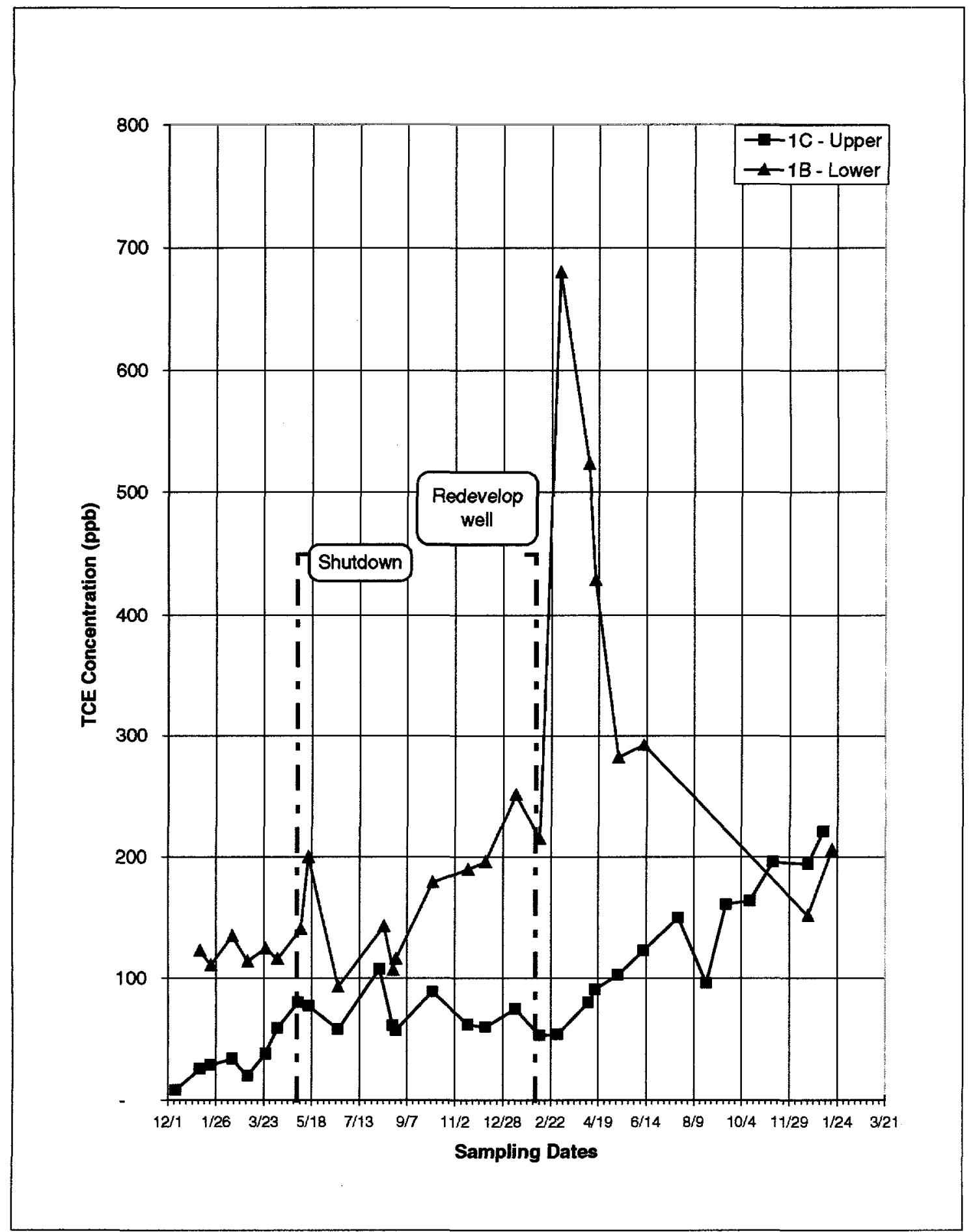

Figure 24: Groundwater sample analytical results - SSM-001 


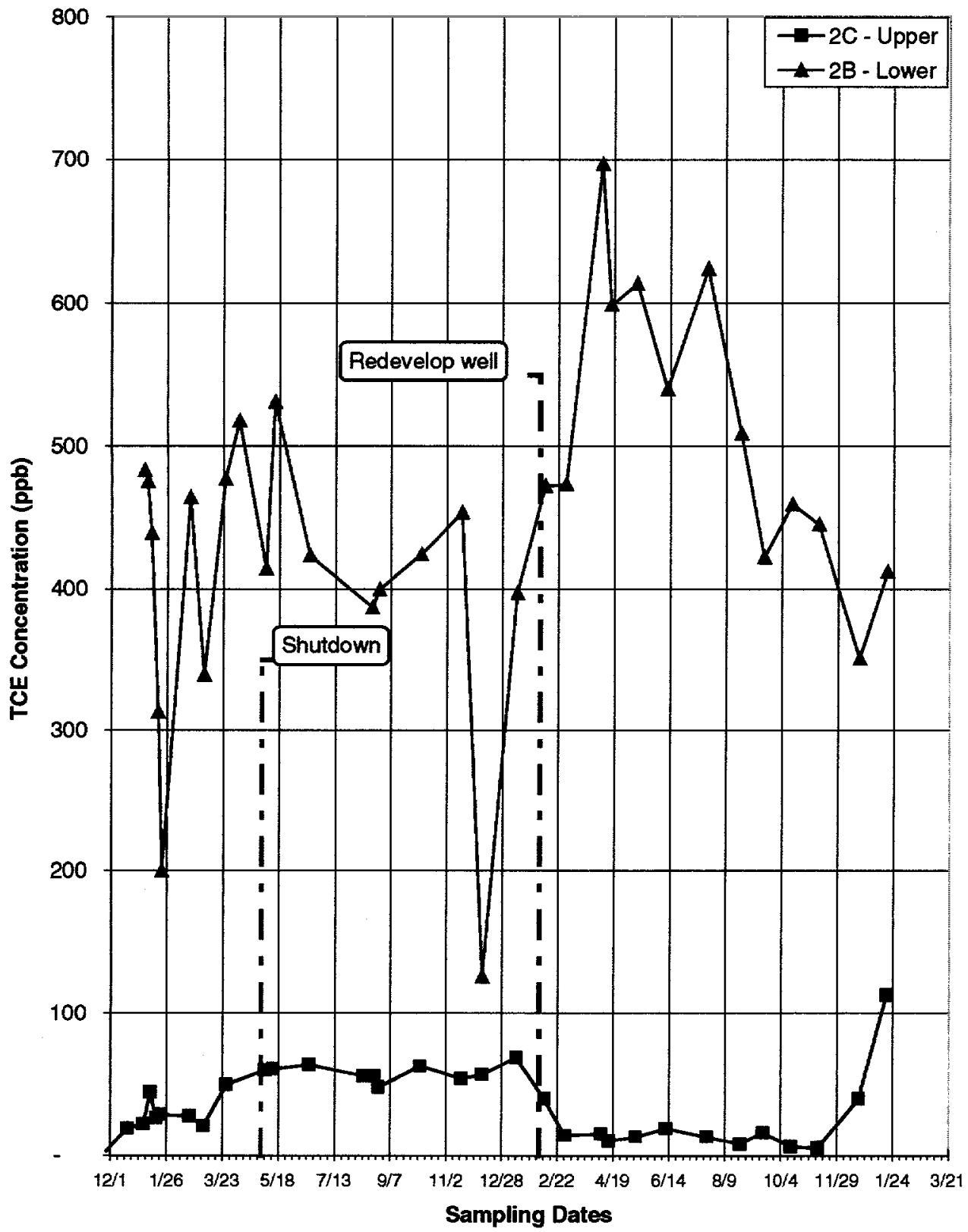

Figure 25: Groundwater sample analytical results - SSM-002 


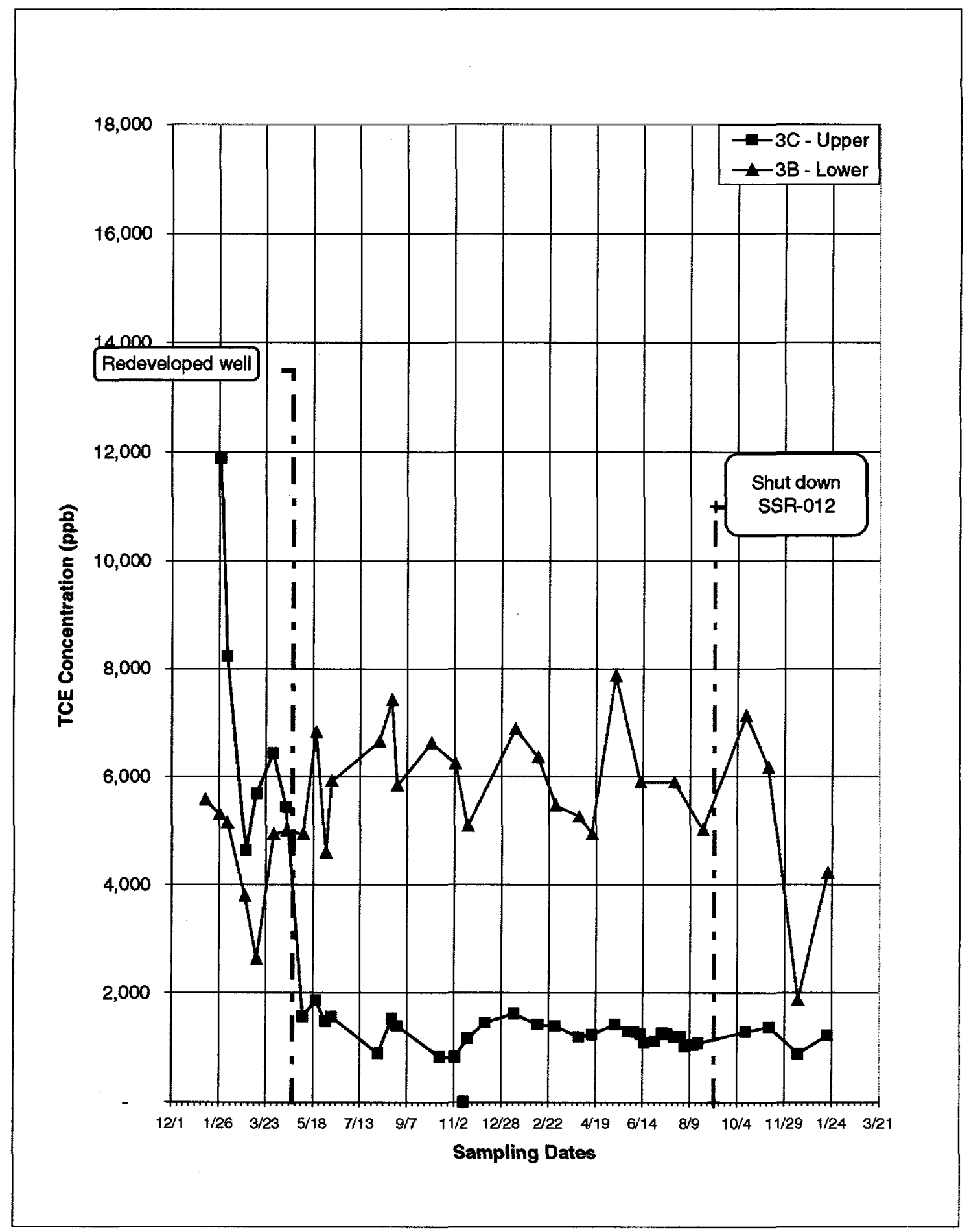

Figure 26: Groundwater sample analytical results - SSM-003 


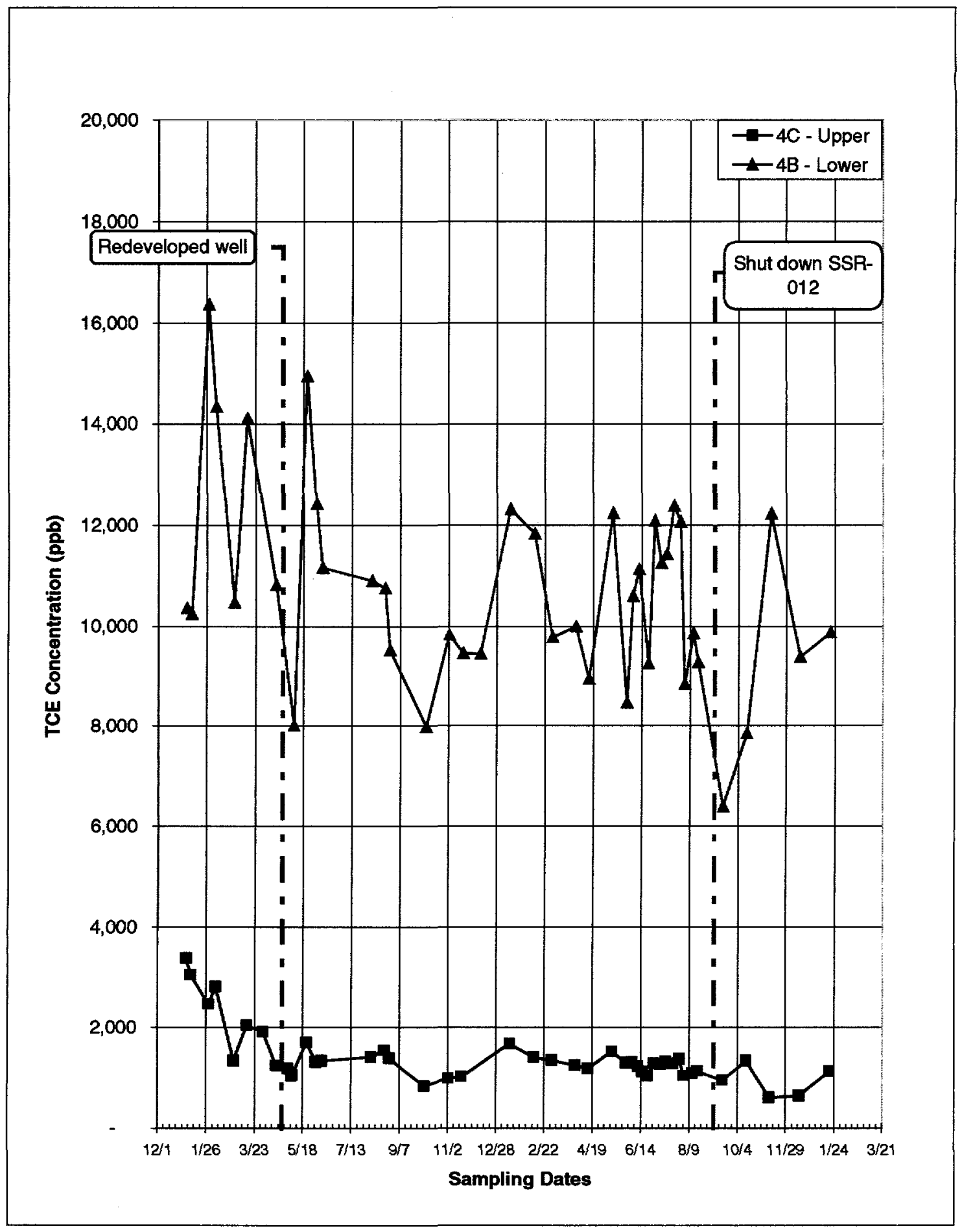

Figure 27: Groundwater sample analytical results - SSM-004 


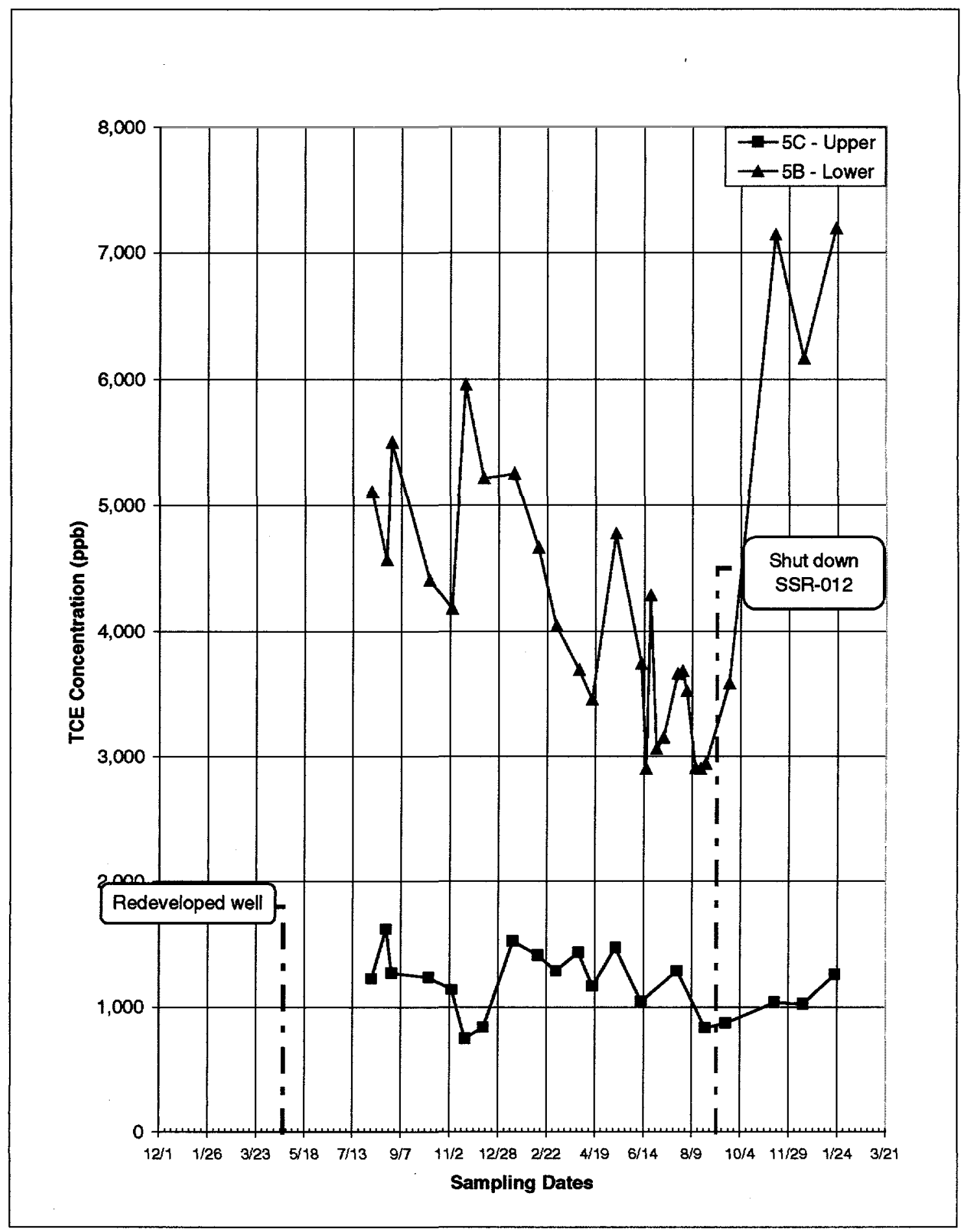

Figure 28: Groundwater sample analytical results - SSM-005 


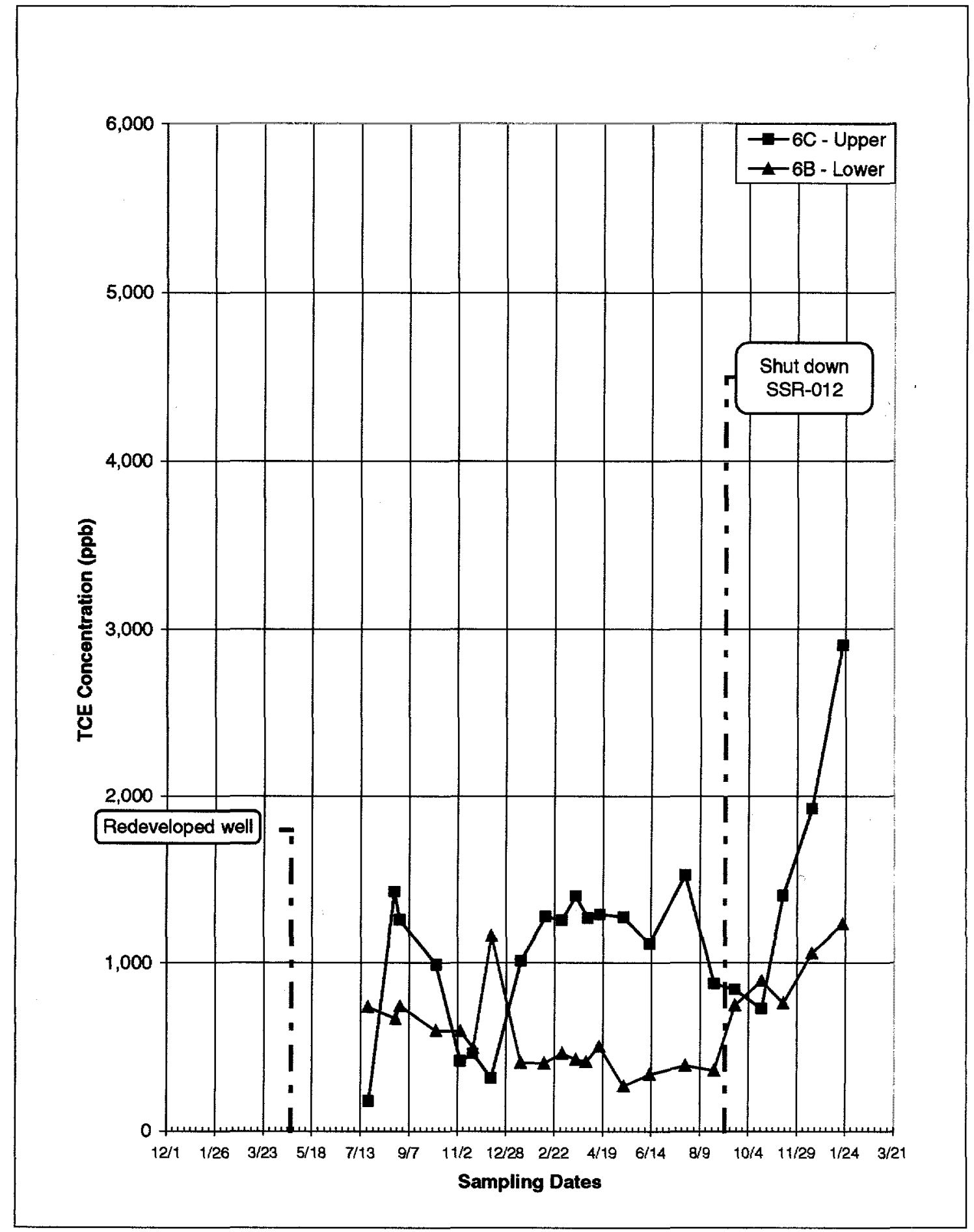

Figure 29: Groundwater sample analytical results - SSM-006 


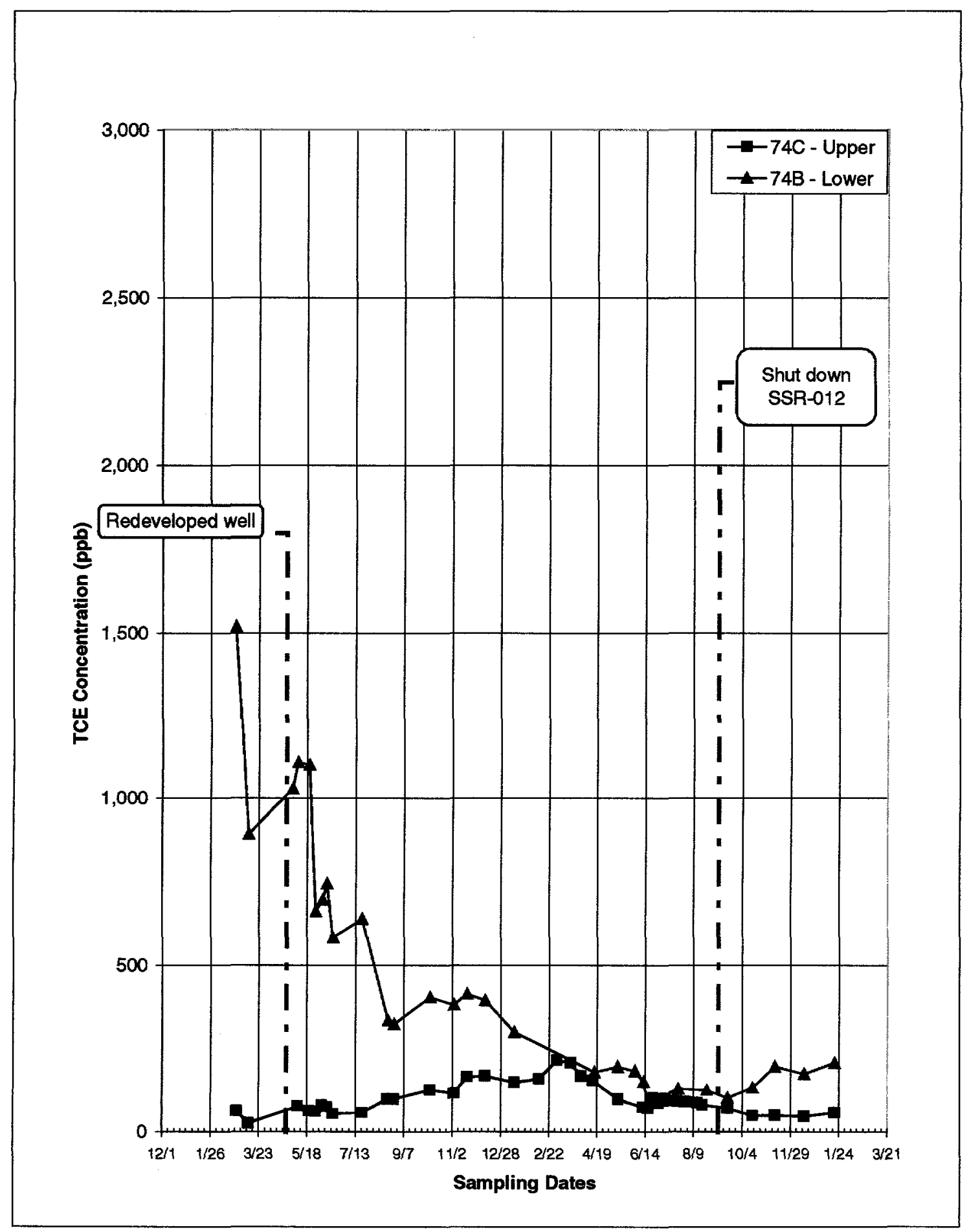

Figure 30: Groundwater sample analytical results - MSB-074 


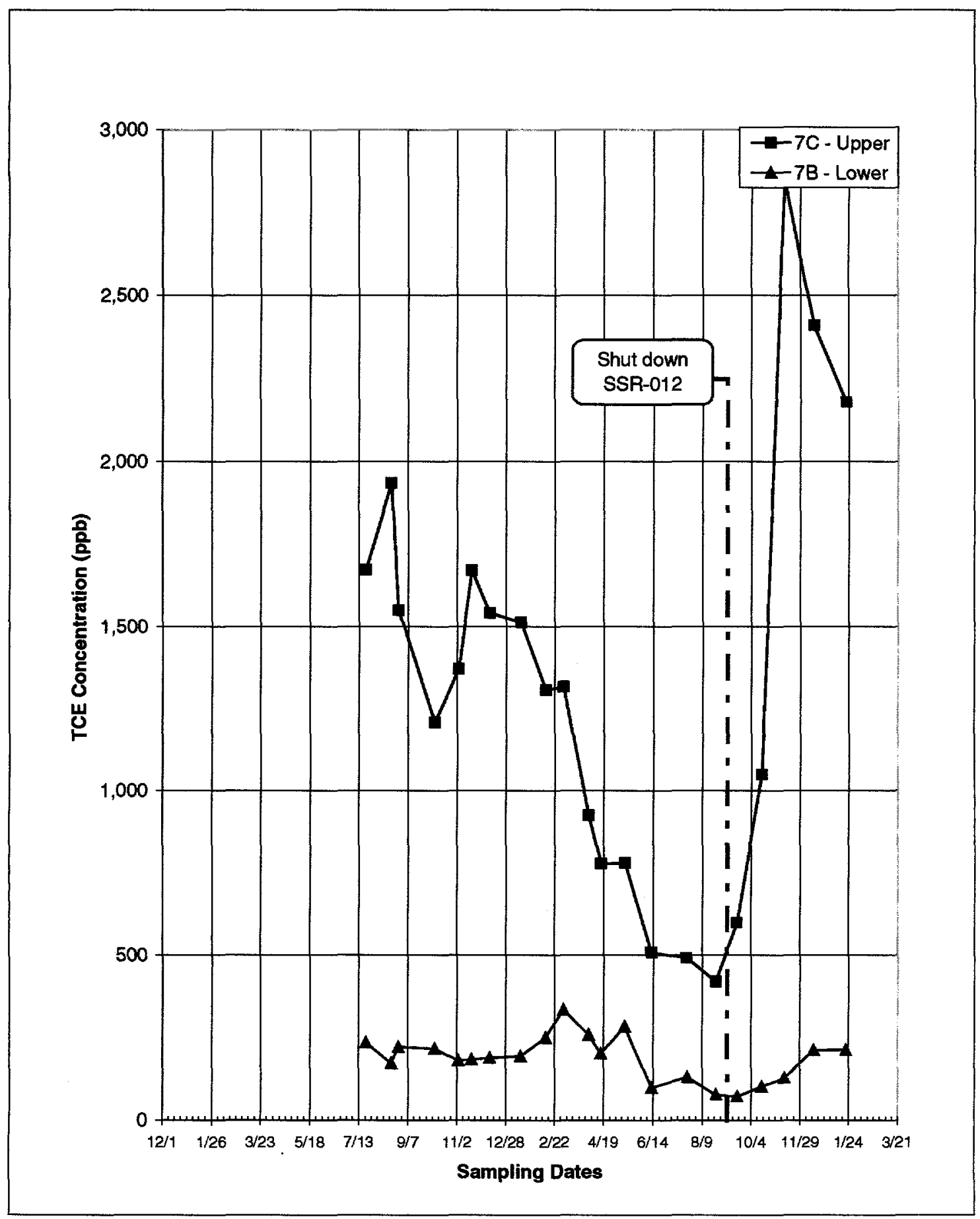

Figure 31: Groundwater sample analytical results - SSM-007 


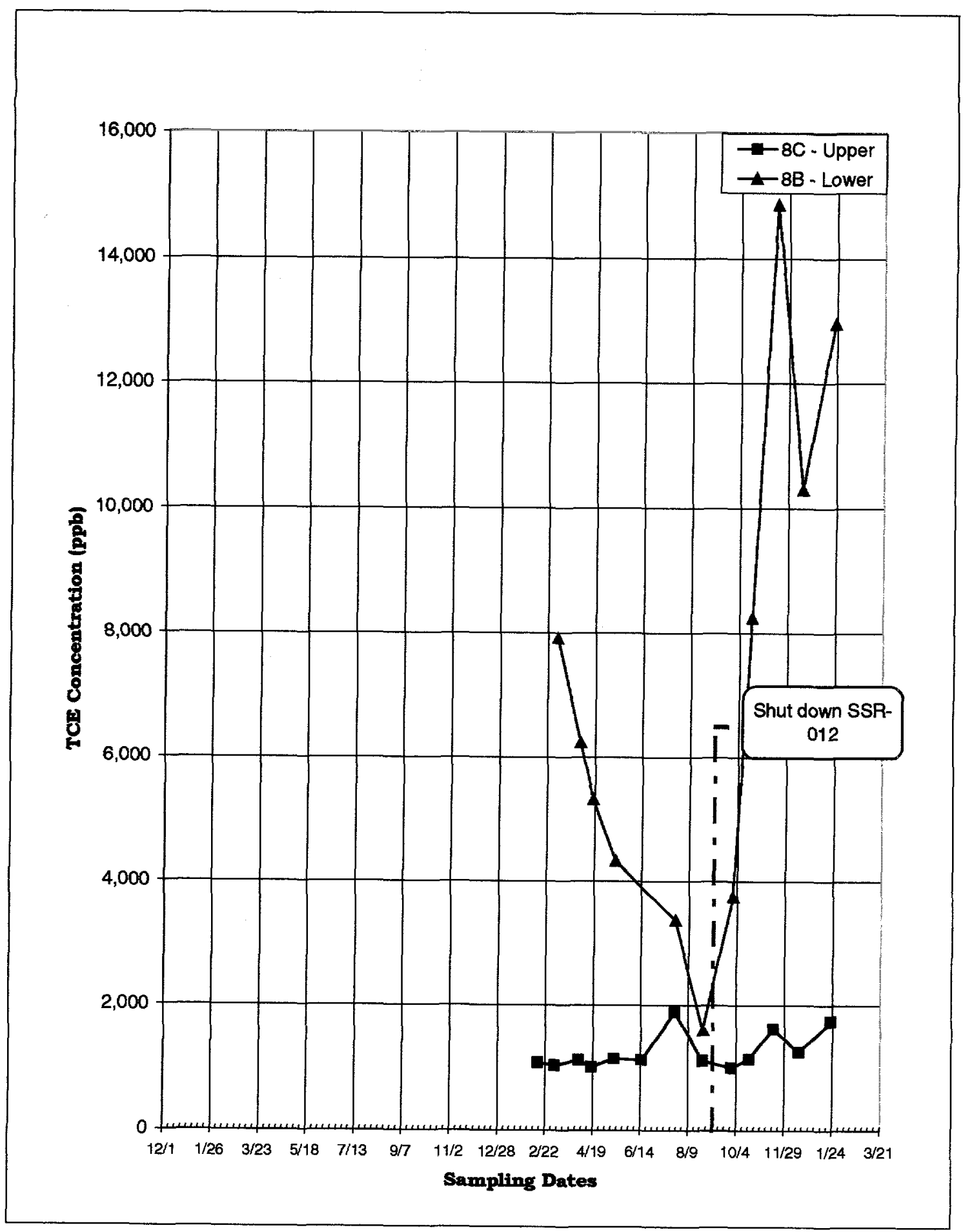

Figure 32: Groundwater sample analytical results - SSM-008 


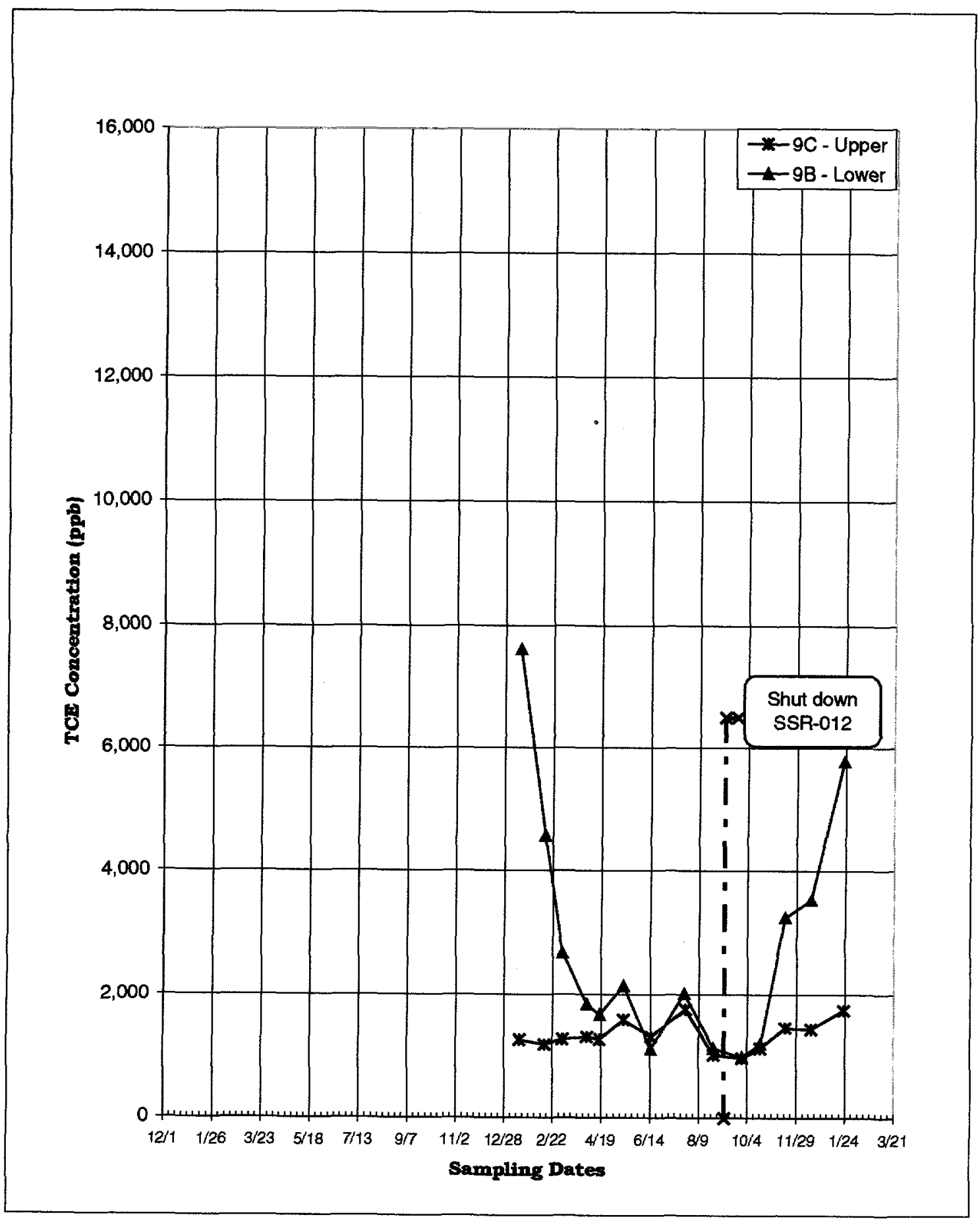

Figure 33: Groundwater sample analytical results - SSM-009 


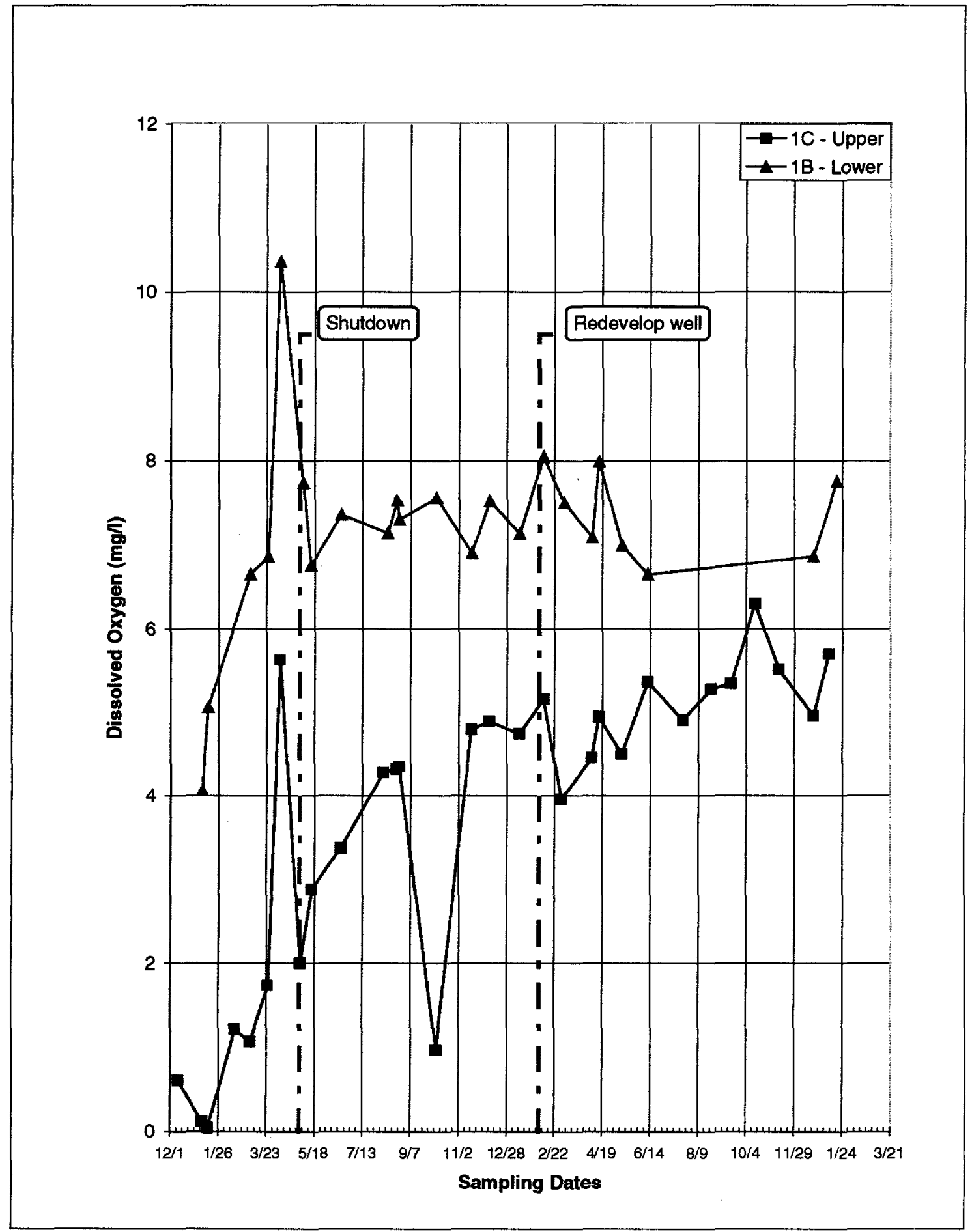

Figure 34: Dissolved Oxygen concentration - SSM-001 


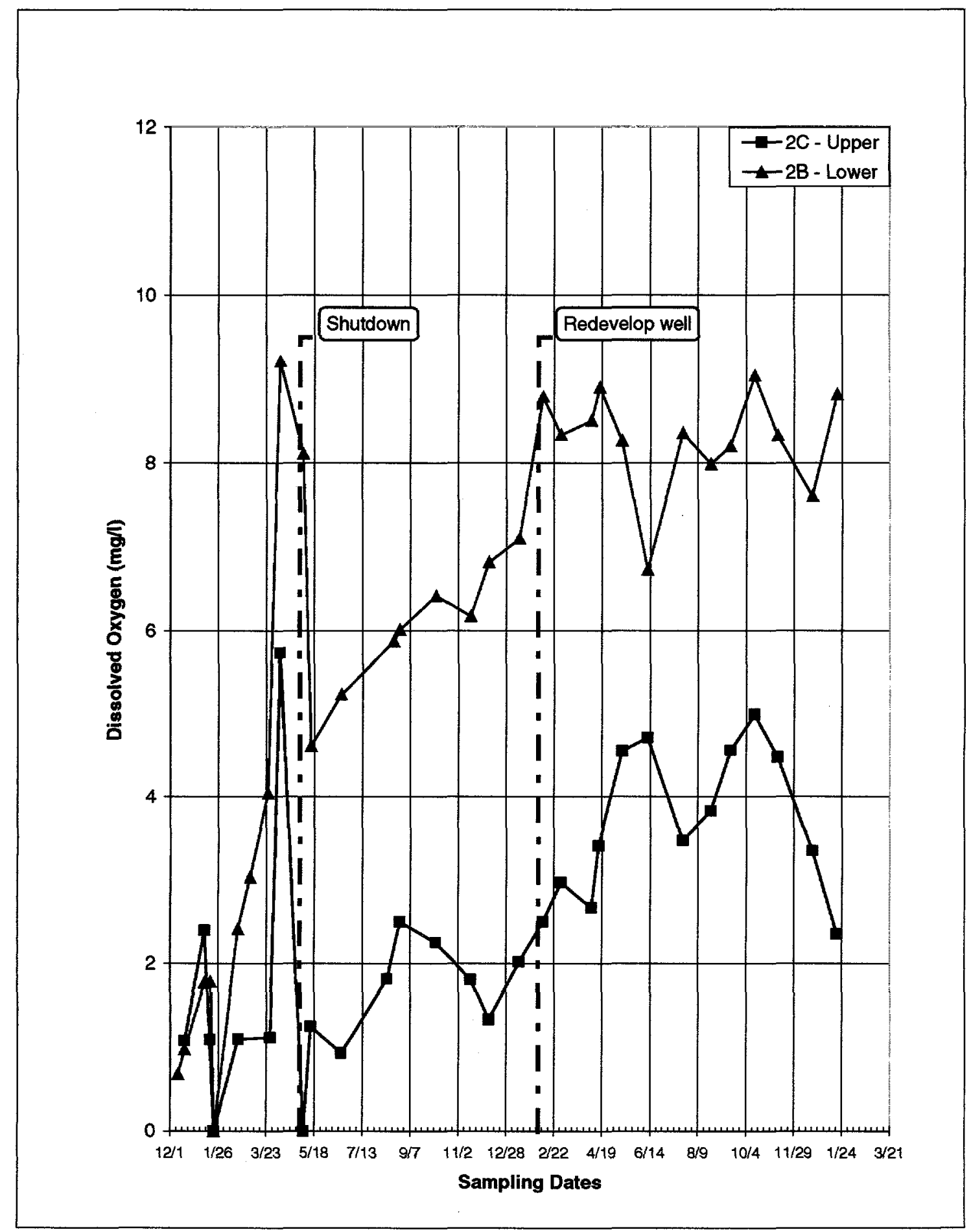

Figure 35: Dissolved Oxygen concentration - SSM-002 


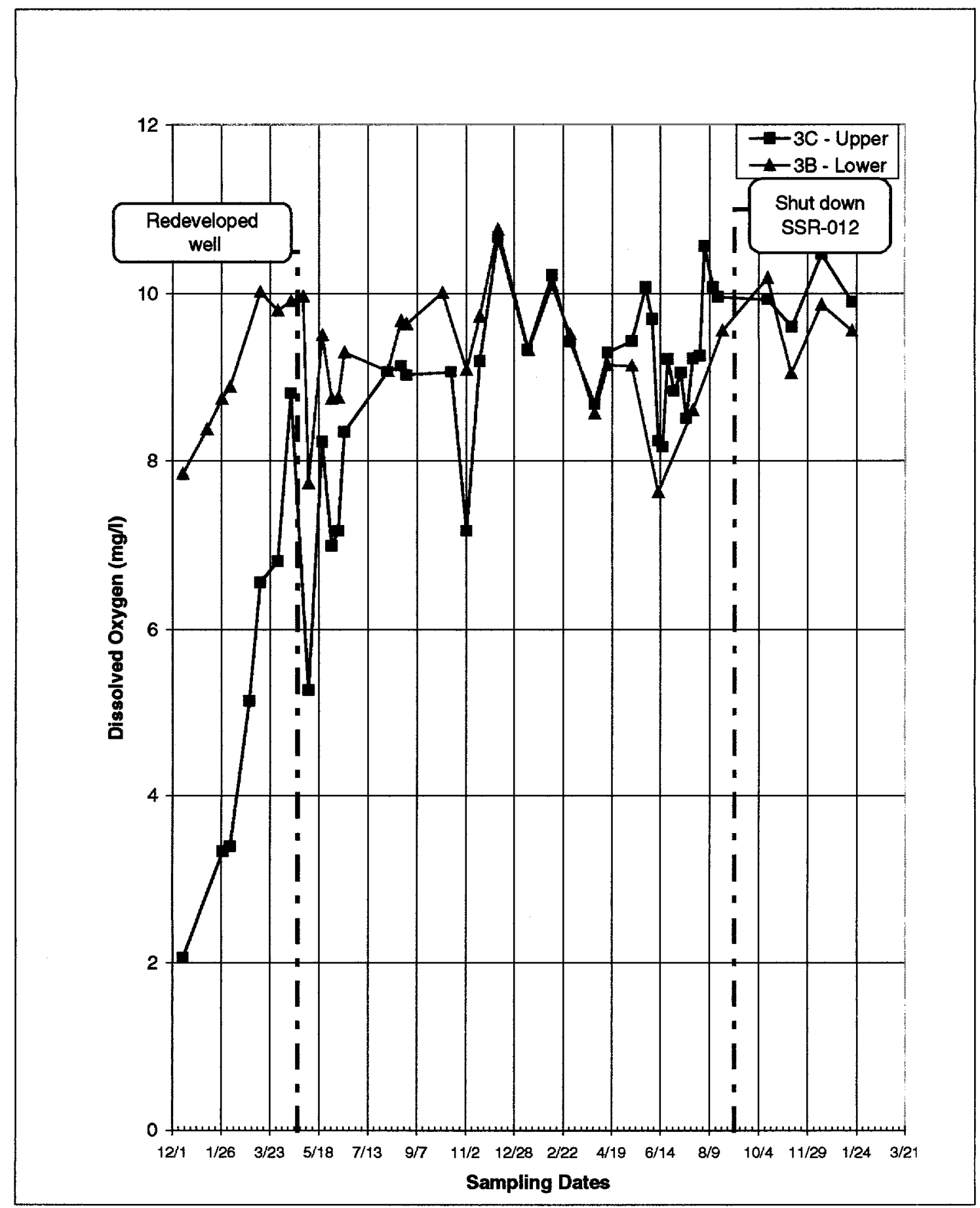

Figure 36: Dissolved Oxygen concentration - SSM-003 


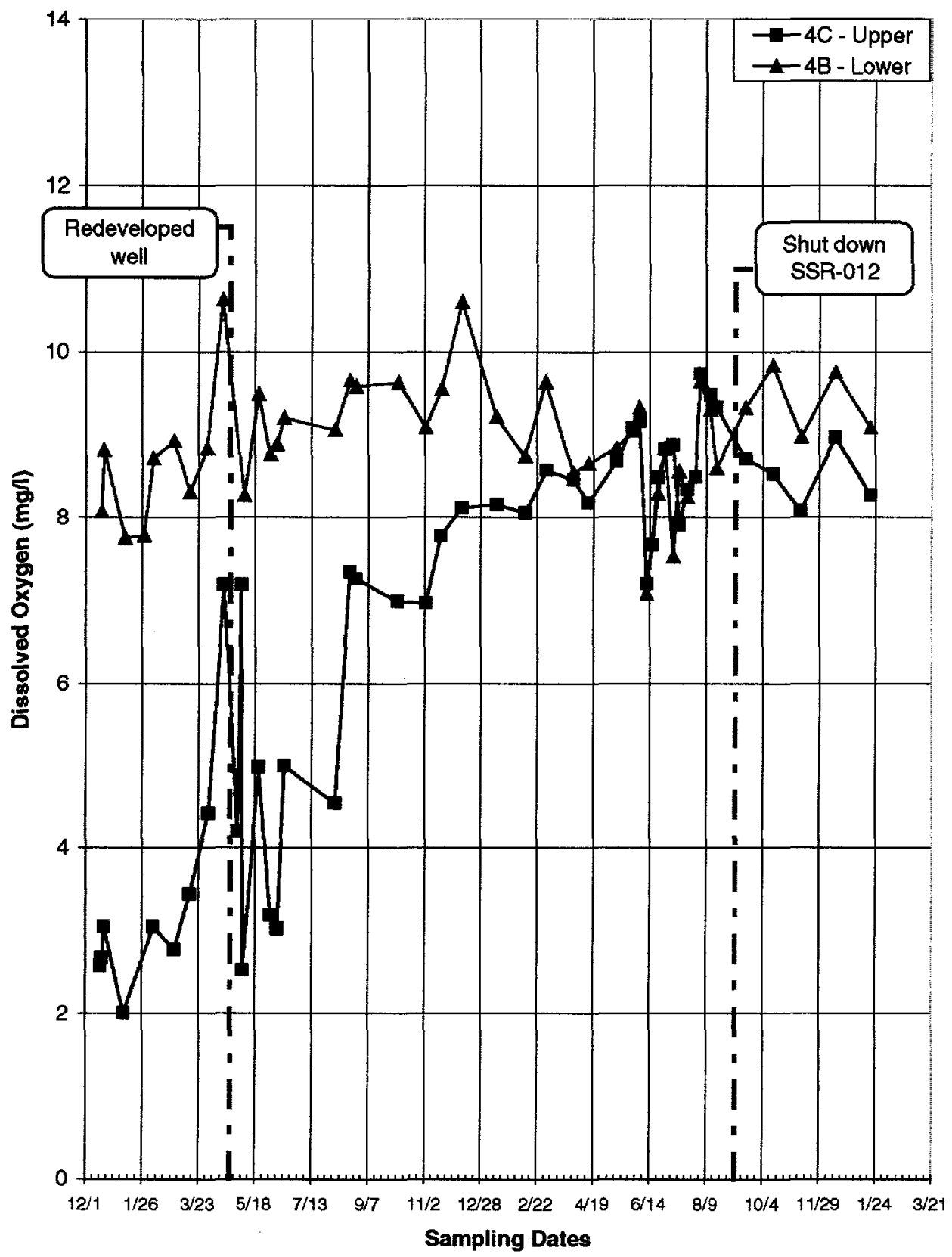

Figure 37: Dissolved Oxygen concentration - SSM-004 


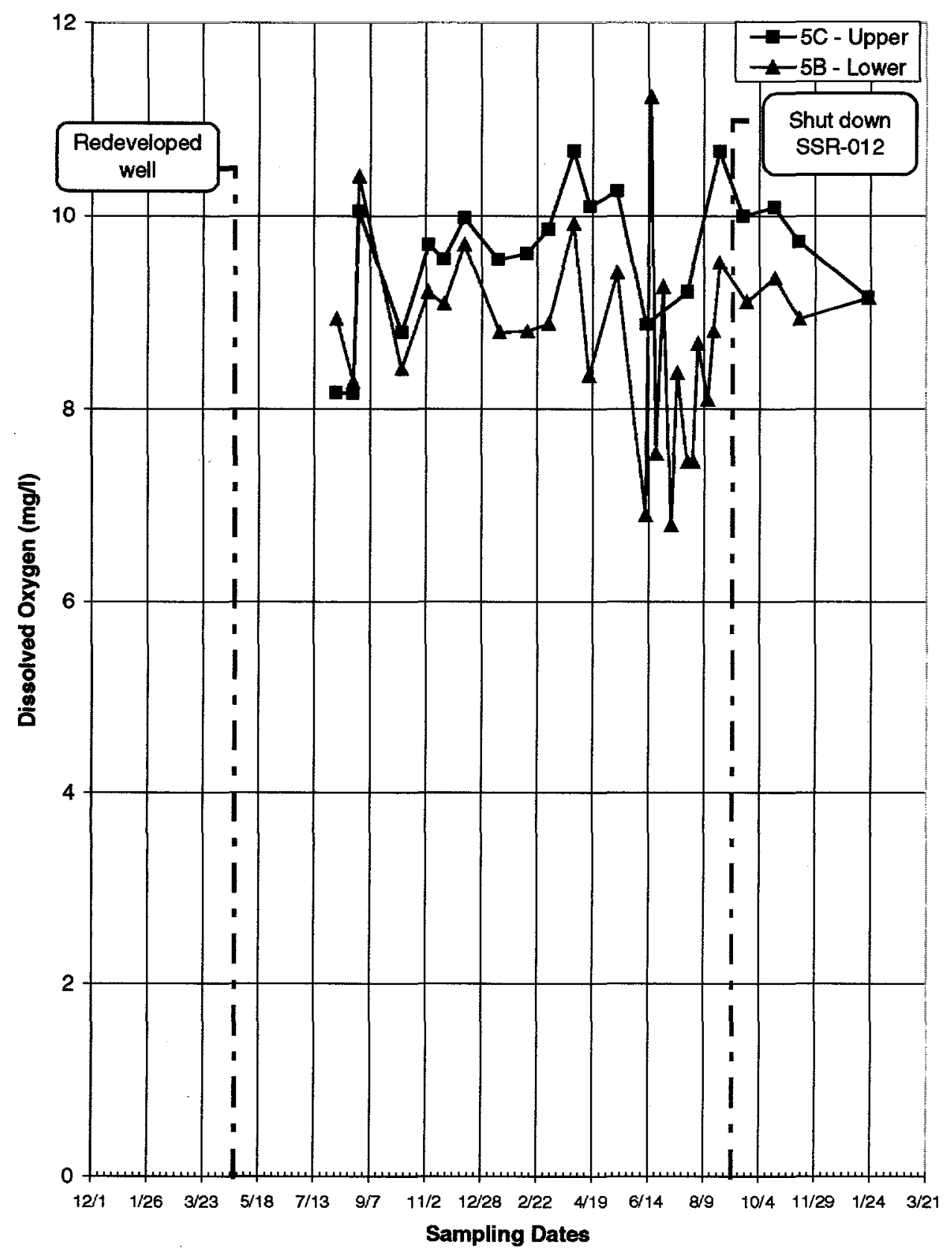

Figure 38: Dissolved Oxygen concentration - SSM-005 


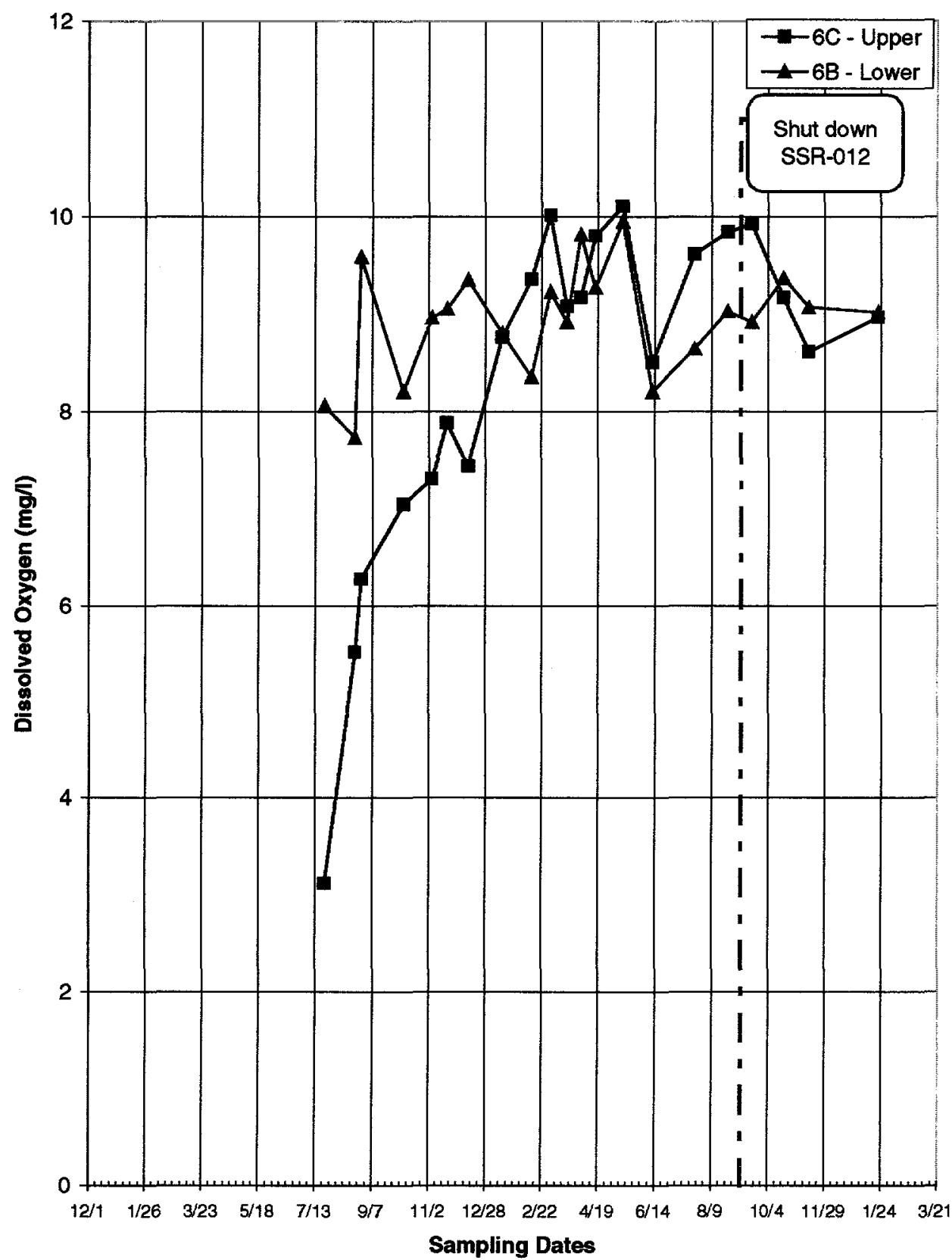

Figure 39: Dissolved Oxygen concentration - SSM-006 


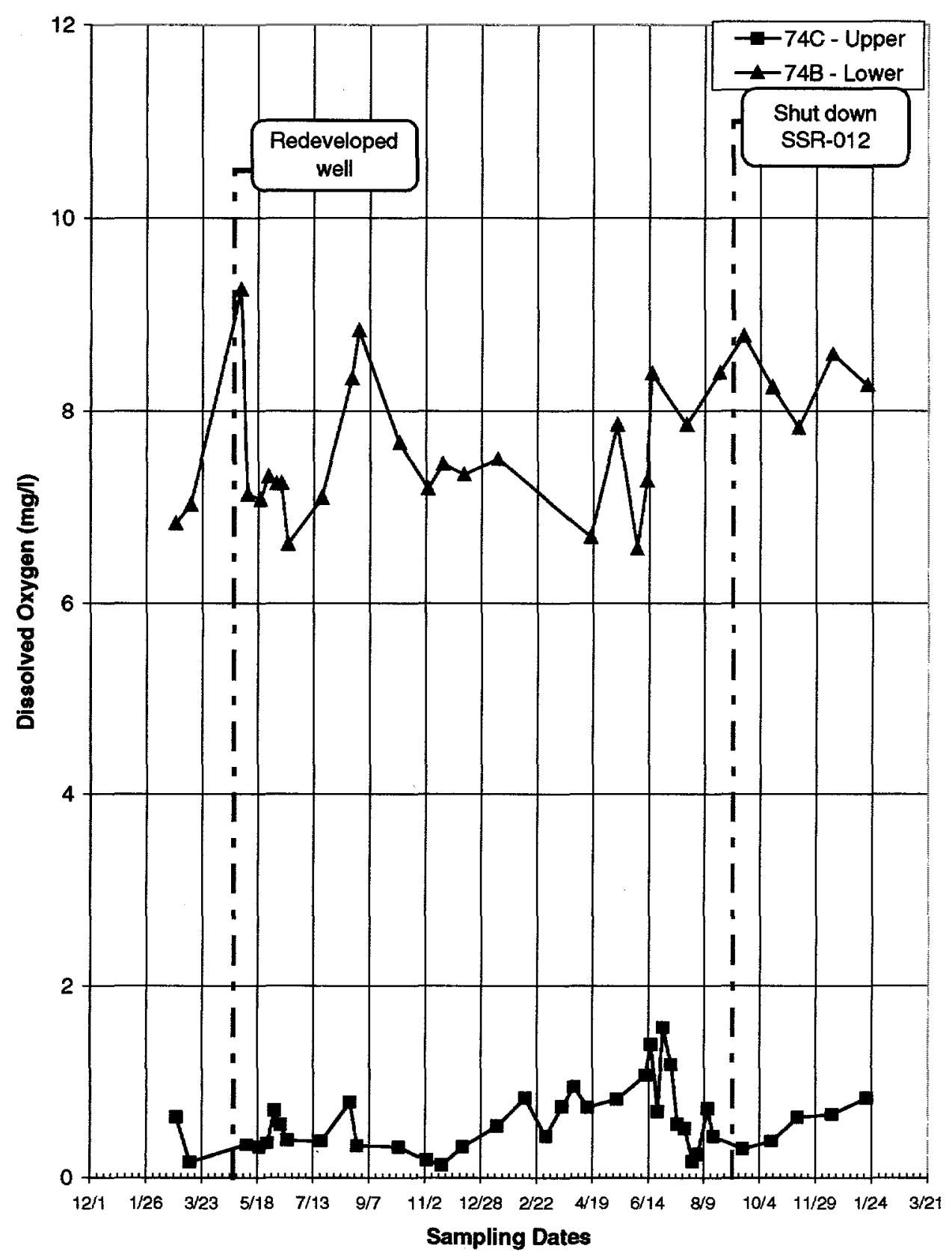

Figure 40: Dissolved Oxygen concentration - MSB-074 


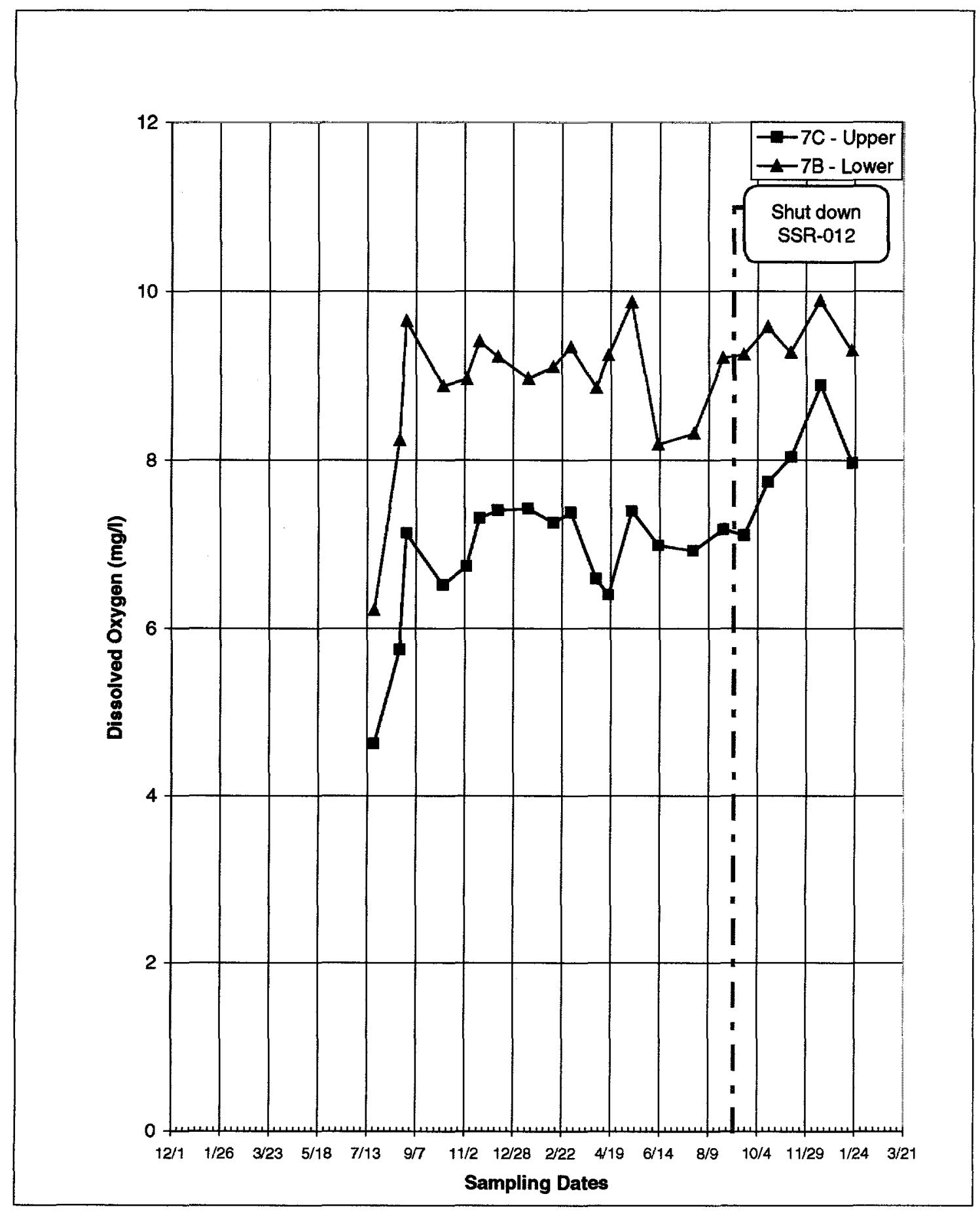

Figure 41: Dissolved Oxygen concentration - SSM-007 


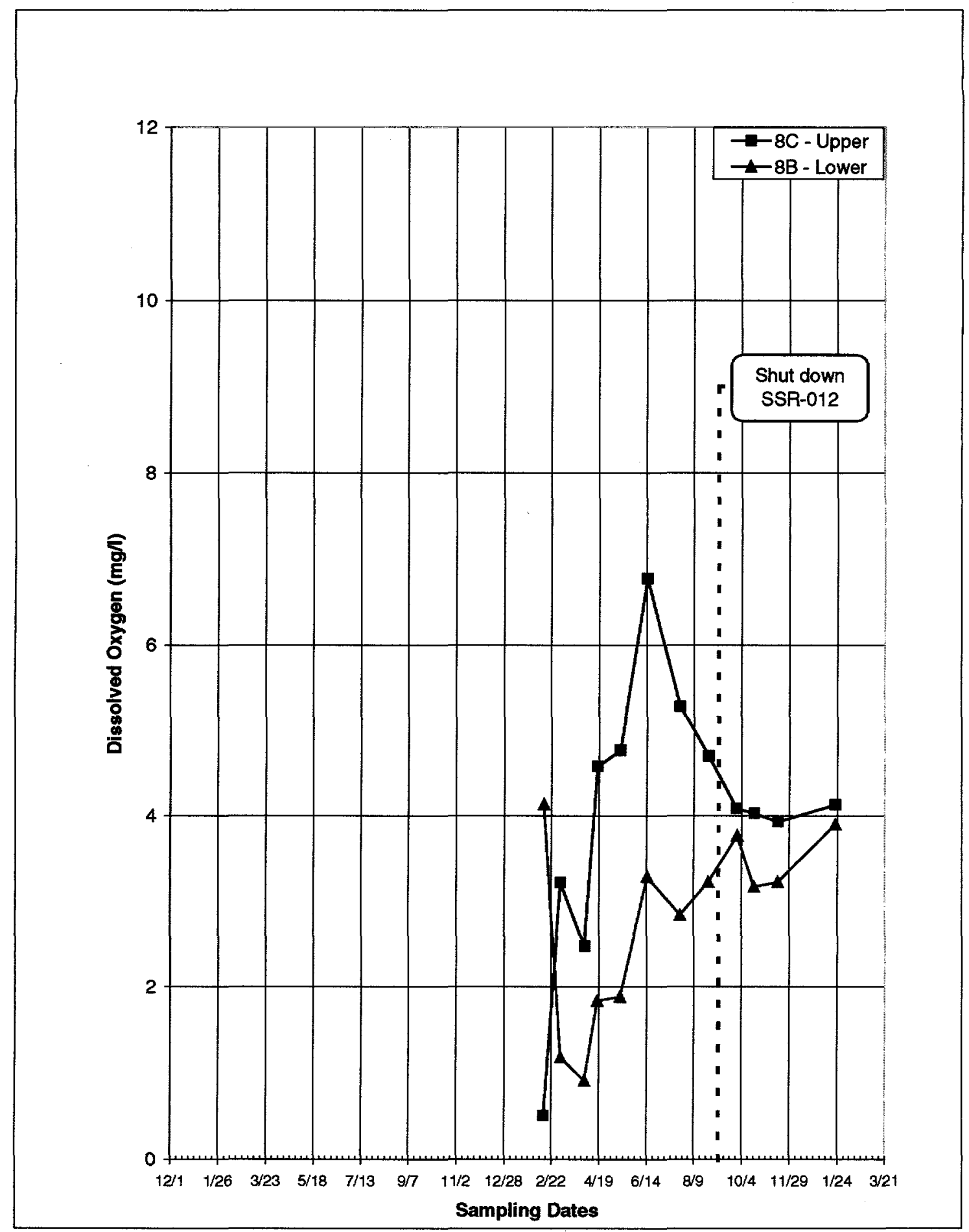

Figure 42: Dissolved Oxygen concentration - SSM-008 


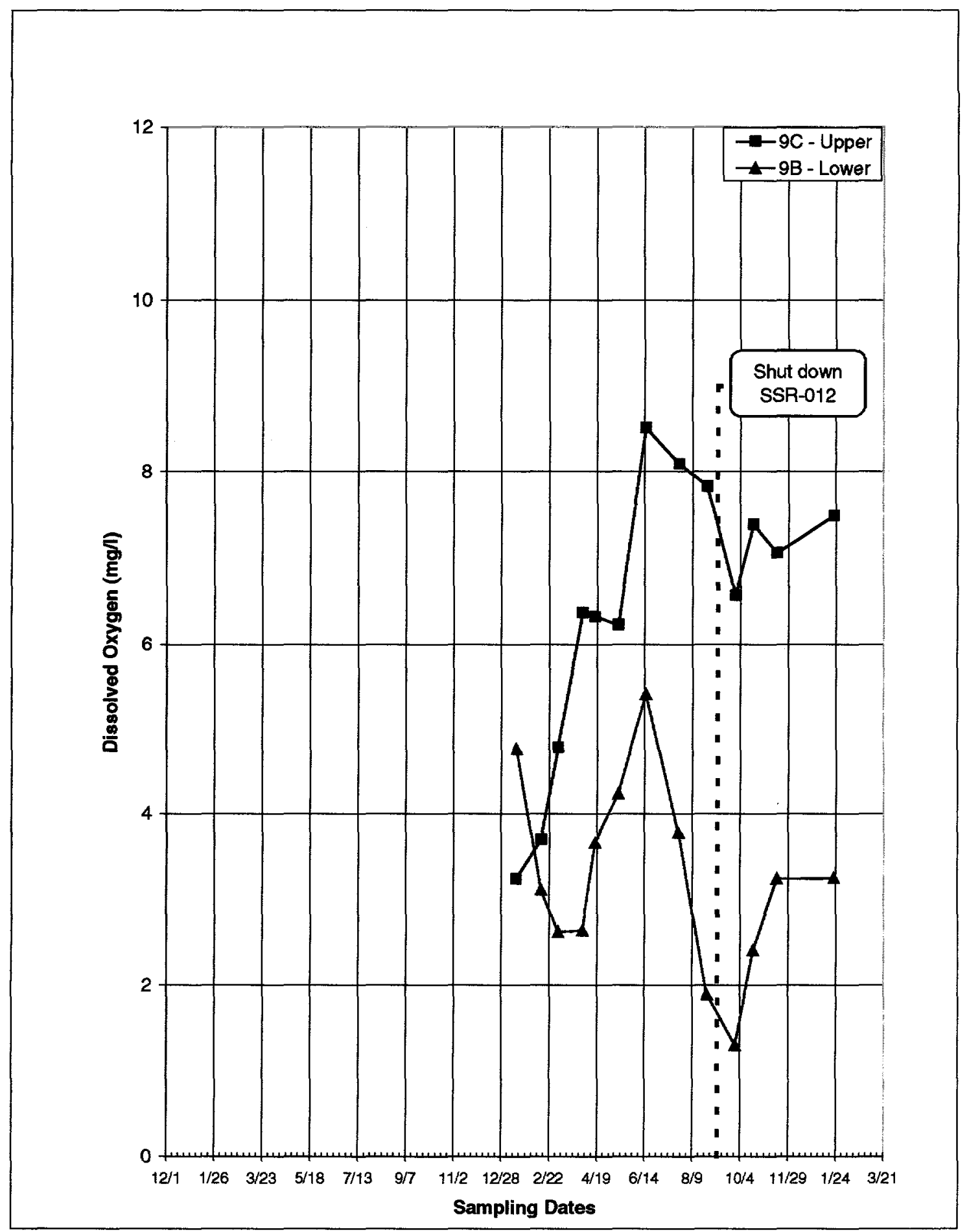

Figure 43: Dissolved Oxygen concentration - SSM-009 
Table 4: Results of groundwater sampling - Wells SSM-001 and SSM-002

\begin{tabular}{|c|c|c|c|c|c|c|c|c|c|c|c|}
\hline \multicolumn{3}{|c|}{ SSM-001 B } & \multicolumn{3}{|c|}{ SSM-001 C } & & \multicolumn{2}{|c|}{ SSM-002 B } & \multicolumn{3}{|c|}{ SSM-002 C } \\
\hline & D.0. & TCE & & D.O. & TCE & & D.O. & TCE & & $\mathbf{D}$ & TCE \\
\hline Date & $\mathrm{mg} / \mathrm{L}$ & ppb & Date & $\mathrm{mg} / \mathrm{L}$ & ppb & Date & $\mathrm{mg} / \mathrm{L}$ & ppb & Date & $m g / L$ & ppb \\
\hline $12 / 10 / 96$ & & & $12 / 10 / 96$ & 0.6 & 8 & $12 / 10 / 96$ & 0.7 & & $11 / 27 / 96$ & & 3 \\
\hline $1 / 7 / 97$ & 4.1 & 123 & $1 / 7 / 97$ & 0.1 & 26 & $12 / 18 / 96$ & 1.0 & & $12 / 18 / 96$ & 1.1 & 19 \\
\hline $1 / 14 / 97$ & 5.1 & & $1 / 14 / 97$ & & & $1 / 3 / 97$ & & 483 & $1 / 3 / 97$ & & 22 \\
\hline $1 / 20 / 97$ & & 111 & $1 / 20 / 97$ & & 29 & $1 / 6197$ & & 475 & $1 / 10 / 97$ & 2.4 & 45 \\
\hline $2 / 14 / 97$ & & 135 & $2 / 14 / 97$ & 1.2 & 34 & $1 / 10 / 97$ & 1.8 & 439 & $1 / 16 / 97$ & 1.1 & 27 \\
\hline $3 / 4 / 97$ & 6.7 & 114 & $3 / 4 / 97$ & 1.1 & 20 & $1 / 17 / 97$ & 1.8 & 313 & $1 / 21 / 97$ & N/A & 29 \\
\hline $3 / 25 / 97$ & 6.9 & 125 & $3 / 25 / 97$ & 1.7 & 38 & $1 / 21 / 97$ & N/A & 200 & $2 / 18 / 97$ & 1.1 & 28 \\
\hline $4 / 8 / 97$ & 10.4 & 116 & $4 / 8 / 97$ & 5.6 & 59 & $2 / 18 / 97$ & 2.4 & 464 & $3 / 4 / 97$ & & 21 \\
\hline $5 / 5 / 97$ & 7.7 & 141 & $5 / 2 / 97$ & 2.0 & 80 & $3 / 4 / 97$ & 3.0 & 339 & $3 / 27 / 97$ & 1.1 & 50 \\
\hline $5 / 14 / 97$ & 6.8 & 200 & $5 / 15 / 97$ & 2.9 & 77 & $3 / 25 / 97$ & 4.0 & 477 & $4 / 8 / 97$ & 5.7 & \\
\hline $6 / 18 / 97$ & 7.4 & 93 & $6 / 18 / 97$ & 3.4 & 58 & $4 / 8 / 97$ & 9.2 & 518 & $5 / 5 / 97$ & N/A & 60 \\
\hline $8 / 11 / 97$ & 7.1 & 143 & $8 / 6 / 97$ & 4.3 & 108 & $5 / 5 / 97$ & 8.1 & 414 & $5 / 13 / 97$ & 1.3 & 61 \\
\hline $8 / 22 / 97$ & 7.5 & 107 & $8 / 21 / 97$ & 4.3 & 61 & $5 / 14 / 97$ & 4.6 & 531 & $6 / 18 / 97$ & 0.9 & 64 \\
\hline $8 / 25 / 97$ & 7.3 & 116 & $8 / 25 / 97$ & 4.4 & 57 & $6 / 18 / 97$ & 5.2 & 423 & $8 / 11 / 97$ & 1.8 & 56 \\
\hline $10 / 7 / 97$ & 7.6 & 179 & $10 / 7 / 97$ & 1.0 & 89 & $8 / 19 / 97$ & 5.9 & 387 & $8 / 22 / 97$ & & 56 \\
\hline $11 / 17 / 97$ & 6.9 & 190 & $11 / 17 / 97$ & 4.8 & 62 & $8 / 26 / 97$ & 6.0 & 400 & $8 / 26 / 97$ & 2.5 & 48 \\
\hline $12 / 8 / 97$ & 7.5 & 196 & $12 / 8 / 97$ & 4.9 & 60 & $10 / 7 / 97$ & 6.4 & 424 & $10 / 7 / 97$ & 2.3 & 63 \\
\hline $1 / 12 / 98$ & 7.1 & 251 & $1 / 12 / 98$ & 4.8 & 75 & $11 / 17 / 97$ & 6.2 & 453 & $11 / 17 / 97$ & 1.8 & 54 \\
\hline $2 / 9 / 98$ & 8.1 & 215 & $2 / 9 / 98$ & 5.2 & 53 & $12 / 8 / 97$ & 6.8 & 126 & $12 / 8 / 97$ & 1.3 & 57 \\
\hline $3 / 5 / 98$ & 7.5 & 680 & $3 / 2 / 98$ & 4.0 & 54 & $1 / 12 / 98$ & 7.1 & 397 & $1 / 12 / 98$ & 2.0 & 69 \\
\hline $4 / 7 / 98$ & 7.1 & 524 & $4 / 7 / 98$ & 4.5 & 80 & $2 / 9 / 98$ & 8.8 & 472 & $2 / 9 / 98$ & 2.5 & 40 \\
\hline $4 / 15 / 98$ & 8.0 & 429 & $4 / 15 / 98$ & 5.0 & 91 & $3 / 2 / 98$ & 8.3 & 473 & $3 / 2 / 98$ & 3.0 & 14 \\
\hline $5 / 12 / 98$ & 7.0 & 282 & $5 / 12 / 98$ & 4.5 & 103 & $4 / 7 / 98$ & 8.5 & 697 & $4 / 7 / 98$ & 2.7 & 15 \\
\hline $6 / 11 / 98$ & 6.7 & 292 & $6 / 11 / 98$ & 5.4 & 123 & $4 / 16 / 98$ & 8.9 & 599 & $4 / 15 / 98$ & 3.4 & 10 \\
\hline $12 / 21 / 98$ & 6.9 & 152 & $7 / 22 / 98$ & 4.9 & 150 & $5 / 12 / 98$ & 8.3 & 614 & $5 / 12 / 98$ & 4.6 & 13 \\
\hline $1 / 18 / 99$ & 7.8 & 206 & $8 / 24 / 98$ & 5.3 & 96 & $6 / 11 / 98$ & 6.7 & 540 & $6 / 11 / 98$ & 4.7 & 19 \\
\hline & & & $9 / 16 / 98$ & 5.4 & 161 & $7 / 22 / 98$ & 8.4 & 624 & $7 / 22 / 98$ & 3.5 & 13 \\
\hline & & & $10 / 14 / 98$ & 6.3 & 164 & $8 / 24 / 98$ & 8.0 & 509 & $8 / 24 / 98$ & 3.8 & 8 \\
\hline & & & $11 / 10 / 98$ & 5.5 & 196 & $9 / 16 / 98$ & 8.2 & 422 & $9 / 16 / 98$ & 4.6 & 16 \\
\hline & & & $12 / 21 / 98$ & 5.0 & 194 & $10 / 14 / 98$ & 9.0 & 459 & $10 / 14 / 98$ & 5.0 & 6 \\
\hline & & & $1 / 8 / 99$ & 5.7 & 221 & $11 / 10 / 98$ & 8.3 & 445 & $11 / 10 / 98$ & 4.5 & 5 \\
\hline & & & & & & $12 / 21 / 98$ & 7.6 & 351 & $12 / 21 / 98$ & 3.4 & 40 \\
\hline & & & & & & $1 / 18 / 99$ & 8.8 & 412 & $1 / 18 / 99$ & 2.4 & 113 \\
\hline
\end{tabular}


Table 5: Results of groundwater sampling - Wells SSM-003 and SSM-004

\begin{tabular}{|c|c|c|c|c|c|c|c|c|c|c|c|}
\hline \multicolumn{3}{|c|}{ SSM-003 B } & \multicolumn{3}{|c|}{ SSM-003 C } & \multicolumn{3}{|c|}{ SSM-004 B } & \multicolumn{3}{|c|}{ SSM-004 C } \\
\hline & D.O. & TCE & & D.o. & TCE & & D.O. & TCE & & D.O. & TCE \\
\hline Date & $\mathrm{mg} / \mathrm{L}$ & ppb & Date & $\mathrm{mg} / \mathrm{L}$ & ppb & Date & $\mathrm{mg} / \mathrm{L}$ & ppb & Date & $\mathrm{mg} / \mathrm{L}$ & ppb \\
\hline $12 / 13 / 96$ & 7.9 & & $12 / 13 / 96$ & 2.1 & & $12 / 17 / 96$ & 8.1 & & $12 / 16 / 96$ & 2.6 & \\
\hline $1 / 10 / 97$ & 8.4 & 5,576 & $1 / 28 / 97$ & 3.3 & 11,882 & $12 / 19 / 96$ & 8.8 & & $12 / 17 / 96$ & 2.7 & \\
\hline $1 / 27 / 97$ & 8.8 & 5,304 & $2 / 5 / 97$ & 3.4 & 8,226 & $1 / 3 / 97$ & & 10,364 & $12 / 19 / 96$ & 3.0 & \\
\hline $2 / 5 / 97$ & 8.9 & 5,148 & $2 / 27 / 97$ & 5.1 & 4,638 & $1 / 9 / 97$ & 7.8 & 10,249 & $1 / 3 / 97$ & & 3,386 \\
\hline $2 / 26 / 97$ & & 3,792 & $3 / 12 / 97$ & 6.6 & 5,687 & $1 / 28 / 97$ & 7.8 & 16,370 & $1 / 8 / 97$ & 2.0 & 3,055 \\
\hline $3 / 12 / 97$ & 10.0 & 2,630 & $4 / 1 / 97$ & 6.8 & 6,437 & $2 / 6 / 97$ & 8.7 & 14,342 & $1 / 29 / 97$ & & 2,470 \\
\hline $4 / 1 / 97$ & 9.8 & 4,942 & $4 / 16 / 97$ & 8.8 & 5,436 & $2 / 27 / 97$ & 8.9 & 10,479 & $2 / 6 / 97$ & 3.0 & 2,820 \\
\hline $4 / 16 / 97$ & 9.9 & 4,998 & $5 / 6 / 97$ & 5.3 & 1,574 & $3 / 14 / 97$ & 8.3 & 14,110 & $2 / 27 / 97$ & 2.8 & 1,334 \\
\hline $4 / 30 / 97$ & 10.0 & & $5 / 22 / 97$ & 8.2 & 1,861 & $4 / 1 / 97$ & 8.8 & & $3 / 14 / 97$ & 3.4 & 2,042 \\
\hline $5 / 6 / 97$ & 7.7 & 4,942 & $6 / 2 / 97$ & 7.0 & 1,481 & $4 / 16 / 97$ & 10.6 & 10,823 & $4 / 2 / 97$ & 4.4 & 1,920 \\
\hline $5 / 22 / 97$ & 9.5 & 6,827 & $6 / 9 / 97$ & 7.2 & 1,569 & $5 / 1 / 97$ & 8.3 & 8,014 & $4 / 17 / 97$ & 7.2 & 1,249 \\
\hline $6 / 2 / 97$ & 8.8 & 4,597 & $6 / 16 / 97$ & 8.4 & & $5 / 22 / 97$ & 9.5 & 14,952 & $5 / 1 / 97$ & 4.2 & 1,183 \\
\hline $6 / 9 / 97$ & 8.8 & 5,920 & $8 / 4 / 97$ & 9.1 & 889 & $6 / 2 / 97$ & 8.8 & 12,417 & $5 / 5 / 97$ & 7.2 & 1,035 \\
\hline $6 / 16 / 97$ & 9.3 & & $8 / 20 / 97$ & 9.1 & 1,531 & $6 / 9 / 97$ & 8.9 & 11,164 & $5 / 6 / 97$ & 2.5 & 1,063 \\
\hline $8 / 5 / 97$ & 9.1 & 6,655 & $8 / 26 / 97$ & 9.0 & 1,400 & $6 / 16 / 97$ & 9.2 & & $5 / 22 / 97$ & 5.0 & 1,708 \\
\hline $8 / 20 / 97$ & 9.7 & 7,415 & $10 / 16 / 97$ & 9.1 & 827 & $8 / 5 / 97$ & 9.1 & 10,912 & $6 / 2 / 97$ & 3.2 & 1,322 \\
\hline $8 / 26 / 97$ & 9.6 & 5,836 & $11 / 3 / 97$ & 7.2 & 824 & $8 / 20 / 97$ & 9.7 & 10,756 & $6 / 9 / 97$ & 3.0 & 1,339 \\
\hline $10 / 6 / 97$ & 10.0 & 6,625 & $11 / 18 / 97$ & 9.2 & 1,167 & $8 / 26 / 97$ & 9.6 & 9,521 & $6 / 16 / 97$ & 5.0 & \\
\hline $11 / 3 / 97$ & 9.1 & 6,242 & $12 / 9 / 97$ & 10.7 & 1,459 & $10 / 7 / 97$ & 9.6 & 7,973 & $8 / 5 / 97$ & 4.5 & 1,411 \\
\hline $11 / 18 / 97$ & 9.7 & 5,087 & $1 / 12 / 98$ & 9.3 & 1,623 & $11 / 3 / 97$ & 9.1 & 9,831 & $8 / 20 / 97$ & 7.4 & 1,546 \\
\hline $12 / 9 / 97$ & 10.8 & & $2 / 9 / 98$ & 10.2 & 1,419 & $11 / 19 / 97$ & 9.6 & 9,463 & $8 / 26 / 97$ & 7.3 & 1,393 \\
\hline $1 / 13 / 98$ & 9.3 & 6,886 & $3 / 2 / 98$ & 9.4 & 1,393 & $12 / 9 / 97$ & 10.6 & 9,447 & $10 / 6 / 97$ & 7.0 & 837 \\
\hline $2 / 9 / 98$ & 10.1 & 6,359 & $3 / 30 / 98$ & 8.7 & 1,189 & $1 / 13 / 98$ & 9.2 & 12,318 & $11 / 3 / 97$ & 7.0 & 997 \\
\hline $3 / 2 / 98$ & 9.5 & 5,471 & $4 / 14 / 98$ & 9.3 & 1,234 & $2 / 10 / 98$ & 8.7 & 11,831 & $11 / 18 / 97$ & 7.8 & 1,024 \\
\hline $3 / 30 / 98$ & 8.6 & 5,264 & $5 / 12 / 98$ & 9.4 & 1,424 & $3 / 3 / 98$ & 9.6 & 9,782 & $12 / 9 / 97$ & 8.1 & \\
\hline $4 / 14 / 98$ & 9.2 & 4,932 & $5 / 28 / 98$ & 10.1 & 1,286 & $3 / 30 / 98$ & 8.5 & 9,998 & $1 / 13 / 98$ & 8.2 & 1,675 \\
\hline $5 / 12 / 98$ & 9.1 & 7,867 & $6 / 4 / 98$ & 9.7 & 1,289 & $4 / 14 / 98$ & 8.7 & 8,947 & $2 / 10 / 98$ & 8.1 & 1,407 \\
\hline $6 / 11 / 98$ & 7.6 & 5,893 & $6 / 11 / 98$ & 8.2 & 1,248 & $5 / 12 / 98$ & 8.8 & 12,234 & $3 / 3 / 98$ & 8.6 & 1,349 \\
\hline $7 / 21 / 98$ & 8.6 & 5,894 & $6 / 16 / 98$ & 8.2 & 1,082 & $5 / 28 / 98$ & 9.1 & 8,466 & $3 / 30 / 98$ & 8.5 & 1,254 \\
\hline $8 / 24 / 98$ & 9.6 & 5,017 & $6 / 22 / 98$ & 9.2 & & $6 / 4 / 98$ & 9.3 & 10,592 & $4 / 14 / 98$ & 8.2 & 1,186 \\
\hline $10 / 14 / 98$ & 10.2 & 7,130 & $6 / 29 / 98$ & 8.8 & 1,110 & $6 / 11 / 98$ & 7.1 & 11,127 & $5 / 12 / 98$ & 8.7 & 1,517 \\
\hline $11 / 10 / 98$ & 9.1 & 6,175 & $7 / 7 / 98$ & 9.1 & 1,270 & $6 / 22 / 98$ & 8.3 & 9,250 & $5 / 28 / 98$ & 9.1 & 1,297 \\
\hline $12 / 15 / 98$ & 9.9 & 1,866 & $7 / 13 / 98$ & 8.5 & 1,248 & $6 / 29 / 98$ & 8.8 & 12,090 & $6 / 4 / 98$ & 9.2 & 1,303 \\
\hline $1 / 19 / 99$ & 9.6 & 4,223 & $7 / 21 / 98$ & 9.2 & 1,198 & $7 / 7 / 98$ & 7.5 & 11,255 & $6 / 11 / 98$ & 7.2 & 1,231 \\
\hline & & & $7 / 29 / 98$ & 9.3 & 1,192 & $7 / 13 / 98$ & 8.6 & 11,420 & $6 / 16 / 98$ & 7.7 & 1,119 \\
\hline & & & $8 / 3 / 98$ & 10.6 & 1,010 & $7 / 21 / 98$ & 8.3 & 12,376 & $6 / 22 / 98$ & 8.5 & 1,035 \\
\hline & & & $8 / 13 / 98$ & 10.1 & 1,041 & $7 / 29 / 98$ & 8.5 & 12,063 & $6 / 29 / 98$ & 8.8 & 1,287 \\
\hline & & & $8 / 19 / 98$ & 10.0 & 1,074 & $8 / 3 / 98$ & 9.7 & 8,834 & $7 / 7 / 98$ & 8.9 & 1,273 \\
\hline & & & $10 / 14 / 98$ & 9.9 & 1,282 & $8 / 13 / 98$ & 9.3 & 9,856 & $7 / 13 / 98$ & 7.9 & 1,320 \\
\hline & & & $11 / 11 / 98$ & 9.6 & 1,372 & $8 / 19 / 98$ & 8.6 & 9,273 & $7 / 21 / 98$ & 8.3 & 1,279 \\
\hline & & & $12 / 15 / 98$ & 10.5 & 882 & $9 / 17 / 98$ & 9.3 & 6,396 & $7 / 29 / 98$ & 8.5 & 1,372 \\
\hline & & & $1 / 19 / 99$ & 9.9 & 1,214 & $10 / 14 / 98$ & 9.8 & 7,847 & $8 / 3 / 98$ & 9.7 & 1,045 \\
\hline & & & & & & $11 / 11 / 98$ & 9.0 & 12,229 & $8 / 13 / 98$ & 9.5 & 1,091 \\
\hline & & & & & & $12 / 15 / 98$ & 9.8 & 9,382 & $8 / 19 / 98$ & 9.3 & 1,140 \\
\hline & & & & & & $1 / 19 / 99$ & 9.1 & 9,882 & $9 / 17 / 98$ & 8.7 & 950 \\
\hline & & & & & & & & & $10 / 14 / 98$ & 8.5 & 1,332 \\
\hline & & & & & & & & & $11 / 10 / 98$ & 8.1 & 611 \\
\hline & & & & & & & & & $12 / 15 / 98$ & 9.0 & 644 \\
\hline & & & & & & & & & $1 / 19 / 99$ & 8.3 & 1,135 \\
\hline
\end{tabular}


Table 6: Results of groundwater sampling - Wells MSB-074 and SSM-005

\begin{tabular}{|c|c|c|c|c|c|c|c|c|c|c|c|}
\hline \multicolumn{3}{|c|}{ MSB-074B } & \multicolumn{3}{|c|}{ MSB-074 C } & \multicolumn{3}{|c|}{ SSM-005 B } & \multicolumn{3}{|c|}{ SSM-005 C } \\
\hline & D.O. & TCE & & D.o. & TCE & & D.o. & TCE & & D.o. & TCE \\
\hline Date & $\mathrm{mg} / \mathrm{L}$ & ppb & Date & $\mathrm{mg} / \mathrm{L}$ & ppb & Date & $\mathrm{mg} / \mathrm{L}$ & pph & Date & $\mathrm{mg} / \mathrm{L}$ & ppb \\
\hline $2 / 24 / 97$ & 6.8 & 1,522 & $2 / 25 / 97$ & 0.6 & 64 & $8 / 4 / 97$ & 8.9 & 5,107 & $8 / 4 / 97$ & 8.2 & 1,229 \\
\hline $3 / 11 / 97$ & 7.0 & 894 & $3 / 11 / 97$ & 0.2 & 27 & $8 / 21 / 97$ & 8.3 & 4,565 & $8 / 21 / 97$ & 8.2 & 1,620 \\
\hline $5 / 1 / 97$ & 9.3 & 1,030 & $5 / 7 / 97$ & 0.3 & 77 & $8 / 27 / 97$ & 10.4 & 5,501 & $8 / 27 / 97$ & 10.1 & 1,276 \\
\hline $5 / 7 / 97$ & 7.1 & 1,109 & $5 / 20 / 97$ & 0.3 & 64 & $10 / 9 / 97$ & 8.4 & 4,407 & $10 / 9 / 97$ & 8.8 & 1,241 \\
\hline $5 / 20 / 97$ & 7.1 & 1,101 & $5 / 28 / 97$ & 0.4 & 62 & $11 / 4 / 97$ & 9.2 & 4,180 & $11 / 5 / 97$ & 9.7 & 1,138 \\
\hline $5 / 28 / 97$ & 7.3 & 662 & $6 / 4 / 97$ & 0.7 & 80 & $11 / 20 / 97$ & 9.1 & 5,957 & $11 / 20 / 97$ & 9.6 & 750 \\
\hline $6 / 5 / 97$ & 7.2 & 696 & $6 / 10 / 97$ & 0.6 & 76 & $12 / 11 / 97$ & 9.7 & 5,218 & $12 / 11 / 97$ & 10.0 & 840 \\
\hline $6 / 10 / 97$ & 7.3 & 745 & $6 / 17 / 97$ & 0.4 & 55 & $1 / 15 / 98$ & 8.8 & 5,252 & $1 / 14 / 98$ & 9.6 & 1,523 \\
\hline $6 / 17 / 97$ & 6.6 & 583 & $7 / 21 / 97$ & 0.4 & 58 & $2 / 12 / 98$ & 8.8 & 4,663 & $2 / 12 / 98$ & 9.6 & 1,413 \\
\hline $7 / 21 / 97$ & 7.1 & 639 & $8 / 19 / 97$ & 0.8 & 99 & $3 / 5 / 98$ & 8.9 & 4,045 & $3 / 5 / 98$ & 9.9 & 1,290 \\
\hline $8 / 20 / 97$ & 8.3 & 334 & $8 / 26 / 97$ & 0.3 & 99 & $3 / 31 / 98$ & 9.9 & 3,690 & $3 / 31 / 98$ & 10.7 & 1,434 \\
\hline $8 / 27 / 97$ & 8.8 & 324 & $10 / 7 / 97$ & 0.3 & 127 & $4 / 15 / 98$ & 8.3 & 3,454 & $4 / 16 / 98$ & 10.1 & 1,168 \\
\hline $10 / 7 / 97$ & 7.7 & 405 & $11 / 4 / 97$ & 0.2 & 117 & $5 / 13 / 98$ & 9.4 & 4,776 & $5 / 13 / 98$ & 10.3 & 1,471 \\
\hline $11 / 4 / 97$ & 7.2 & 382 & $11 / 19 / 97$ & 0.1 & 166 & $6 / 11 / 98$ & 6.9 & 3,741 & $6 / 12 / 98$ & 8.9 & 1,043 \\
\hline $11 / 19 / 97$ & 7.5 & 414 & $12 / 10 / 97$ & 0.3 & 169 & $6 / 17 / 98$ & 11.2 & 2,901 & $7 / 23 / 98$ & 9.2 & 1,289 \\
\hline $12 / 10 / 97$ & 7.3 & 395 & $1 / 13 / 98$ & 0.5 & 149 & $6 / 22 / 98$ & 7.5 & 4,283 & $8 / 25 / 98$ & 10.7 & 837 \\
\hline $1 / 13 / 98$ & 7.5 & 300 & $2 / 10 / 98$ & 0.8 & 160 & $6 / 29 / 98$ & 9.3 & 3,057 & $9 / 18 / 98$ & 10.0 & 873 \\
\hline $4 / 16 / 98$ & 6.7 & 180 & $3 / 3 / 98$ & 0.4 & 216 & $7 / 7 / 98$ & 6.8 & 3,149 & $10 / 19 / 98$ & 10.1 & \\
\hline $5 / 13 / 98$ & 7.9 & 196 & $3 / 19 / 98$ & 0.7 & 208 & $7 / 13 / 98$ & 8.4 & & $11 / 13 / 98$ & 9.7 & 1,036 \\
\hline $6 / 2 / 98$ & 6.6 & 183 & $3 / 31 / 98$ & 1.0 & 168 & $7 / 23 / 98$ & 7.5 & 3,662 & $12 / 16 / 98$ & 0.0 & 1,025 \\
\hline $6 / 12 / 98$ & 7.3 & 151 & $4 / 14 / 98$ & 0.7 & 155 & $7 / 29 / 98$ & 7.5 & 3,683 & $1 / 21 / 99$ & 9.2 & 1,260 \\
\hline $6 / 17 / 98$ & 8.4 & 88 & $5 / 13 / 98$ & 0.8 & 100 & $8 / 3 / 98$ & 8.7 & 3,522 & & & \\
\hline $7 / 22 / 98$ & 7.9 & 130 & $6 / 11 / 98$ & 1.1 & 75 & $8 / 13 / 98$ & 8.1 & 2,904 & & & \\
\hline $8 / 24 / 98$ & 8.4 & 126 & $6 / 17 / 98$ & 1.4 & 71 & $8 / 19 / 98$ & 8.8 & 2,902 & & & \\
\hline $9 / 17 / 98$ & 8.8 & 103 & $6 / 23 / 98$ & 0.7 & 103 & $8 / 25 / 98$ & 9.5 & 2,939 & & & \\
\hline $10 / 16 / 98$ & 8.3 & 133 & $6 / 29 / 98$ & 1.6 & 88 & $9 / 21 / 98$ & 9.1 & 3,584 & & & \\
\hline $11 / 11 / 98$ & 7.8 & 196 & $7 / 7 / 98$ & 1.2 & 101 & $10 / 19 / 98$ & 9.4 & & & & \\
\hline $12 / 15 / 98$ & 8.6 & 175 & $7 / 13 / 98$ & 0.6 & 94 & $11 / 13 / 98$ & 8.9 & 7,141 & & & \\
\hline $1 / 19 / 99$ & 8.3 & 208 & $7 / 21 / 98$ & 0.5 & 92 & $12 / 16 / 98$ & 0.0 & 6,164 & & & \\
\hline & & & $7 / 29 / 98$ & 0.2 & 91 & $1 / 22 / 99$ & 9.2 & 7,191 & & & \\
\hline & & & $8 / 3 / 98$ & 0.2 & 90 & & & & & & \\
\hline & & & $8 / 13 / 98$ & 0.7 & 88 & & & & & & \\
\hline & & & $8 / 19 / 98$ & 0.4 & 82 & & & & & & \\
\hline & & & $9 / 17 / 98$ & 0.3 & 72 & & & & & & \\
\hline & & & $10 / 16 / 98$ & 0.4 & 50 & & & & & & \\
\hline & & & $11 / 11 / 98$ & 0.6 & 51 & & & & & & \\
\hline & & & $12 / 15 / 98$ & 0.7 & 47 & & & & & & \\
\hline & & & $1 / 19 / 99$ & 0.8 & 59 & & & & & & \\
\hline
\end{tabular}


Table 7: Results of groundwater sampling - Wells SSM-006 and SSM-007

\begin{tabular}{|c|c|c|c|c|c|c|c|c|c|c|c|}
\hline \multicolumn{3}{|c|}{ SSM-006 B } & \multicolumn{3}{|c|}{ SSM-006 C } & \multicolumn{3}{|c|}{ SSM-007 B } & \multicolumn{3}{|c|}{ SSM-007 C } \\
\hline & D.O. & TCE & & D.O. & TCE & & D.O. & $\overline{T C E}$ & & D.o. & TCE \\
\hline Date & $\mathrm{mg} / \mathrm{L}$ & ppb & Date & $\mathrm{mg} / \mathrm{L}$ & $\mathbf{p p b}$ & Date & $\mathrm{mg} / \mathrm{L}$ & ppb & Date & $\mathrm{mg} / \mathrm{L}$ & ppb \\
\hline $7 / 21 / 97$ & 8.1 & 740 & $7 / 22 / 97$ & 3.1 & 179 & $7 / 21 / 97$ & 6.2 & 237 & $7 / 21 / 97$ & 4.6 & 1,671 \\
\hline $8 / 22 / 97$ & 7.7 & 671 & $8 / 21 / 97$ & 5.5 & 1,428 & $8 / 19 / 97$ & 8.2 & 173 & $8 / 19 / 97$ & 5.8 & 1,935 \\
\hline $8 / 27 / 97$ & 9.6 & 744 & $8 / 27 / 97$ & 6.3 & 1,259 & $8 / 27 / 97$ & 9.7 & 224 & $8 / 27 / 97$ & 7.1 & 1,550 \\
\hline $10 / 8 / 97$ & 8.2 & 599 & $10 / 8 / 97$ & 7.1 & 991 & $10 / 8 / 97$ & 8.9 & 218 & $10 / 8 / 97$ & 6.5 & 1,209 \\
\hline $11 / 5 / 97$ & 9.0 & 597 & $11 / 5 / 97$ & 7.3 & 419 & $11 / 4 / 97$ & 9.0 & 182 & $11 / 4 / 97$ & 6.7 & 1,371 \\
\hline $11 / 20 / 97$ & 9.1 & 495 & $11 / 20 / 97$ & 7.9 & 462 & $11 / 19 / 97$ & 9.4 & 185 & $11 / 19 / 97$ & 7.3 & 1,670 \\
\hline $12 / 11 / 97$ & 9.4 & 1,162 & $12 / 11 / 97$ & 7.4 & 318 & $12 / 10 / 97$ & 9.2 & 190 & $12 / 10 / 97$ & 7.4 & 1,541 \\
\hline $1 / 14 / 98$ & 8.8 & 409 & $1 / 14 / 98$ & 8.8 & 1,012 & $1 / 14 / 98$ & 9.0 & 195 & $1 / 14 / 98$ & 7.4 & 1,512 \\
\hline $2 / 10 / 98$ & 8.4 & 406 & $2 / 12 / 98$ & 9.4 & 1,280 & $2 / 12 / 98$ & 9.1 & 252 & $2 / 12 / 98$ & 7.3 & 1,308 \\
\hline $3 / 3 / 98$ & 9.2 & 465 & $3 / 3 / 98$ & 10.0 & 1,256 & $3 / 4 / 98$ & 9.3 & 335 & $3 / 4 / 98$ & 7.4 & 1,318 \\
\hline $3 / 19 / 98$ & 8.9 & 428 & $3 / 19 / 98$ & 9.1 & 1,403 & $4 / 2 / 98$ & 8.9 & 260 & $4 / 2 / 98$ & 6.6 & 924 \\
\hline $3 / 31 / 98$ & 9.8 & 414 & $4 / 2 / 98$ & 9.2 & 1,269 & $4 / 16 / 98$ & & 204 & $4 / 16 / 98$ & & 777 \\
\hline $4 / 15 / 98$ & 9.3 & 504 & $4 / 16 / 98$ & 9.8 & 1,291 & $5 / 13 / 98$ & 9.9 & 285 & $5 / 13 / 98$ & 7.4 & 779 \\
\hline $5 / 13 / 98$ & 10.0 & 271 & $5 / 13 / 98$ & 10.1 & 1,276 & $6 / 12 / 98$ & 8.2 & 100 & $6 / 12 / 98$ & 7.0 & 509 \\
\hline $6 / 12 / 98$ & 8.2 & 340 & $6 / 12 / 98$ & 8.5 & 1,113 & $7 / 23 / 98$ & 8.3 & 132 & $7 / 22 / 98$ & 6.9 & 491 \\
\hline $7 / 23 / 98$ & 8.6 & 394 & $7 / 23 / 98$ & 9.6 & 1,529 & $8 / 25 / 98$ & 9.2 & 79 & $8 / 25 / 98$ & 7.2 & 420 \\
\hline $8 / 25 / 98$ & 9.0 & 363 & $8 / 25 / 98$ & 9.9 & 877 & $9 / 18 / 98$ & 9.3 & 74 & $9 / 18 / 98$ & 7.1 & 598 \\
\hline $9 / 18 / 98$ & 8.9 & 748 & $9 / 18 / 98$ & 9.9 & 843 & $10 / 16 / 98$ & 9.6 & 103 & $10 / 16 / 98$ & 7.8 & 1,050 \\
\hline $10 / 19 / 98$ & 9.4 & 895 & $10 / 19 / 98$ & 9.2 & 729 & $11 / 11 / 98$ & 9.3 & 129 & $11 / 11 / 98$ & 8.0 & 2,849 \\
\hline $11 / 13 / 98$ & 9.1 & 761 & $11 / 13 / 98$ & 8.6 & 1,406 & $12 / 15 / 98$ & 9.9 & 214 & $12 / 15 / 98$ & 8.9 & 2,409 \\
\hline $12 / 16 / 98$ & 0.0 & 1,057 & $12 / 16 / 98$ & 0.0 & 1,926 & $1 / 21 / 99$ & 9.3 & 215 & $1 / 21 / 99$ & 8.0 & 2,179 \\
\hline $1 / 21 / 99$ & 9.0 & 1,233 & $1 / 21 / 99$ & 9.0 & 2,904 & & & & & & \\
\hline
\end{tabular}

Table 8: Results of groundwater sampling - Wells SSM-008 and SSM-009

\begin{tabular}{|c|c|c|c|c|c|c|c|c|c|c|c|}
\hline \multicolumn{3}{|c|}{ SSM-008 B } & \multicolumn{3}{c|}{ SSM-008 C } & \multicolumn{3}{c|}{ SSM-009 B } & \multicolumn{3}{c|}{ SSM-009 C } \\
\hline & $\mathbf{D . 0}$ & TCE & & $\mathbf{D . 0}$ & TCE & & $\mathbf{D . 0}$ & TCE & & D.0. & TCE \\
\hline Date & $\mathbf{m g}$ / & $\mathbf{p p b}$ & Date & $\mathbf{m g} / \mathbf{1}$ & $\mathbf{p p b}$ & Date & $\mathbf{m g} \boldsymbol{h}$ & $\mathbf{p p b}$ & Date & $\mathbf{m g} / \mathbf{1}$ & $\mathbf{p p b}$ \\
\hline $2 / 13 / 98$ & 4.1 & & $2 / 13 / 98$ & 0.5 & 1,085 & $1 / 15 / 98$ & 4.8 & 7,613 & $1 / 15 / 98$ & 3.2 & 1,259 \\
\hline $3 / 5 / 98$ & 1.2 & 7,909 & $3 / 5 / 98$ & 3.2 & 1,044 & $2 / 13 / 98$ & 3.1 & 4,564 & $2 / 13 / 98$ & 3.7 & 1,187 \\
\hline $4 / 2 / 98$ & 0.9 & 6,233 & $4 / 2 / 98$ & 2.5 & 1,130 & $3 / 5 / 98$ & 2.6 & 2,673 & $3 / 5 / 98$ & 4.8 & 1,272 \\
\hline $4 / 17 / 98$ & 1.8 & 5,312 & $4 / 17 / 98$ & 4.6 & 1,021 & $4 / 2 / 98$ & 2.6 & 1,842 & $4 / 2 / 98$ & 6.4 & 1,308 \\
\hline $5 / 14 / 98$ & 1.9 & 4,328 & $5 / 14 / 98$ & 4.8 & 1,153 & $4 / 17 / 98$ & 3.7 & 1,670 & $4 / 17 / 98$ & 6.3 & 1,274 \\
\hline $6 / 15 / 98$ & 3.3 & & $6 / 15 / 98$ & 6.8 & 1,133 & $5 / 14 / 98$ & 4.2 & 2,140 & $5 / 14 / 98$ & 6.2 & 1,589 \\
\hline $7 / 24 / 98$ & 2.8 & 3,372 & $7 / 24 / 98$ & 5.3 & 1,900 & $6 / 15 / 98$ & 5.4 & 1,109 & $6 / 15 / 98$ & 8.5 & 1,310 \\
\hline $8 / 26 / 98$ & 3.2 & 1,608 & $8 / 26 / 98$ & 4.7 & 1,122 & $7 / 23 / 98$ & 3.8 & 2,012 & $7 / 24 / 98$ & 8.1 & 1,760 \\
\hline $9 / 29 / 98$ & 3.8 & 3,742 & $9 / 28 / 98$ & 4.1 & 1,009 & $8 / 26 / 98$ & 1.9 & 1,129 & $8 / 26 / 98$ & 7.8 & 1,021 \\
\hline $10 / 19 / 98$ & 3.2 & 8,252 & $10 / 19 / 98$ & 4.0 & 1,147 & $9 / 28 / 98$ & 1.3 & 981 & $9 / 28 / 98$ & 6.6 & 966 \\
\hline $11 / 16 / 98$ & 3.2 & 14,864 & $11 / 16 / 98$ & 3.9 & 1,635 & $10 / 19 / 98$ & 2.4 & 1,193 & $10 / 19 / 98$ & 7.4 & 1,128 \\
\hline $12 / 16 / 98$ & 0.0 & 10,309 & $12 / 16 / 98$ & 0.0 & 1,256 & $11 / 16 / 98$ & 3.2 & 3,249 & $11 / 16 / 98$ & 7.1 & 1,460 \\
\hline $1 / 22 / 99$ & 3.9 & 12,950 & $1 / 22 / 99$ & 4.1 & 1,753 & $12 / 16 / 98$ & 0.0 & 3,534 & $12 / 16 / 98$ & 0.0 & 1,436 \\
\hline & & & & & & $1 / 22 / 99$ & 3.3 & 5,781 & $1 / 22 / 99$ & 7.5 & 1,747 \\
\hline
\end{tabular}


Table 9: Results of exhaust air sampling - SSR-012

\begin{tabular}{|c|c|c|c|c|c|c|}
\hline Period & $\begin{array}{c}\text { Inlet } \\
\text { airflow } \\
\text { (cfm) }\end{array}$ & $\begin{array}{c}\text { Exhaust air } \\
\text { conc. } \\
\text { (ppmv } \\
\text { TCE) }\end{array}$ & $\begin{array}{c}\text { Exhaust air } \\
\text { conc. (ppmv } \\
\text { PCE) }\end{array}$ & $\begin{array}{c}\text { Cumulative } \\
\text { lbs. TCE } \\
\text { removed }\end{array}$ & $\begin{array}{c}\text { Cumulative } \\
\text { lbs. PCE } \\
\text { removed }\end{array}$ & Notes \\
\hline Jan-97 & 18 & 1.7 & 0.007 & 0.3 & 0.001 & \\
\hline Feb-97 & 22 & 1.7 & 0.007 & 1.0 & 0.006 & \\
\hline Mar-97 & 30 & 1.2 & 0.024 & 1.9 & 0.020 & \\
\hline Apr-97 & 30 & 1.2 & 0.024 & 7.3 & 0.052 & \\
\hline May-97 & 30 & 55 & 0.400 & 46.2 & 0.265 & 1 \\
\hline Jun-97 & 30 & 56 & 0.400 & 76.8 & 0.517 & \\
\hline Jul-97 & 28 & 75 & 1.500 & 122.5 & 1.276 & \\
\hline Aug-97 & 33 & 81 & 0.670 & 182.7 & 1.690 & \\
\hline Sep-97 & 26 & 55 & 0.150 & 214.6 & 1.783 & 2 \\
\hline Oct-97 & 38 & 50 & 0.450 & 255.6 & 2.067 & \\
\hline Nov-97 & 38 & 52 & 0.540 & 303.8 & 2.537 & \\
\hline Dec-97 & 36 & 78 & 0.950 & 336.8 & 2.871 & 3 \\
\hline Jan-98 & 35 & 78 & 0.950 & 100.9 & 3.497 & \\
\hline Feb-98 & 33 & 76 & 1.100 & 454.0 & 4.129 & \\
\hline Mar-98 & 33 & 72 & 0.730 & 508.0 & 4.582 & \\
\hline Apr-98 & 33 & 64 & 0.650 & 554.2 & 4.973 & \\
\hline May-98 & 33 & 62 & 0.054 & 600.0 & 5.282 & \\
\hline Jun-98 & 33 & 63 & 0.930 & 643.5 & 5.840 & \\
\hline Jul-98 & 33 & 54 & 1.150 & 679.7 & 6.551 & \\
\hline Aug-98 & 31 & 67 & 2.220 & 729.2 & 7.840 & \\
\hline Sep-98 & 0 & NA & NA & 729.2 & 7.840 & 4 \\
\hline Oct-98 & 0 & NA & NA & 729.2 & 7.840 & \\
\hline Nov-98 & 0 & NA & NA & 729.2 & 7.840 & \\
\hline Dec-98 & 0 & NA & NA & 729.2 & 7.840 & \\
\hline Notes:9 & 33 & 53 & & \\
\hline
\end{tabular}

Notes: 1) Well was redeveloped 4/24/97. Air injection submergence $=50.6$ feet.

2) Air injection submergence reduced to 30.6 feet.

3) Air injection submergence returned to 50.6 feet.

4) Well removed from service for upgrades. 